Nova Southeastern University NSUWorks

\title{
Measuring Factors That Influence the Success of E- government Initiatives
}

Ronnie Park

Nova Southeastern University, pronnie@nova.edu

This document is a product of extensive research conducted at the Nova Southeastern University College of Engineering and Computing. For more information on research and degree programs at the NSU College of Engineering and Computing, please click here.

Follow this and additional works at: https://nsuworks.nova.edu/gscis_etd

Part of the Computer Sciences Commons

\section{Share Feedback About This Item}

\section{NSUWorks Citation}

Ronnie Park. 2007. Measuring Factors That Influence the Success of E-government Initiatives. Doctoral dissertation. Nova Southeastern University. Retrieved from NSUWorks, Graduate School of Computer and Information Sciences. (761)

https://nsuworks.nova.edu/gscis_etd/761.

This Dissertation is brought to you by the College of Engineering and Computing at NSUWorks. It has been accepted for inclusion in CEC Theses and Dissertations by an authorized administrator of NSUWorks. For more information, please contact nsuworks@nova.edu. 
Measuring Factors That Influence the Success of E-government Initiatives

by

Ronnie Park

A dissertation report submitted in partial fulfillment of the requirements for the degree of Doctor of Philosophy

in

Information Systems

Graduate School of Computer and Information Sciences

Nova Southeastern University 


\section{Approval/Signature}

We hereby certify that this dissertation, submitted by Ronnie Y. Park, conforms to acceptable standards and is fully adequate in scope and quality to fulfill the dissertation requirements for the degree of Doctor of Philosophy.

Easwar Nyshadham, Ph.D.

Date

Chairperson of Dissertation Committee

Laurie Dringus, Ph.D.

Date

Dissertation Committee Member

Yair Levy, Ph.D.

Date

Dissertation Committee Member

Approved:

Edward Lieblein, Ph.D.

Date

Dean 
An Abstract of a Dissertation Submitted to Nova Southeastern University

in Partial Fulfillment of the Requirements for the Degree of Doctor of Philosophy

\title{
Measuring Factors That Influence the Success of E-government Initiatives
}

\author{
by \\ Ronnie Park
}

March, 2007

The success of e-government initiatives is contingent upon its citizens' willingness to use the services. Citizens are more likely to use e-government services if they believe that they get better value than from the conventional government services. Understanding how citizens value e-government services is critical to the success of these initiatives. This study utilizes two concepts from the field of decision analysis. These are mean-ends chains and value-focused thinking. The research that follows describes the development of a model to identify factors that influence value judgments of citizens.

Based on the data of 210 responses from e-government service users, two instruments were developed to measure perceived e-government value. They were means objectives and fundamental objectives. What is important to e-government users are the fundamental objectives. Means objectives help to achieve the fundamental objectives. The study results suggested a 4-factor 20-item instrument that measures means objectives in terms of public trust, information access, public accessibility, and quality of services. The results also suggested a 4-factor 18-item instrument that measures fundamental objectives in terms of time savings, efficiency of service, service to citizen, and social awareness. The study also showed evidence of content validity, construct validity, and reliability. 


\section{Acknowledgements}

I have been blessed to work with and learn from many people who have supported my research effort. First, my advisor, Dr. Easwar Nyshadham, who guided me in the completion of this project as well as making a great contribution to my personal

development as a researcher. Thanks also to my committee members, Dr. Laurie Dringus, and Dr. Yair Levy, for their time, their talent, and their help.

I wish to thank Midori, Kenn, and Nelson who helped with proofreading and editing this paper. I am very grateful to the people who helped by participating in the surveys. Finally, I would like to thank my wife, Insook, and my family members for their understanding and emotional support during the long journey of this effort. 


\section{Table of Contents}
Abstract iii
Acknowledgements iv
List of Tables vii
List of Figures viii

\section{Chapters}

\section{Introduction 1}

Background 1

Problem Statement and Goal 2

Relevance and Significance 4

Definition of Terms 8

Summary 11

\section{Review of Literature 12}

Decision Analysis 12

E-government Strategy 17

Stages of E-government Transformation 22

Similarities Between E-government and E-commerce 25

Differences Between E-government and E-commerce 28

E-government Measurement Criteria 30

Value Theory (Value-Focused Thinking Approach) 35

Means Objectives and Fundamental Objectives 37

Derivation of E-government Value From Technology 39

\section{Methodology 42}

Introduction 42

Scope Definition 43

Procedures 44

Generating a List of E-government Objectives and Classifying Them as Means and Fundamental Types 44

Extracting E-government objectives From the Internet Commerce Study 46 Extracting E-government Objectives From the E-government Research Pool 46

Combining E-government Objectives From the Internet Commerce Study and the E-government Research Pool 54

Conducting Survey and Data Analysis 57

Design of Case Study 57

Type of Investigation 58

Extent of Researcher Interference 58

Measurement 58

Instrument Validation 60

Content Validity 61

Construct Validity 61 


\section{Reliability 62 \\ Use of Factor Analysis 63 \\ Data Collection 65 \\ Ethics in Data Collection 68 \\ Time Horizon 69 \\ Unit of Analysis 69}

Relating the Means and Ends Factors by Examining the Cross-correlations

Among Factors 70

Resources 70

Limitations and Barriers 70

Summary 73

\section{Results 75}

Data Analysis for Means Objectives 75

Descriptive Statistics 75

Item Purification and Reliability Test 78

Dimensionality 81

Factor Analysis (Principal Component analysis) 82

Findings 90

Data Analysis for Fundamental Objectives 92

Descriptive Statistics 92

Item Purification and Reliability Test 94

Dimensionality 96

Factor analysis (Principal Component analysis) 97

Findings 104

Relating the Means and Ends Factors 106

Summary of Results 108

5. Conclusions, Implications, Recommendations, and Summary 110

Conclusions 110

Implications 112

Recommendations 113

Summary 114

\section{Appendixes}

A. Measures of Factors That Influence Internet Commerce Success 121

B. E-government Relevant Factors 124

C. The Functional Performance Dimensions That Reflect the Common Municipality Functions and Services That Can Be Web-enabled 130

D. Survey Instrument 131

E. Research Pool From Which E-government Values Are Drawn 136

F. NSU IRB Approval Letter 137

G. Survey Instrument Sample Screen 138

\section{References 139}




\section{List of Tables}

1. Definition of Terms 8

2. Barriers to the Success of E-government Initiatives, and Actions for Overcoming Them 21

3. The Stages of E-government Transformation 23

4. The Dimensions of E-government Transformation 24

5. Measuring Organizational Performance 43

6. E-government Objective Items With the Categorized E-government General Objectives: Means Objectives (MO) and Ends Objectives (EO) 49

7. Means Objectives for E-government Services 54

8. Fundamental Objectives for E-government Services 56

9. Descriptive Statistics for Means Objectives 75

10. Item-Total Statistics for Means Objectives 78

11. Communalities for Means Objectives 83

12. Factor Pattern for Measures of Means Objectives 91

13. Descriptive Statistics for Fundamental Objectives 93

14. Item-Total Statistics for Fundamental Objectives 95

15. Communalities for Fundamental Objectives 98

16. Factor Pattern for Measures of Fundamental Objectives 105

17. Correlations Among Constructs 107

18. Measures of Means Objectives 117

19. Measures of Fundamental Objectives 118 


\section{List of Figures}

1. Steps for Instrument Development 43

2. E-government Value Extracting Process 45

3. Questions and References for the Validities 60

4. Sample Survey Layout 67

5. KMO and Bartlett's Test for Means Objectives 82

6. Total Variance Explained for Means Objectives 86

7. Scree Plot for Means Objectives 87

8. Component Plot in Rotated Space for Means Objectives 88

9. Component Loadings for Rotation Solution for Means Objectives 89

10. KMO and Bartlett's Test for Fundamental Objectives 97

11. Total Variance Explained for Fundamental Objectives 100

12. Scree Plot for Fundamental Objectives 101

13. Component Plot in Rotated Space for Fundamental Objectives 102

14. Component Loadings for Rotation Solution for Fundamental Objectives 103 


\section{Chapter 1}

\section{Introduction}

\section{Background}

As Information Systems (IS) evolve, government agencies search for better ways to operate and provide improved services to the public through its use (West, 2004). IS is being applied vigorously by government units at national, regional, and local levels around the world (Marchionini, Samet, \& Brandt, 2003). In the 1990s, the advent of network-based IS, represented a turning point in the strategic direction for government agencies, which now had the opportunity to utilize e-commerce to achieve their objectives (Kalakota \& Whinston, 1997) through e-government.

E-government is narrowly defined as "the delivery of government information and services online through the Internet or other digital means" (West, 2004, p. 2). The principles of e-government embrace building services around citizens' choices, improving accessibility to government and its services, facilitating social inclusion, presenting information responsibly, and using government resources effectively and efficiently (Office of the e-Envoy, 2000). E-government can be viewed as (a) transformation of the business of governance, i.e. improving service, and renewing administrative processes, and (b) transformation of governance itself, i.e. re-examining the functioning of democratic practices and processes (Aichholzer \& Schmitzer, 2000). E-government can be thought of as a conceptual lens through which the changing role and shape of the public sector in the $21^{\text {st }}$ century can be examined. It is expected to be 
more digital, knowledge-intensive, driven by innovation, and interdependent than any previous time (Roy, 2003).

\section{Problem Statement and Goal}

Governments are employing network-based IS in the expectation that it will be cheaper, faster, and more convenient than traditional means of delivering products and services (McNeal, Tolbert, Mossberger, \& Dotterweich, 2003). Having invested an enormous amount of resources in e-government (Peters, Jansen, \& Engers, 2004), governments strive to succeed in this endeavor. To achieve the success of e-government, it is critical to understand and influence citizens' acceptance of e-government services (Fu, Farn, \& Chao, 2006) because the success of e-government initiatives is contingent upon citizens' willingness to use these services (Carter \& Belanger, 2005; Devadoss, Pan, \& Huang, 2002). The addressable problem of this dissertation study is that it is not clear whether citizens will embrace the use of such services (Carter \& Belanger, 2004). As values are the basic principles that guide actions and preferences (Keeney, 1992), citizens are likely to use such services if they feel that they get better value than from the conventional government services. Thus, e-government value to citizens is an important factor for the success of e-government. The broad goal of this research was to explore egovernment values from citizens' perspectives. From the broad goal, the two main goals of this research were:

1. Conceptualize the value of e-government.

2. Develop two instruments to measure factors that influence the success of egovernment initiatives - ends objectives and means objectives. 
The specific research question being addressed in this study was "What do citizens value most in e-government services?" The research question was measured by a case study that collected e-government values from citizens via online Web surveys. The collected data reflected what citizens value most when they engage with e-government service.

To address the goals of this research, the combined research methodology of literature research and a case study were chosen. Literature research was used to explore e-government values from the leading refereed literature covering the 6-year period from 2000 to 2005 . A case study methodology was used to collect perceived e-government values from e-government users based on the approach by Keeney (1999), and Torkzadeh and Dhillon (2002).

Numerous studies have analyzed success factors of e-commerce. Yet to date, no study has identified the success factors of e-government (Carter \& Belanger, 2004) that focuses on value specially. In this research, a model of factors that influence the success of e-government initiatives was developed based on the "Value-focused" thinking approach by Keeney (1999), as well as exploratory studies on the value of Internet commerce to the customer by Torkzadeh and Dhillon (2002). This research used the means-ends analysis and Keeney's "Value-focused" thinking to study the perception of value from the point of view of e-government users. Survey data were used to develop two instruments: one for understanding means (means objectives); and a second for understanding ends (fundamental objectives). The value includes benefits and prices of the services, benefits and costs of ordering and receiving services (e.g., reduced effort), and possible benefits and costs to the world (e.g., environmental impacts). 
Keeney (1992) suggested that the value-focused thinking approach be used to design Web-based businesses for business-to-consumer commerce. In his preliminary study, he identified 91 objectives for Internet commerce, grouped into 25 categories, 16 of which are classified as means objectives, and the rest are fundamental objectives. Torkzadeh and Dhillon (2002) followed up on Keeney's work with a more comprehensive data collection effort and derived a more complete set of means and ends objectives in a business to consumer ecommerce context. They generated 125 objectives (value items) that influence Internet commerce success. A similar effort to derive objectives in an e-government context is lacking. This dissertation applied the approach developed by Keeney and used later by Torkzadeh and Dhillon in a business-to-consumer (B2C) context to a government-to-citizen (G2C) context. Several new objectives appropriate for an e-government context were generated, based on existing research on egovernment. Most of the existing e-government studies are not empirical but rhetoric in nature (Norrise \& Moon, 2005; Devadoss et al., 2002). This research conducted an empirical study.

\section{Relevance and Significance}

Given that more government entities invest heavily in e-government, egovernment has become an evolving and important research area in the IS field (Chen, Chen, Huang, \& Ching, 2006). One of the e-government areas worthy of research is to clarify how the success of e-government can be measured (Peters et al., 2004). This research develops instruments to measure the factors that influence the success of egovernment initiatives based on e-government value. 
The theoretical foundation for this research comes from two concepts, which are well known in Decision Analysis. Decision Analysis (Winterfeldt \& Edwards, 1986) is a field in business which seeks to improve human decision making by developing new concepts, theories, and tools. One of the concepts of Decision Analysis is means-ends analysis. Means-ends analysis is a problem solving strategy that attempts to search and apply an action (means) to achieve a goal (ends). First, it compares the current state and the goal state to identify the differences between them. Then, it applies the appropriate action to reduce the differences. The means is the activity to achieve the ends. A second concept from Decision Analysis is the notion of value, as discussed by Keeney in valuefocused thinking. The value-focused approach stresses that values are fundamentally important in any decision situation, while alternatives are relevant only because they are a means to achieve the desired values. Thus, the thinking should focus first on values and later on alternatives that might achieve them. Value-focused thinking, therefore, asks the most important question: what do people really value in a given situation? (Keeney, 1992). The two concepts of means-ends chain and value-focused thinking are closely related. This study proposed a framework for the notion of e-government value using these two concepts, which can be illustrated using a simple example. Suppose a decisionmaker, such as an e-government consumer, is faced with a choice between two alternatives, each of the alternatives is characterized by several attributes. One is tempted to ask the question: which alternative is better? However, if one is using a means-ends chain, one must ask two questions. What do I want? (ends). And how do I get what I want? (means). Keeney calls ends "Fundamental Objectives", and means "Means Objectives". In the context of an e-commerce purchase, online security gives the 
customer the confidence to make use of the innate convenience of e-commerce.

Convenience is an ends objective. Online security and confidence are means objectives. Ends (end objectives) follow means (means objectives). A second aspect of Keeney's value-focused thinking approach is that, instead of focusing on alternatives, it focuses on attributes of the alternatives. Some attributes characterize the means dimension and therefore, are called means objectives; others characterize the ends and are called fundamental objectives. That is, objectives are expressed as a suitably weighted combination of attributes of alternatives. Therefore, to understand which alternative is better, a decision maker considers the attributes, and weights their importance.

The following example is used to explain decision analysis approach and the definition of several terms that will be used throughout the dissertation. Assume that, in the previous example, an e-government user has identified the attributes of the alternatives. The user's model for judging the value of an alternative may be written down as:

Overall value of alternative $=\mathrm{f}($ Attributes of the e-government service $)$ Under further assumptions, the following multi-attribute model can be used to evaluate the user's judgments:

Overall value $=\sum\left(\mathrm{w}_{\mathrm{i}}^{*} \mathrm{x}_{\mathrm{i}}\right)$, where $\mathrm{Wi}_{\mathrm{i}}=$ weight $/$ importance of the attribute $\mathrm{x}_{\mathrm{i}}=$ level of the attribute

In this dissertation, the word value (in italics) refers to overall value of the alternative, and value of attribute $\mathrm{i}$ to refer to the $\mathrm{w}_{\mathrm{i}}{ }^{*} \mathrm{x}_{\mathrm{i}}$. Attributes can be broken down further (e.g., $\mathrm{x}_{\mathrm{i}}$ can be composed of several sub-attributes such as $\mathrm{x}_{\mathrm{i} 1}, \mathrm{x}_{\mathrm{i} 2}$ etc.) and these 
are referred to as value items. Table 1 summarizes the terminology. The above multiattribute model can be presented with the e-government example as:

Overall e-government value $=\sum\left(\mathrm{w}_{\mathrm{i}}{ }^{*} \mathrm{x}_{\mathrm{i}}\right)$, where $\mathrm{i}=$ attribute (e.g., online convenience)

$\mathrm{w}_{\mathrm{i}}=$ the weight attached to an attribute(e.g., a subject weights online convenience as 0.4 , and, say, ease of use as 0.7 .)

$\mathrm{x}_{\mathrm{i}}=$ the score of an attribute (e.g., a subject scores attributes as 4 on online convenience from an e-government service on a Liker scale of 1 to 5.) value $(\mathrm{i})=$ value of an attribute $=\mathrm{w}_{\mathrm{i}}{ }^{*} \mathrm{x}_{\mathrm{i}}$ (e.g., value of online convenience to citizen is $0.4 * 4=1.6$ units)

Value $=$ Sum of individual values $=\sum\left(\mathrm{w}_{\mathrm{i}}{ }^{*} \mathrm{x}_{\mathrm{i}}\right)(\mathrm{e} . \mathrm{g}$., a subject uses 0.4 and 0.6 as weights for online convenience and ease of use, and scores alternatives as 4 on online convenience and 5 on ease of use. Then the value $=0.4 * 4+0.6 * 5=4.6$ units).

Using these concepts, one can provide systematic advice in terms of what a person wants (fundamental objectives or values) and how one achieves value (means objectives or values). Two instruments were developed, one measures means objectives and the other measures ends objectives.

These instruments can help an e-government researcher specify and test specific theories of e-government value. More importantly, they can assist practitioners in assessing whether their current e-government projects are providing value to users. The instruments can also be used to proactively assess whether a prototype e-government project can be a success. The approach used in this dissertation is general, and new 
instruments may be designed for different contexts or domains, using the same methodology adopted in this dissertation.

The first stage in instrument development involved generating a list of items that reflect e-government value to citizens and conducting a survey to collect data that reflect what citizens value. Activities in this stage included extracting e-government values from literature review and grouping them into the means and ends types based on the means-ends analysis used by Keeney (1999). A survey questionnaire was developed for each item using a 5-point Likert scale to indicate the level of significance. Then a survey was conducted to gather data for each type.

The second stage was to conduct independent analysis for each type of item for item purification and to generate means objectives and end objectives. Activities included eliminating items, using the corrected item-total correlation and Cronbach's $\alpha$ and further purifying items in order to produce two simple factor models, one for each type of objectives, using an exploratory factor analysis.

Table 1

Definition of Terms

Term Definition

Alternatives

The means to achieve the goal. The attributes of the alternatives relevant to the choice lead to decision.

Attributes/Characteristics Measure of effectiveness, measure of performance, and criterion. Used to measure the degree to which an objective is achieved (Keeney \& Raiffa, 1993). 
Table 1 (continued)

Term

Ends objectives

Fundamental objectives

Means objectives

Means-ends analysis

Objective

Value

\section{Definition}

The goal state achieved by the means objectives in the means-ends relationship. Regarded as fundamental objectives in the value-focused thinking approach. The ends objectives achieved by the means objectives. Characterized as an essential reason for interest in the decision context, which defines the consequences of concern (Keeney, 1992).

The ways to achieve the ends (fundamental) objectives. Help to achieve one or more of the other objectives. Problem-solving strategy that attempts to apply an action (means) to achieve a goal (ends). First, it compares the current state and the goal state to identify the differences between them. Then, it applies the appropriate action to reduce the differences.

A statement of something that one desires to achieve (Keeney, 1992). Expressed as a suitably weighted combination of attributes of alternatives. Weighted average of values. The basic principle that guides actions and preferences (Keeney, 1992). 
Table 1 (continued)

Term Definition

Values

Weight placed on attributes. "Values are abstractions that help organize and guide preferences... expressed as statement of desired states, positive intentions, or preferred directions" (Winterfeldt \& Edwards, 1986, p. 38).

Value-focused thinking A decision analysis method that emphasizes values that are fundamentally important in any decision situation. It holds that alternatives are relevant only because they are a means to achieve the values (Keeney, 1999).

Value items The specific items used in operational instruments for measuring values.

Weights Factors assigned to an alternative that reflects its importance (Keeney, 1992). Assigned to a number in a computation, as in determining an average, to make the number's effect on the computation reflect its importance. 


\section{Summary}

In this chapter, the background information about e-government, problem statement and goal, and relevance and significance of this study was addressed. E-government initiatives are in place or underway in most countries to provide better government services. Measuring the success of such efforts requires an instrument that can capture the perceived value that citizens expect from e-government. The focus of this research was to demonstrate procedures for developing such an instrument. The theoretical foundation was grounded on two concepts; the means-ends analysis, and value-focused thinking approach developed by Keeney (1992) in the decision analysis field. The goal of this study was to conceptualize the value of egovernment, and to develop two instruments to measure factors that influence the success of e-government initiatives - ends objectives and means objectives.

The development of the instrument began with generating a list of items that reflect e-government value to citizens for literature review and grouping them into the means and ends types. Then a survey was conducted to collect data for each type. Independent analysis was conducted on these items for item purification using factor analysis and generated two models of factors: one for means objectives, and the other for end objectives. 


\section{Chapter 2}

\section{Review of Literature}

This section starts with a discussion of the value theory in the field of decision analysis and explores its implications for decision-making as the theoretical foundation of this study. Next, e-government strategies, stages of e-government transformation, and the differences and similarities between e-government and e-commerce are discussed to clarify the concept and progress of e-government initiatives. Then, the e-government measurement criteria with the implied success factors and values developed in prior egovernment research are addressed, as they provide the foundation for guiding this study. At the end, this study discusses the value-focused thinking theory (Keeney, 1999) along with its implications for the fields of e-commerce and e-government.

\section{Decision Analysis}

Choosing a course of action in a world of uncertainty is a chore that all people must perform. Most of these choices are made without careful analysis but there are those situations where a more systematic way to arrive at a decision would be preferred (Raiffa, 1968). Today's decision makers are faced with problems characterized by increasing demands upon a limited resource base; increasing complexity resulting from the interacting of biophysical, socio-economic, and institutional systems; and increasing awareness of the uncertainty that pervades the understanding of these systems. The decision-making context is further complicated by the now commonplace necessity to 
involve multiple stakeholders and their multiple objectives in the decision-making process. Under these complex and dynamic circumstances, a structured approach to decision making supported by appropriate analytical tools is imperative if good decisions are to be made (Ohison, 1999).

Winterfeldt and Edwards (1986) posited that many different models used in helping people make decisions can be distinguished by their topics and by whether they are descriptive or normative. The topics include modeling people's behavior, modeling the environments in which people act, and modeling the tasks people face in these environments. Descriptive models describe people, environments, or tasks; normative models prescribe actions for people (or machines) in tasks and specify conditions that environments should attain.

A descriptive model attempts to predict what people do do; a descriptive model of decision-making predicts which decision one in fact will make. Almost all of the familiar psychological models or theories are descriptive. The set of descriptive decisiontheoretic models is called behavioral decision theory (BDT) (Winterfeldt \& Edwards, 1986). The original contributions to BDT were simply empirical anomalies, showing where the expected utility theory made predictions about behavior that were systematically wrong (Thaler, 1986). Kahneman and Tversky (1979), and Einhorn and Hogarth (1981) had taken these anomalies and developed descriptive theories that account for the observed behavior. These explicitly descriptive theories can not be derived from normative axioms (Thaler, 1986). Behavioral decision research is concerned with how people make judgments and choices, and with how the processes of decision might be improved (Einhorn \& Hogarth, 1981). The field of behavioral decision 
research is intensely interdisciplinary, applying concepts and methodologies from psychology, economics, statistics, and other disciplines, that has had an impact on various areas, such as economics (Robin, 1998, Kahneman \& Tversky, 1979), finance (Thaler, 1987), and game theory (Camerer, 1997).

At present, behavioral economics is one of the most active fields in economics, building a bridge between research in economics and psychology around experimental methods and theoretical modeling (Vetenskapsakademien, 2002). Psychology systematically explores human judgment, behavior, and well-being that can teach us important facts about how humans differ from the way they are traditionally described by economists (Robin, 1998). Economics has conventionally assumed that each individual has stable and coherent preferences, and that she rationally maximizes those preferences. Given a set of options and probabilistic core beliefs, a person is assumed to maximize the expected value of a utility function (Robin, 1998). Psychological research suggests various modifications to this conception of human choice (Robin, 1998). In psychology, especially cognitive psychology, a human being is commonly regarded as a system, which does and interprets available information in a conscious and rational way. But other, less conscious, factors are also assumed to govern human behavior in a systematic way. This more complex view - where intrinsic incentives help shape human behavior has come to penetrate recent developments in economic theory (Vetenskapsakademien, 2002). Kahneman and Tversky (1979) have used insights from cognitive psychology regarding the mental processes for forming judgements and choices to understand how people make economic decisions. Behavioral finance also derived from the psychological study of human decision making, in contrary to the standard assumptions 
underlying investment forecasting and portfolio management, takes into account the emotional and psychological biases of the investment decisions - anomalies. For example, Thaler (1987) presented the anomalies from the seasonal movements in security prices in January, reflecting that the standard economic paradigm - rational agents in an efficient market - does not adequately describe behavior in financial market. He posited that the January effect based on the argument that the prices of firms which have previously declined in price will decline further in the latter months of the year as owners sell off the shares to realize capital losses is not derived from rational behavior by all market participants. Behavioral game theory uses psychological principles and experiments to describe and help predict strategic behavior that takes the experimental science of behavioral economics a major step forward. Behavioral game theory aims to replace descriptively inaccurate modeling principles with more psychologically reasonable ones, expressed as parsimoniously and formally as possible. The desire to improve descriptive accuracy that guides behavioral game theory does not mean game theory is always wrong (Camerer, 1997). Standard equilibrium analyses assume all players: 1) form beliefs based on analysis of what others might do (strategic thinking); 2) choose a best response given those beliefs (optimization); 3) adjust best responses and beliefs until they are mutually consistent (equilibrium) (Camerer, Ho, \& Chong, 2001). It is widely accepted that not every player behaves rationally in complex situations as player's fates are intertwined, so assumptions (1) and (2) are sometimes violated. It is also unlikely that equilibrium (3) is reached instantaneously in one-shot games (Camerer et al, 2001). 
A normative model or theory is a set of rules specifying what individuals or groups should do. A normative model for decision making, then, specifies what decisions one should make. The set of normative decision-theoretic models together with the techniques for applying them are usually called decision analysis (DA) (Winterfeldt \& Edwards, 1986). The research carried out in DA has generated a considerable amount of literature on understanding and improving decision making of individuals, groups, and organizations. It is generally considered a branch of the engineering discipline of operations research but also has links to economics, mathematics, psychology (Bichler, 2000), and business and management. Furthermore, among other disciplines, DA contributed to IS research.

Central to normative theories are the concepts of rationality and optimality (Einhorn \& Hogarth, 1981) that presents cleaner results. This study is based on DA rather than BDT. DA looks at the paradigm in which an individual decision maker (or decision unit) contemplates a choice of action in an uncertain environment. The approach employs systematic analysis, with some number pushing, which helps the decision maker clarify in his own mind which course of action he should choose (Keeney \& Raiffa, 1993). Howard (1988) stated that the discipline of DA represents a systematic procedure for transforming opaque decision problems into transparent decision problems by a sequence of transparent steps. "Opaque means "hard to understand, solve, or explain; not simple, clear, or lucid' and transparent means 'readily understood, clear, obvious' "(Howard, 1988, p. 680). In other words, DA offers the decision-maker the possibility of replacing confusion with clear insight for a desired course of action (Howard, 1988). 
Values pervaded in the field of operation research are expressed as objectives, goals, criteria, performance measures, weights, preferences, and/or objective functions; they are necessary in theoretical operations-research models and in applications (Keeney, 1992). The focus of the study was on values expressed as objectives. Though values are clarified with an explicit statement of specific objectives, identifying and structuring objectives is a difficult task: ends are often confused with means, and objectives with targets or constraints or even alternatives; the relationships among objectives are unclear; and the concept of priorities within objectives is easily misconstrued (Keeney, 1992). Keeney claimed that the process of developing clear objectives requires greater depth, clear structure, and a sound conceptual base.

Though DA is often boiled down to a set of quantitative techniques for analyzing alternatives associated with complex decision problems, the qualitative aspects of the DA approach may also have significant relevance. For the qualitative approach, Keeney $(1992,1999)$ emphasizes the importance of concentrating on decision makers' values. Values are the basic principles that guide actions and preferences (Keeney, 1992). Developing a clear understanding of values is essential for properly defining decision situations, articulating objectives, and creating and evaluating alternatives. Values are what drive decision makers' preferences for different outcomes. Only after the front-end analysis is complete will the quantitative tools and techniques of more traditional DA be useful in supporting the analysis and selection of appropriate alternatives. 


\section{E-government Strategy}

As e-government initiatives are pervasive at all levels of governments around the world, strategic agendas vary because each vision is driven by its own unique set of social, political, and economic factors and requirements. A key factor driving the achievement of any e-government program is the vision of e-government, articulated and adopted by a government administration (Grant \& Chau, 2005). The mission and objectives that emanate from these e-government visions variously manifest strong focus on one or two elements. For example, the United States has placed a major focus on service delivery and on increasing cross-functional efficiencies (U.S. Office of Management and Budget, 2002) whereas the Malaysian government concentrates on the exposure and outreach area (Grant \& Chau, 2005). The South African government's egovernment program is heavily weighted towards service delivery, while e-government efforts in the United Kingdom have tended to balance several strategic objectives. Egovernment in China attempts to bring economic development through administrative reform (Ma, Chung, \& Thorson, 2005) while e-government in Korea is to enhance the national competitiveness by increasing productivity and transparency (National Computerization Agency, 2002). This section primarily focuses on e-government service as that is the purpose of this study.

E-government services can be largely viewed as providing access to information, transaction services, and citizen participation. Traditional modes of accessing information are much like viewing highway billboards; that is, static mechanisms to display information, such as reports and publications. There is little opportunity for the public to interact with government. Transaction services allow the public to order and 
execute services online, which offers considerable convenience. These types of services require emphases on the public's privacy and security concerns, such as posting privacy policies online, and implementing security features for preventing unauthorized access and protecting property. The citizen participation feature enables government Web sites to move beyond a service-delivery model to system-wide political transformation, such as providing e-forums. The Public Electronic Network (PEN) in the City of Santa Monica is one of the most innovative attempts to provide e-forums. It helps citizens to take advantage of the interactive strengths of the Internet through which democratic responsiveness and leadership accountability can be boosted (West, 2004). Different types of applications will, over time, surely alter the way that citizens interact with governments and will change the work that government agencies do. It has been recognized that the transformation from traditional government to electronic government is one of the most important public policy issues (National Academy of Sciences, 2002).

Analogous to what the private market has seen in the new economy with the diffusion of e-business in almost all forms (e-commerce, online trading, e-banking, einsurance, e-finance, e-payment, e-brokerage, e-procurement), e-government has been conceived as a tool to define and manage the relationships between citizens and the government and among governments through detailed and capillary services, such as digital signatures and e-procurement document management (Fugini \& Mezzazanica, 2004)

The e-government strategy of the U.S. Federal government (1999) promotes access to government information organized not by agency, but by the type of service or information people may be seeking. The data should be identified and organized in a 
way that makes it easier for the public to find the information it seeks, and make a broad range of benefits and services available though private and secure use of the Internet.

The strategy focuses on achieving customer satisfaction.

E-government provides many opportunities to improve the quality of service to the citizen-centered groups by transforming delivery of services. The focuses are (U.S. Office of Management and Budget, 2002):

1. Individuals/Citizens: Government-to-Citizens (G2C). Build easy-to-find, easy-to-use, one-stop points-of-service that make it easy for citizens to access high-quality government services.

2. Business: Government-to-Business (G2B). Reduce government's burden on business by eliminating the redundant collection of data and better leverage e-business technologies for communication.

3. Intergovernmental: Government-to-Government (G2G). Make it easier for states and localities to meet reporting requirements and participate as full partners with the federal government in citizen services, while enabling better performance measurement, especially for grants. Other levels of government will see significant administrative savings and will be able to improve program delivery because more accurate data is available in a timely fashion.

4. Intra-governmental: Internal Efficiency and Effectiveness (IEE). Make better use of modern technology to reduce costs and improve the quality of government agency administration by using industry best practices in areas such as supply-chain management, financial management, and knowledge management.

E-government initiatives must overcome numerous barriers before they can bear fruit. Kappelman, Koh, Prybutok, and Sanchez (2003) posit that these barriers might be technical, organizational, social, cultural, and psychological in nature. Effective communication among all stakeholders is essential for a successful e-government initiative to overcome these barriers. Successful e-government requires establishing proper communication channels to share and collaborate the vision, values, and expectations of the community among all stakeholders (Kappelman et al, 2003). 
The task force of the U.S. Office of Management and Budget (2002) identified key barriers that may prevent the successful implementation of e-government initiatives. Recurring barriers include agency culture, lack of architecture, trust, and resources, and stakeholder resistance. The following table lists these barriers and actions for overcoming them. As the actions (mitigation) are solutions to the problems (barriers), implementing the solutions would contribute to the success of e-government initiatives. Thus, they serve the focus of this study.

Table 2

Barriers to the Success of E-government Initiatives, and Actions for Overcoming Them

Barrier Mitigation

Agency Culture Sustain high level of leadership and commitment.

Establish interagency governance structure.

Give priority to cross-agency work.

Engage interagency user/stakeholder groups, including communities of practice.

Lack of Architecture Lead government-side business and data-architecture rationalization.

Sponsor architecture development for cross-agency projects.

The home page will be the primary online delivery portal for $\mathrm{G} 2 \mathrm{C}$ and $\mathrm{G} 2 \mathrm{~B}$ interactions.

Trust

Through e-authentication e-government initiatives, establish secure transactions and identify authentications that will be used by all e-government initiatives. 
Table 2 (continued)

\begin{tabular}{ll}
\hline Barrier & \multicolumn{1}{c}{ Mitigation } \\
\hline & $\begin{array}{l}\text { Incorporate security and privacy protections into each } \\
\text { business plan. } \\
\text { Provide public training and promotion. }\end{array}$ \\
Mitigation Resources & $\begin{array}{l}\text { Move resources to programs with the greatest return and } \\
\text { citizen impact. }\end{array}$ \\
Set measures up front and monitor implementation. \\
Provide online training to create new expertise among \\
employees and contractors. \\
Create comprehensive strategy for engaging authorities. \\
Have multiple agency members argue collectively for \\
initiatives. \\
Tie performance evaluations to cross-agency success. \\
Communicate strategy to stakeholders.
\end{tabular}

\section{Stages of E-government Transformation}

As researching the progress of e-government initiatives in order to understand the e-government phenomena is a major objective of this study, two examples are presented: the stage and dimension approaches. Since the mid-1900s governments around the world have been executing major initiatives in order to tap the vast potential of the Internet for improving and perfecting the governing process. In an effort to gain an appreciation of the global e-government landscape in 2001, the American Society for Public 
Administration (ASPA) and the United Nations Division for Public Economics and Public Administration (UNDPEPA) undertook a research study analyzing the progress on the part of the 190 UN member states. National government Web sites were analyzed for the content and services available that the average citizen would most likely use. The presence or absence of specific features contributed to determining a country's level of progress. Table 3 lists the progressive stages that present a benchmark which assesses a country's online sophistication, reflecting e-government transformation by the UN (2002): emerging, enhanced, interactive, transactional, and seamless. This effort concluded that national e-government program development remains overwhelmingly at the information provision stages. In 2001, of the $190 \mathrm{UN}$ member states, $169(88.9 \%)$ of their national governments used the Internet in some capacity to deliver information and services. The highest number (34.2\%) among the member states were in the enhanced stage and the lowest number $(9 \%)$ were in the transactional stage.

Table 3

The Stages of E-government Transformation (United Nation, 2002)

Stages

Description

Emerging An official government online presence is established.

Enhanced Government sites increase; information becomes more dynamic.

Interactive $\quad$ Users can download forms and interact through the Web.

Transactional Users can actually pay for services and other transactions online.

Seamless Full integration of e-services across administrative boundaries. 
The United Nations report (2002) concluded that a country's social, political, and economic composition correlates closely with its e-government program development. However, there were exceptions, as evidenced by several developing and transitioning economies. Key factors such as the state of a country's telecommunications infrastructure, the strength of its human capital, the political will and commitment of the national leadership, and shifting policy and administrative priorities play important roles. Each of these factors influences how decision makers, policy planners, and public-sector managers elect to approach, develop, and implement e-government programs.

E-government transforms the business of governance, such as improving service and governance itself, and re-examining the functions of democratic practices. Navarra \& Cornford (2003) identify four dimensions of this e-government transformation in Table 4 (Navarra \& Cornford, 2003):

Table 4

The Dimensions of E-government Transformation (Navarra \& Cornford, 2003)

Dimension

Description

Private sector

To reduce costs by improving the functioning of market mechanisms so as to increase transparency in contractual relationships, and to transform government agencies into selfgoverning organizations with more freedom of decision making and responsibility over the allocation of resources.

Civil society To create an efficient information and communication technology infrastructure that facilitates the networking of the region so that institutions of civil society and other non-government organizations can be trusted to provide some government services 
Table 4 (continued)

Dimension

Description

without problems of incompatibility. These organizations are based on their potential for responsive service delivery.

Interactive The potential for inter-government communication in the future will be enhanced. For instance, intelligence could be more easily shared between governments to fight crime, as well as to support services such as health care for an increasingly mobile population.

Role of government E-government potentially can re-shape the business of governance by moving forward a pluralistic government model which is able to steer all members of society by effective regulation. The promise of more direct participation in policy-making as a way to create more effective democratic processes is at the core of many government efforts.

\section{Similarities Between E-government and E-commerce}

E-government is one of most interesting concepts introduced in the field of public administration in the late 1990s. Like many managerial concepts and practices in public administration (TQM, strategic management, participative management, etc.), the idea of e-government followed private sector adoption of e-commerce (Moon, 2002).

E-government and e-commerce (also called Internet commerce in this paper) are similar in nature in that e-commerce models can be used to study electronic services in the public sector (Carter \& Belandger, 2004). Both e-government and e-commerce are based on Internet technology designed to facilitate the exchange of goods, services, and information between two or more parties (Carter \& Belanger, 2004) by sharing the same characteristics: paperless, timeless, and borderless (Schubert \& Hausler, 2001). 
Governments provide goods and services to citizens the same way e-commerce provides those things for them as consumers; thus, e-commerce may provide a useful role model for e-government (Stahl, 2002). In general, there are two major types of e-commerce: business-to-consumer (B2C) and business-to-business (B2B). In B2C transactions, online transactions are made between businesses and individual consumers, such as when airlines sell tickets to travelers; whereas in B2B transactions, businesses make online transactions with other businesses, such as when businesses purchase parts, fuel, or services online (King, Lee, Warkentin, \& Chung, 2002). Comparable categories for egovernment services are government-to-citizen (G2C), government-to-business (G2B), and government-to-government $(\mathrm{G} 2 \mathrm{G})$. $\mathrm{G} 2 \mathrm{C}$ and $\mathrm{G} 2 \mathrm{~B}$ are similar to $\mathrm{B} 2 \mathrm{C}$ because citizens and businesses are the public consumers of the e-government services and G2G is similar to B2B because the interaction between government and government operates much like the interaction between business and business.

The e-commerce success frameworks developed by Keeney (1999) and Torkzadeh and Dhillon (2002) provide a foundation for this study of how to build an egovernment success framework. The following examples illustrate the similarities between e-commerce and e-government. In successful e-commerce transactions, customers must feel that they get better value with Internet shopping than with conventional shopping, whereas to achieve successful e-government, citizens must feel that they get better value with online government service than with conventional government service. E-commerce and e-government offer the public the same values, such as reduced cost, reduced time of transaction, increased convenience, and minimized environmental impact. In his study of e-commerce, Keeney (1999) interviewed over one 
hundred individuals regarding the pros and cons of using e-commerce that they experienced or envisioned. These collected values were organized into twenty-five categories of objectives that were influenced by Internet purchases. These categories were separated into sets of variables: means objectives and fundamental objectives used to describe the bottom-line consequences of concern to customers. Based on Keeney's work, Torkzadeh and Dhillon (2002) further explored the e-commerce values, resulting in two instruments that together measure that influence e-commerce success. One instrument assesses the means objectives that measure the factors that influence online purchases, including online payment, Internet product choice, vendor trust, and shopping travel. For e-government, the Internet product and vendor are to be viewed as egovernment services and government, respectively. Thus, the factors such as online payment, vendor trust, and shopping travel are applicable to both e-commerce and egovernment. The other instrument assesses the fundamental objectives that measure the factors that customers perceive to be important for Internet commerce, encompassing Internet shopping convenience, ecology, customer relations, and product value. For egovernment, Internet shopping and products can be viewed as e-government transaction and services. Thus, the factors such as Internet shopping convenience, ecology, and customer relations are applicable to both e-commerce and e-government.

Bringing the best practice from Internet commerce to e-government commerce leads to its success. Schubert and Hausler (2001) viewed e-government as the governmental counterpart to e-business - the use of information technology (IT) infrastructure for procurement, distribution of services, and internal organization. Thus, researching the e-commerce model is imperative when studying electronic services in the 
public sector. Two e-commerce research studies by Keeney (1999), and Torkzadeh and Dhillon (2002) provide a useful list and a meaningful building block for constructs that can be referenced in this study.

\section{Differences Between E-government and E-commerce}

While the similarities between e-government and e-commerce are largely in the technical and functional arena, the differences are mainly in the inherited nature of public administration and governance. E-government links people not just to each other and the e-commerce marketplace, but also to the public marketplace of ideas, debate, priorities, initiatives, innovation, services, transactions, and results (Council for Excellence in Government, 2001).

The case study by Jorgen and Cable (2002) reflected that there are three salient distinctions between e-government and e-commerce: access, structure, and accountability. To provide access, business has the luxury of domain - choice flexibility, meaning the ability to choose its customers - whereas government cannot because digital government services must, in most societies, be made accessible to all (Elmagarmid \& McIver, 2001). A lack of access to e-government technology can further economic inequities and limit choices and opportunities for the poor, the elderly, and historically underrepresented groups, creating a "digital divide" in the public sector (Jorgen \& Cable, 2002). Another significant access issue relates to persons with disabilities where American Disability Act (ADA) accessibility has been a priority for e-government. The structure of government creates a number of concerns not relevant to the business sector. Decision-making authority is much more dispersed in the public sector than the private and the lines of 
authority are often not as direct. Dispersed authority could become a challenge for the implementation of e-government, since each authority has independent capacity to set priorities and formulate budgets. In addition, concerns arise in relation to standardizing format and procedures, encouraging innovation, and managing processes and progress (Jorgen \& Cable, 2002). The difference between e-commerce and e-government in accountability can be traced back to the nature of democratic government addressed in fiscal performance and political responsiveness. The case study by Jorgen and Cable (2002) in Corpus Christi found that, compared to e-business, e-government usually takes longer to implement, costs more, and delivers less. This less efficient fiscal performance results from two factors: citizen's expectations that the latest technology will be made available for public services, which can conflict with the government's continued attempt to develop new applications, such as e-government, which require significant commitments of both time and money and is often a trial-and-error process. Political responsiveness under the watchful eye of political bodies could result in micromanagement in order to assure accountability. Thus, there is the likelihood that the timely implementation of emerging technology can prove challenging and the egovernment performance can be compromised.

Another significant difference between e-government and e-commerce is the aspect of user participation via interactive dialogs. Though e-commerce users interact with vendors and other pertinent parties, the magnitude of citizen participation in egovernment is much greater in scale in the context of promoting e-democracy. As egovernment must rest on and support democratic principles (Gronlund, 2003), edemocracy aims at active participation and influence in democratic processes via the 
Internet, such as e-town halls and e-forums, through which citizens, political organizations, and lawmakers interact with each other.

Despite similar reliance on Internet technologies and a shared need to progress along the information-communication-transaction-transformation continuum, egovernment faces some issues and challenges uniquely different from those of ecommerce (Chen, 2002). To some, e-government might seem to be little more than an effort to expand the market of e-commerce from business to government. Surely there is some truth in this. E-commerce is marketing and sales via the Internet. Since governmental institutions take part in marketing and sales activities, both as buyers and sellers, it is not inconsistent to speak of e-government applications of e-commerce. Governments do after all conduct business. But e-commerce is not at the heart of egovernment. The core task of government is governance, the job of regulating society, not marketing and sales. In modern democracies, responsibility and power for regulation is divided up and shared among the legislative, executive, and judicial branches of government. E-government is about moving the work of all of these branches, not just public administration in the narrow sense (Gorden, 2002).

\section{E-government Measurement Criteria}

The importance of measuring the performance of e-government cannot be overemphasized (Gupta \& Jana, 2003). A great number of e-government measurement criteria have been introduced; while some methods are similar in nature, only the distinct and significant methods are illustrated here. Identifying the existing e-government measurement criteria clarifies the current state knowledge and provides research 
opportunities for further development of the field; it is also a major objective of this study. Up to the present, no e-government measurement criteria grounded in the DA value theory as approached by this study was found. Thus, this study advances knowledge and contributes to understanding the e-government phenomena that are an integral part of modern IS research.

Research into determining public expectations from e-government and into determining whether current or proposed e-government systems deliver according to public expectations may borrow from and progress along the lines of the SERVQUAL model used in the marketing discipline, which is a good predictor of overall service quality (Fisk, Brown, \& Bitner, 1993). This model uses gap analysis to identify and measure five different types of gaps that may exist between customers' expectations and perceptions of service. The five gaps are (1) the service gap between public expectations from the e-government services and the perception of service delivered, (2) the understanding gap between public expectations and management perceptions of what these public expectations are, (3) the design gap between management's understanding of public expectations and the design and specification of service quality, (4) the delivery gap between the specification of service quality and the actual quality of the service delivered, and (5) the communication gap between what is actually delivered and what is promised (Jain \& Patnayakuni, 2003).

To assess the breadth and width of the implementation of e-government initiatives, progress will be measured using a four-stage format (Layne \& Lee, 2001) that reflects the growth model of e-government:

Stage 1, Cataloging (online presence, catalogue presentation, downloadable forms): In this stage, basic and non-transactional information are provided through a one- 
way interface. Usually, at first, the index site is organized on the basis of functions or departments as opposed to service access points.

Stage 2, Transaction (services and forms are online, working databases support online transactions): This stage empowers citizens to deal with their governments online anytime to save hours of paperwork, the inconvenience of traveling to a government office, and time spent waiting in line. Filing taxes and registering businesses online are only the beginning of such transaction-based services.

Stage 3, Vertical Integration (local systems are linked to higher level systems within similar functionality): Citizens are able to access the service at the higher level of governments (State and Federal) from the same entry as the municipal portal because the local systems are connected to upper level systems directly or indirectly.

Stage 4, Horizontal Integration (systems are integrated across different functions, real one-stop shopping for citizens): The horizontal integration of government services across different functions of government will be driven by visions of efficiency and effectiveness in using IT, but will be pulled by citizens' demands for an "inside-out" transformation of government functions toward more serviceoriented ones. Such integration will facilitate "one-stop shopping" for the citizen. Each organization may have to give up some power to move to this stage.

Steyaert (2004) proposed a marketing model to be used to improve the content and value of e-government services. Five marketing indicators were used - consumer awareness, popularity, contact efficiency, conversion, and retention. Awareness deals with the number of visitors to a site. Popularity refers to the ranking of the site. Contact efficiency indicates site usability and content. Conversion refers to customer satisfaction, transaction, and time spent on the site. Retention deals with customer loyalty. Web traffic reports and customer surveys were used as proxies to analyze and compare a sample of e-service agencies.

Gupta and Jana (2003) suggested a flexible framework from which to choose an appropriate strategy to measure the tangible and intangible benefits of e-government. The broad categorization includes hard measures (cost-benefit analysis and benchmarks in e-government), soft measures (scoring method, stages of e-government and social 
angle), and hierarchy of measures (means to measure the variables, such as return on investment, for which criteria are established).

Doctor and Ankem (1996) identified two dimensions of the taxonomy for categorizing community information systems. One dimension consists of 14 types of services: commerce, consumer affairs, education and schooling, employment, financial matters, governmental processes with politics and policy, health and medical, home and family, housing, legal matters, nature and environment, recreation and culture, social services, and transportation. The other dimension consists of five categories of services: advocacy, counseling, and factual, directional, and interactive communication.

Stowers (2002) examined 148 federal government Web sites based on online services, user help features, navigation features, and information architecture. The reviewers used four indices of these categories plus a scale of accessibility to yield the total excellence score.

The United Nations (2002) conducted a study to assess the progress of e-government transformation and quality of the e-government Web sites at the global level by benchmarking various countries. The variables used in this study were based on the following questions:

1. Does the site link to any other sites, such as different levels of government, and public and private organizations?

2. Is there a city e-government strategic plan online?

3. How is the site's content organized?

4. Is the site multi-lingual?

5. Does the site offer a search feature that is easy to use and accurate?

6. Is there a site security feature?

7. What form or method of online payment (for any transaction) is used?

8. Is there a direct link to specific individual services or all available online forms?

9. Can the documents be saved or downloaded?

10. What kind of special features, such as accepting digital signatures and offering 
streaming media (like live video or audio of events) are available?

11. Does the site offer push technology?

12. How current is the content?

Gartner's framework (2002) is based on the three e-government strategies: service levels to constituents (for example: Is the service what they need? Are they using it? Does it provide greater value at a lower cost than the offline service?), operational efficiency (for example: Are online transactions reducing government costs?), and political return (for example: Is the e-government initiative increasing consensus? Are there any positive effects on the economy and the society at large?). Although this framework is not designed to rank initiatives from the most to the least valuable, it will enable governments to reprioritize established initiatives and identify new initiatives that are required.

Jorgensen and Cable (2002) conducted a case study based on control and coordination among city departments, service levels, fiscal and political support, and appropriate and efficient technology. Due to the lack of previous research in the area, the case study approach allowed the development of an in-depth empirical inquiry of the subject in a quasi-experimental design.

The 2000 e-government survey conducted by the International City/County Management Association and Public Technology Inc. reflected that e-government includes four major internal and external aspects: (1) the establishment of a secure government Internet and central database for more efficient and cooperative interaction among governmental agencies, (2) Web-based service delivery, (3) the application of ecommerce for more efficient government transaction activities, such as procurement and contract, and (4) digital democracy for more transparent government accountability and 
increased citizen participation in rule making, where regulations that affect all aspects of life from food to transportation and the environment are open to comment and debate.

The lifeblood of government is information, and the digital revolution has allowed government organizations to more effectively and efficiently store, analyze, and retrieve information (Bretschneider, 2003). At present, access to information is one of the most popular features of e-government services; thus, increasingly, governments are creating a presence on the Internet through the use of a Web page or site where a variety of information is offered to the public. While searches may retrieve a great number of items, the best-matched items from the search query are placed at the top of the result list. Result ranking in information retrieval has a major impact on users' satisfaction with Web search engines and their success in retrieving relevant documents. Result ranking is judged by three criteria (Courtois \& Berry, 1999):

1. All terms: Does the document contain at least one occurrence of all search terms?

2. Proximity: Is there at least one occurrence of all search terms appearing as a contiguous phrase?

3. Location: Is there at least one occurrence of all search terms appearing within the title, headers, or metatags?

\section{Value Theory (Value-Focused Thinking Approach)}

Values in the discipline of operation research are expressed as objectives, goals, criteria, performance measures, weights, preferences, and/or objective functions (Keeney, 1992). The proposed study will focus on values expressed as objectives in the field of DA. In the DA theory, the decision maker is to make decisions consistent with a certain set of 
values (Spradlin, 20005). Values might be economic, personal, social, or others. A common value is economic, from which the decision maker will attempt to increase wealth. Personal value could be convenience or security while social value could mean protection of environment. This research focuses on the values that lead citizens (the decision maker) to use e-government services instead of conventional government services (the decision context). Values should remain relatively stable unless they are related to the emergence or alleviation of major issues (Rokeach, 1974).

In recent years, one of the most interesting areas of research has been the measurement of value systems (Kamakura \& Mazzon, 1991). The framework of the value system for this study is based on the Value-thinking approach by Keeney (1992) in the field of DA. Keeney (1992) proposed the concept of a value proposition: value-focused thinking that provides a framework for defining value to the customers. He posited that many books written about decision-making address how to solve decision problems by evaluating alternatives given some quantitative objective function, yet do not discuss how to articulate the qualitative objectives on which any appraisal of alternatives must rest. Values are fundamentally important in any decision situation. Alternatives are relevant only because they are a means to achieve the desired values. Thus, the thinking should focus first on values and later on alternatives that might achieve them. This value-focused thinking can significantly improve decision-making because the values guide not only the creation of better alternatives, but also the identification of better decision situations (Keeney, 1992).

To understand value-focused thinking, three classes of definitions need to be considered. These are the decision context, values, and fundamental objectives. The 
decision context presents alternatives appropriate for a given decision situation and is specified by the range of activities being contemplated (Torkzadeh \& Dhillion, 2002). For example, the decision context is whether or not to make purchases over the Internet (Keeney, 1999). Values are principles used for evaluating the desirability of possible alternatives in a specific decision situation (Keeney, 1992). Values come into play prior to a given decision problem. If the question of whether to purchase on the Internet or through conventional shopping is to be construed as a decision problem, then values afforded by the customer will form the basis for evaluating the alternatives (Torkzadeh \& Dhillion, 2002). Fundamental objectives make explicit the values that one cares about and define the consequences of concern (Keeney, 1992). This study is based on the value-thinking approach that extracts the e-government values from surveys of citizens who have experience in using e-government services.

\section{Means Objectives and Fundamental Objectives}

Using the value-focused approach, Keeney (1999) conducted an empirical study to explore the value of Internet commerce and proposed two sets of variables: means objectives, and fundamental objectives for Internet shopping. He posited that means objectives are those that help businesses achieve what is important to their customers fundamental objectives. Fundamental objectives make explicit the values and define the consequences of concern (Keeney, 1992). This impacts the ends that a decision maker may value in a decision context. Therefore, fundamental objectives are the end objectives, as opposed to the means objectives. Means objectives are the ways to achieve the ends. Keeney uses the "Why is that important?" test to classify the means and 
fundamental objectives where there are two possible types of answers. One type of answers reflects the given objective that is one of the essential reasons for interest in a situation, whereas the other type reflects the given objective that is important because of its implication for another objective. Objectives with the former response are fundamental objectives; and those with the latter are means objectives. For example, means objectives such as minimizing misuse of credit card or minimizing misuse of personal information are important because they influence fundamental objectives such as minimizing personal hassle and minimizing cost (Keeney, 1999). If the answer reflects different decision contexts, it constitutes a fundamental objective. For example, saving time is important because saved time can be used for other interests. Other interests reflect different decision contexts. Therefore, in the context of using egovernment services, saving time (the "minimizing time spent "objective) constitutes a fundamental objective.

The following examples further describe these two variables applied in different fields expressed in similar terms. Nah, Siau, and Sheng (2005) in their value research of mobile applications stated that fundamental objectives, as the name implies, underlie the essential reasons for the given situation, whereas means objectives are those whose attainment will help achieve fundamental objectives. For example, the "minimize errors and mistakes" objective helps achieve the "maximize effectiveness" objective. Thus the first objective is a means objective, and the other is a fundamental objective. Dhillon and Lee (2000) in their IS value assessment study categorized the two variables by determining if an objective is an intermediate one (being a means objective) or a final one (being a fundamental objective). For example, the "increase system consistency" 
objective (the intermediate) affects the "increase ease of use" objective (the final). Therefore, the former is a means objective, and the latter is a fundamental objective. These two interrelated categories of objectives are components of the same overall construct, measuring factors that influence the success of e-government initiatives.

\section{Derivation of E-government Value From Technology}

One of the most recent significant innovations in IS has been the creation and ongoing development of the Internet. The Internet increases communication flexibility while reducing communication cost, by permitting the instantaneous exchange of large amounts of information regardless of geographic distance and time. It is profoundly changing the way the society communicates, works, and learns (Council for Excellence in Government, 2001). Similar to the dramatic changes in e-commerce, the e-government revolution offers the potential to reshape the public sector and remake the relationship between citizen and government (West, 2000).

In the context of e-government products and services for citizens, values are largely derived from enhanced information dissemination, increased transactions online, and accelerated use of emerging technology. Balutis (2001B) illustrates these values with examples. Information dissemination can be enhanced by expanding the amount of information accessible on searchable databases drawing from an enormous amount of information available to the government. In addition, the information can be provided "by request." For example, companies should be able to answer a questionnaire and automatically receive e-mail informing them of each government procurement solicitation that matches criteria they entered. Moreover, an "expert system" could be 
used to provide expert advice to the businesses. For example, the Occupational Safety and Health Administration has developed a series of online expert "adviser" systems to help business people identify safety problems in the workplace, from mercury to asbestos, and determine an appropriate course of action. Online transactions can be increased in the area of monetary transfer, benefits, and purchasing and services (e.g., paying taxes and applying for permits). Transferring funds online would not only save government and businesses both time and money when performing transactions, but also help both parties reduce record-keeping efforts because it automatically creates an accurate record of transactions. Automatic allocation of benefits, such as using electronic benefits transfer, would reduce paperwork and costs. To the extent that governments sell items, businesses should be able to purchase them online. In addition, the government could utilize an online auction for disposing of surpluses of government property (Balutis, 2001B). Expanded access to government portals via various emerging technologies would provide a great value to customers when they interface with government sites, such as using cell phones and palm computers. Experience in Europe and Asia suggests that "access anywhere" is increasingly important for citizens, businesses, and employees (Balutis, 2001B).

E-government value could be derived from the inherent nature of Internet technology, which facilitates access by reaching far beyond the traditional constraints of region and time. Thus, a U.S. taxpayer living in Africa could file a federal income tax return online with the Internal Revenue Service, a tour company in Asia could access upto-date sightseeing information in Los Angeles via the Los Angeles city Web site, and an exporting company in Europe could inquire about marketing opportunities for its 
products using the New York State Web sites. And reaching beyond traditional business hours frees citizens to seek information at their own convenience 24 hours a day, seven days a week, not just when a government office is open (West, 2004).

To achieve success with e-government initiatives, e-government services need to provide values to their users. E-government and e-commerce are similar in that they are based on Internet technology designed to facilitate the exchange of goods, services, and information between two or more parties (Carter \& Belanger, 2004). Hence, the following questions that Keeney (1999) stated based on the values of individual ecommerce customers are relevant to e-government as well: What does the service offer the customer? How can it offer more to the customer than is currently available through conventional means? Keeney said that since Internet commerce is not a product, but a means to purchase products, there is no value proposition of Internet commerce. Hence, the value proposition applicable to Internet commerce is a net value of the benefits and costs of both a product and the processes of finding, ordering, and receiving that product. E-government products and services offered through Internet have great potential to provide value to users. E-government value is an important construct for academics and professionals studying e-government, since it helps to develop success measures (Chang, Torkzadeh, \& Dhillon, 2004). 


\section{Chapter 3}

\section{Methodology}

\section{Introduction}

Most research on the use of the Internet tends to be conceptual rather than empirical in nature (Teo \& Pian, 2004). This research proposed an empirical study, focusing on collecting the values citizens assign to e-government services. This study first generated a list of e-government objectives from the exploratory study of Internet commerce by Torkzadeh and Dhillon (2002) and the published research pool. Then the list was grouped into two types: means objectives, and ends objectives. Using this model, a survey with a total of 76 questions (48 questions for the means and 28 questions for the fundamental objective types) was conducted focusing on these two different types of objectives.

Upon collection of the data, data reduction and analysis were performed using factor analysis on each type of items separately. In addition, this study related the means and ends factors by examining the cross-correlations among factors. The outcome of this study was two instruments that together measure the factors that influence the success of e-government initiatives. One instrument measures the means objectives that influence using e-government services, and the other measures the fundamental objectives that are essential reasons for using e-government services. The instrument development process is shown in Figure 1. 


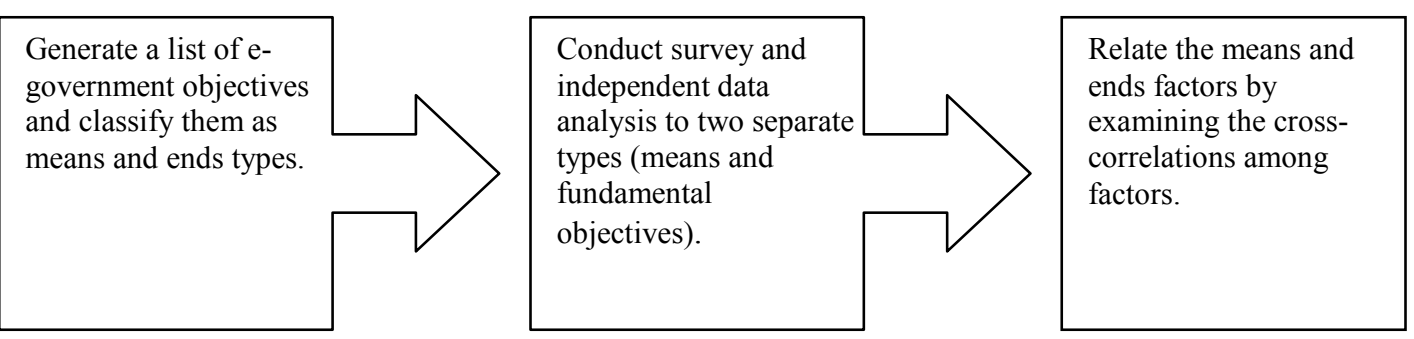

Figure 1. Steps for instrument development.

\section{Scope Definition}

The initial task in identifying the instrument was to define the scope of the research by answering the seven questions in table 5 , which are adapted from the seven questions to ask when measuring organizational performance (Cameron \& Whetten, 1983).

Table 5

Measuring Organizational Performance

Question

From whose perspective is effectiveness being judged?

What is the domain of activity?

What is the level of analysis?

What is the purpose of evaluation?

What is the time frame employed?

What types of data are to be used?
Answer

Users of e-government

E-government services

User

Developing factors that

influence success of e-

government initiatives

Snapshot

Survey data from e-gov users 
Question

Against which referent is effectiveness to be judged?
Answer

In-line vs. online

\section{Procedures}

\section{Generating a List of E-government Objectives and Classifying Them as Means and Ends Types}

In order to provide the basis for formulating a model of e-government value, this study identified e-government objectives. These objectives then were classified into two types: means and ends objectives. E-government values reflected the benefits and costs of what the network-based IS, such as the Internet, offers to citizens in terms of information, products, and services, and how these offerings (the alternatives) can be better than what is currently offered through conventional means. The first list of egovernment objectives was extracted from the 125 items in Appendix A developed from the exploratory study of Internet commerce by Torkzadeh and Dhillon (2002). The second list was extracted from the research pool mostly published in the leading refereed publications during the 6-year period from 2000 to 2005 (see Appendix E). The two lists of objectives were combined and classified into means and ends types depending on the characteristics of attributes. Later in the study, data analysis was conducted against these two types independently. The process to extract and classify e-government objectives is illustrated in the next two sections (depicted in Figure 2). 
Extracting e-government objectives from the Internet commerce study.

Source: The study by Torkzadeh and Dhillon (2002) in Appendix A

Examples:

- I am concerned about hackers.

- I am concerned about charging errors.

- I feel human customer support is important.

- It is important to minimize search time.
Extracting e-government objectives from the e-gov research pool.

Source: Research publications during the 6-year period from 2000 to 2005 in Appendix B

Examples:

- Participatory government

- Access to information

- Improved service

- Privacy protection

- Integration of governments

Generating and classifying the e-government values into means and ends objectives.

Means Objectives: Helping to achieve one or more of the other objectives (listed in Table 6)

Maximize Interactivity

Maximize Access to E-government

Promote E-democracy

Maximize Access to Information and Service

Maximize Information Availability

Maximize Service Information

Maximize Presentation

Assure Security

Minimize Misuse of Personal Information

Assure Reliable Delivery

Maximize Service Quality

Maximize Use of Emerging Technology

Maximize Ease of Use
Ends Objectives: Fundamental reasons for using e-government (listed in Table 7)

$\rightarrow \quad$ Maximize citizen satisfaction

Maximize Convenience

Minimize Cost

Minimize Time Spent

Minimize Time to Receive Information and Service

Maximize Enjoyment

Maximize Safety

Minimize Environment Impact

Figure 2. E-government value extracting process. 


\section{Extracting E-government Objectives From the Internet Commerce Study}

A study by Torkzadeh and Dhillon (2002) conducted a survey of working college students with experience in shopping on the Internet. The study was based on Keeney's 1999 proposed framework that identified 91 objectives that might influence a consumer to purchase online. Torkzadeh and Dhillon's empirical study (2002) generated 125 items that measure the factors that influence Internet commerce success. Their study resulted in suggesting a 5-factor, 21-item instrument for measuring means objectives that influence Internet purchasing (e.g., online security) and a 4-factor, 16-item instrument for measuring fundamental objectives that are important for Internet purchasing (e.g., online convenience). Though the 125 items, including 72 means and 53 fundamental objectives, developed by Torkzadeh and Dhillon (2002), are based on e-commerce research, the majority reflects common factors in e-government. For this study, items not applied to e-government services were eliminated from the list in Appendix A. For example, while "minimizing pollution" is a common factor, "choice of products" is not, because choices are seldom an option in e-government services. Hence, it was removed. As the items developed by the Torkzadeh and Dhillon study were already classified as means and fundamental objectives, the classification of the selected items remained the same.

\section{Extracting E-government Objectives From the E-government Research Pool}

An instrument valid in content is one that has drawn representative questions from a universal pool (Straub, 1989). Additional e-government objectives were extracted from the broad research pool published mostly in the leading refereed literatures. The list of 
publications found Appendix E covers the 6-year period from 2000 to 2005. The extracting process involved:

1. Extracting e-government objectives (values) from the literatures

2. Converting and grouping them into general objectives

3. Classifying the general objectives to means objectives and ends objectives (fundamental objectives).

Extracting e-government values required exploring the publications listed in Appendix B and identifying the e-government objective items from them. For example, the first publication on the list, Government Information Quarterly, was concerned about two e-government objective items: the digital divide and usefulness of information. Digital divide refers to concerns about inequities between citizens who do not have access the Internet, and those who do. Usefulness of information concerns validity, accuracy, clarity, frequency, sufficiency, timeliness, reliability, relevancy, message content, and cost. The likelihood of owning a PC with Internet access to embrace electronic services varies significantly by household income, education level, age, and region. A thoughtful response by governments to shrink these disparities to promote an information-rich society will be a major factor in the success of e-government initiatives in the coming years.

Converting and grouping the e-government objective items into general objectives required a structured process. As the e-government objective items from the research pool came in various forms, to develop some consistency in these expressions, each item was converted into a corresponding objective. To convert, the items were expressed in the three objective features: decision context, object, and direction of preference (Keeney, 
1999). The decision context was whether to use e-government services. The object was a noun and the direction of preference is a verb. Thus, for example, "participatory government" became "participate in decision-making" and "privacy problem" became "assure privacy". Once the items were converted, similar objectives were grouped into categories. For example, objectives such as "participate in decision-making", "promote e-voting", and "minimize digital divide" were categorized as a part of a general objective of "promote e-democracy".

Classifying the general objectives to means objectives and fundamental objectives required relating categories by means-ends relationships. For each general objective, the importance of the decision context was grouped into two categories: one helps to achieve one or more of the other objectives; the other is one of the fundamental reasons for using e-government services. Objectives in the first category were referred to as means objectives, and those in the second were referred to as fundamental objectives (Keeney, 1999). Keeney used the "Why is that important?" test to classify the means and fundamental objectives where there were two possible types of answers. One type of answer was that the given general objective was the essential reason for using egovernment services, whereas the other type was that the given general objective was important because of its implication for another objective. Objectives with the former response are fundamental objectives, and those with the latter are means objectives. Means objectives help to achieve the ends that are fundamental objectives. For example, e-voting (the means) helps achieve time flexibility (the ends) as voting can be done in a wide range of time because the voter needs not to physically appear at the voting booth, providing convenience (the fundamental objective). For another example, minimizing 
digital divide (the means) not only provides the convenience (the fundamental objective) of using online e-government services for those who otherwise would not have access to Internet, but also increases the usefulness of information (the fundamental objective) because more people can view and, thus, make use of the information. Additional examples of these two objectives are illustrated in the Means Objectives and Fundamental Objectives section in page 39. The compiled e-government objective items with the associated classified objectives from the research pool are listed in Table 6 . While the common objectives between e-government and e-commerce are largely in the technical and functional arena from transformation of the business of governance, i.e. improving service quality delivery, and reducing costs, the e-government specific objectives are mainly derived from transformation of governance, i.e. re-examining the functioning of democratic practices and processes (Aichholzer \& Schmitzer, 2000) that link people to the public place of ideas, debate, priorities, initiatives, innovation, services, transactions, and results (Council for Excellence in Government, 2001).

Table 6

E-government Objective Items From the Research Pool With the Categorized Egovernment General Objectives: Means Objectives (MO) and Ends Objectives (EO)
Objective Items
General Objectives

- Concerns about inequities among citizens (Gupta \& Jana, 2003)

Maximize access to e-government (MO)

- Usefulness of information Maximize convenience (EO) (Gupta \& Jana, 2003)

- Participation in decision making Promote e-democracy (MO) (Elmagarmid \& McIver, 2001)

- E-filing of petitions Maximize access to information 
Table 6 (continued)

Factors General Objectives

(Elmagarmid \& McIver, 2001)

- Disability access

(Elmagarmid \& McIver, 2001)

- Foreign language

(Elmagarmid \& McIver, 2001)

- Simplify data access

(Elmagarmid \& McIver, 2001)

- Bring citizens closer to their governments (Pons, 2004)

- Information security and privacy (Pons, 2004)

- Linking supply chain (Scherlis \& Eisenberg, 2003)

- Using emerging technology (Scherlis \& Eisenberg, 2003)

- Knowledge sharing (Wagner, 2003)

- Information exchange (Wagner, 2003)

- Greater government accountability (Jain \& Patnayakuni, 2003)

- Collaboration between federal, state, and local governments (Pandy, 2002)

- Increased geospatial information (Pandy, 2002) and services (MO)

Maximize access to e-government (MO)

Maximize presentation (MO)

Maximize ease of use (MO)

Promote e-democracy (MO)

Assure security (MO)

Maximize convenience (EO)

Maximize use of emerging technology (MO)

Promote e-democracy (MO)

Promote e-democracy (MO)

Promote e-democracy (MO)

Maximize access to information and services (MO)

Promote e-democracy (MO) 
Table 6 (continued)

Factors

General Objectives

- Promoting public participation in policy-making process (Moon, 2002)

- Improved communication (Moon \& Welch, 2004)

- Information retrieval (Jorgensen \& Cable, 2002)

- Effective communication with citizens (Jorgensen \& Cable, 2002)

- Timeliness of response (Jorgensen \& Cable, 2002)

- Two way interaction (Muir \& Oppenheim, 2002)

- Billboard features (West, 2004)

- Improved service delivery (West, 2004)

- Public outreach and democracy enhancement (West, 2004)

- Facilitated access to public information and services (Strejcek \& Theil, 2002)

- Increased transaction function (Aichoholzer \& Sperlich, 2001)

- Ease of interaction (Anttiroiko, 2004)

- Sufficient supply of information and services (Dearstyne, 2001)

Promote e-democracy (MO)

Maximize interactivity (MO)

Maximize convenience (EO)

Promote e-democracy (MO)

Minimize time spent (EO)

Maximize interactivity (MO)

Maximize access to information and services (MO)

Maximize service quality (MO)

Promote e-democracy (MO)

Maximize access to information and services (MO)

Maximize convenience (EO)

Maximize convenience (EO)

Maximize access to information and services (MO) 
Table 6 (continued)

Factors

General Objectives

- $\quad$ Ease of contact (Thomas \& Streib, 2003)

- Availability of forms (Balutis, 2001A)

- Providing seamless service (balutis, 2001A)

- Ease of interaction (Swartz, 2004)

- Ease of use for information and services (Wert, 2002)

- Horizontal and vertical integration of governments (Wert, 2002)

- $\quad$ Electronic governance (Roy, 2003)

- Electronic service delivery (Roy, 2003)

- Services provided by function as opposed to by department (Clark, 2003)

- One-stop portal (McGinnis, 2003)

- Citizen-centered facility (McGinnis, 2003)

- Useful service (Carter \& Belanger, 2004)

- Compatibility of life style (Carter \& Belanger, 2004)

- Democratic responsiveness (West, 2004)

- Public outreach (west, 2004)

- Information format desired by users (Dawes, Pardo, \& Cresswell, 2003)

- Convenient and costless e-government services (Steyaert, 2004)
Maximize convenience (EO)

Maximize convenience (EO)

Maximize convenience (EO)

Maximize convenience (EO)

Maximize convenience (EO)

Maximize access to information and services (MO)

Promote e-democracy (MO)

Maximize convenience (EO)

Maximize ease of use (MO)

Maximize convenience(MO)

Maximize citizen satisfaction (EO)

Maximize convenience (EO)

Maximum use of emerging technology (MO)

Promote e-democracy (MO)

Promote e-democracy (MO)

Maximize presentation (MO)

Maximize convenience (MO) 
Table 6 (continued)

Factors

General Objectives

- Integrated access structure (Lenk \& Traunmuller, 2000)

- Seamless government (Lenk \& Traunmuller, 2000)

- Free Internet access to e-government (Prattipati, 2003)

- Enhanced information dissemination (Balutis, 2001B)

- Security and privacy (Mittal, Kumar, Mohania, Nair, Batra, Rey, Saronwala, \& Yagnik, 2004)

- One-stop service (Lenk, 2002)

- Convenient and inexpensive services (Council for Excellence in Government, 2001)

- $24 \times 7$ availability of services (Vriens \& Achterbergh, 2004)

- Fast service (MedJahed, Rezgui, Bouguettaya, \& Ouzzani, Jan./Feb., 2003)

- Fast delivery of information (Fugini \& Mezzanzanica, 2004)
Maximize access to information and services (MO)

Maximize access to information and services (MO)

Maximize access to e-government (MO)

Maximize assess to information and services (MO)

Assure security (MO)

Maximize convenience (EO)

Maximize convenience (EO)

Maximize convenience (EO)

Minimize time spent (EO)

Minimize time to receive information and service (EO) 


\section{Combining E-government Objectives From the Internet Commerce Study and the \\ E-government Research Pool}

To generate an overall list of e-government objectives used for this study, the objectives from the e-government research pool were integrated with those from the Internet commerce study by Torkzadeh and Dhillon (2002). As the objectives had been classified into two types during the extracting process, the list consisted of two different types accordingly: means objectives and ends (fundamental) objectives. They are listed in Table 7 and Table 8 respectively. These two types of objectives became the basis for developing two instruments that, taken together, measure the factors that influence the success of e-government initiatives, which was the goal of this study.

Table 7

Means Objectives for E-government Services

Maximize Interactivity

Maximize two-way interaction

Provide opportunity for personal interaction

Improve communication

Maximize Access to E-government

Maximize universal access

Maximize accessibility by individuals with disabilities

Promote E-democracy

Maximize participation in decision making

Maximize knowledge sharing

Promote e-services (i.e., e-vote, e-forum, etc.)

Maximize transparency

Promote public outreach

Maximize Access to Information and Services

Maximize horizontal and vertical integration of governments

Facilitate information dissemination

Maximize "information on request" 
Table 7 (continued)

Maximize search criteria

Maximize Information Availability

Maximize amount of information

Maximize up-to-date information

Facilitate adding new information

Maximize choice of information

Minimize missing information

Maximize Service Information

Maximize information about service

Maximize available service information

Maximize Presentation

Maximize use of style and format

Maximize appealing

Maximize ease of viewing

Maximize use of foreign languages

Assure Security

Discourage unauthorized access

Discourage hacking

Maximize transaction security

Minimize misuse of credit card

Minimize misuse of personal information

Minimize Misuse of Personal Information

Maximize safeguard of personal information

Minimize sharing of personal information

Minimize receipt of unsolicited material

Assure Reliable Delivery

Provide reliable delivery

Assure arrival of requested information and service

Maximize Service Quality

Ensure quality of service

Maximize transaction accuracy

Minimize charging errors

Maximize Use of Emerging Technology

Promote new type of services 
Table 7 (continued)

Promote compatibility of life style

Maximize Ease of Use

Maximize ease of access

Maximize search process easy

Maximize ease of use for information and service

Simplify finding desired information and services

Table 8

Fundamental Objectives for E-government Services

Overall Objectives

Maximize citizen satisfaction

Maximize Convenience

Maximize time flexibility in using service

Minimize personal contact

Minimize effort of receiving service

Minimize personal hassle

Maximize ease of finding information and service

Maximize usefulness of information and service

Minimize Cost

Minimize service cost

Minimize travel cost

Minimize communication cost

Minimize Time Spent

Minimize time to find information and service

Minimize processing time

Minimize search time

Minimize payment time

Minimize communication time

Minimize time to select information and service

Minimize time to request information and service

Minimize Time to Receive Information and Service

Minimize delivery time

Minimize shipping time 
Table 8 (continued)

Minimize dispatch time

Maximize Enjoyment

Make visiting e-government a social event

Inspire citizens

Minimize regret

Maximize Safety

Prevent public hazard

Maximize driving safety

Minimize Environment Impact

Minimize environmental damages

Minimize pollution

\section{Conducting Survey and Data Analysis}

\section{Design of Case Study}

The next step was to perform a quantitative empirical study to explore the list of e-government objectives as success factors by conducting a survey and developing instruments that measures factors that influence the success of e-government initiatives. The instruments will be tested for validity and reliability. The case study was conducted with the following framework:

1. Type of investigation - Correlational

2. Extent of researcher interference - Minimal

3. Measurement - Scaling

4. Instrument validation - Validity and reliability

5. Data-collection - Probability sampling and Web survey 
6. Time horizon - One-shot (cross sectional)

7. Unit of analysis - Individual

\section{Type of Investigation}

Since the objective of this study was to identify the factors associated with the problem rather than to establish a definitive cause and effect relationship, a correlational study was called for. The researcher delineated the success factors that were associated with the e-government initiatives.

\section{Extent of Researcher Interference}

A correlational study was conducted in the noncontrived setting where the relevant data were collected and analyzed to present the findings with minimum interference (Sekaran, 2000). The Web survey for this study allowed the respondents to provide answers in a natural environment.

\section{Measurement}

From two main categories of attitudinal scales, rating scale and ranking scale, the rating scale was appropriate for this study because this interval is more powerful than the nominal and ordinal scales in performing the arithmetical operations on the data collected from the respondents. Its measures of dispersion are the range, the standard deviation, and the variance (Sekaran, 2000). Among various rating scales, the Likert-type scale is designed to examine how strongly subjects agree or disagree with brief statements (instead of long questions) on a 5-level scale that is in line with this study method. Hence, 
the instrument used a Likert-type scale with a range from "strongly disagree" to "strongly agree", using words in the scale instead of numeric value (e.g. 1, 2, 3, 4, and 5). Once the selections were made by the respondents, they were assigned corresponding numeric score, 1 for "strongly disagree" to 5 for "strongly agree". The responses over a range of each statement were then summated for every respondent. As the interval scale was used, the differences in the responses between any two ranges on the scale remained the same.

Though Likert scaling is a commonly used instrument for measuring beliefs (DeVellis, 2003), it is subject to a response set that reflects the tendency of a respondent to reply to questions in a certain way independently of the content of the questions. This tendency is derived from the nature of the Likert-type instrument, in which the question is presented as a declarative sentence, followed by response options that exhibit varying degrees of agreement with the statement (DeVellis, 2003). One such response bias is the tendency to agree rather than disagree, or the tendency to make extreme responses (Rennie, 1982). Another is the tendency to not focus much attention on subtleties of language by merely regarding any reasonable response option in the center of the range as midpoint, regardless of the precise wording (DeVellis, 2003). For example, very mild statements may cause the tendency for too much agreement because they represent the absence of belief, while extreme statements may cause extreme views. The latter may be less of a problem because this study is interested in the presence of some belief, rather than in its absence. To reduce the response bias, the instruments attempted to state the beliefs in clear terms. Since the purpose of using Likert scale is not to span the range of weak to strong assertions of the construct (DeVellis, 2003), the questionnaires were designed to provide respondents the opportunity for gradations. 


\section{Instrument Validation}

To enhance the quality of the research, the "goodness" of the measures developed were assessed by conducting reliability and validity tests to be reasonably sure that the instruments used in this research measured the variables they are supposed to, and that they measured them accurately (Sekaran, 2000). The instrument validation was set forth according to the kinds of questions answered (Straub, 1989) and the types of references addressed in Figure 3.

\begin{tabular}{|l|l|}
\hline \multicolumn{2}{|c|}{ Instrument Validation } \\
\hline Content Validity & $\begin{array}{l}\text { Are instrument measures drawn from all possible } \\
\text { measures of the properties under investigation? }\end{array}$ \\
\hline Construct Validity & Do measures show stability across methodologies? \\
& artifacts of the kind of instrument chosen? \\
\hline Reliability & $\begin{array}{l}\text { Do measures show stability across the units of } \\
\text { observation? That is, could measurement error be } \\
\text { so high as to discredit the findings? }\end{array}$ \\
\hline
\end{tabular}

Figure 3. Questions and references for the validities.

\section{Content Validity}


Content validity concerns item sampling adequacy-that is, the extent to which a specific set of items reflects a content domain (DeVellis, 2003). Content validity is a function of how well the dimensions and elements of a concept have been delineated (Sekaran, 2000). Content-valid instrument is difficult to create and perhaps even more difficult to verify because the universe of possible content is virtually infinite (Straub, 1989). An instrument valid in content is one that includes an adequate and representative set of items that tap the concept. The more the scale items represent the domain or universe of the concept being measured, the greater the content validity. The instrument proposed in this study was derived from the wide research pool in the leading publications that reflect the view of experts in the field familiar with the content universe. To compile comprehensive e-government value, this research was not only based on a total of 125 items developed by the major Internet commerce study by Torkzadeh and Dhillon (2002) but also explored the e-government research that had been done during the 6-year period from 2000 to 2005 in the literatures from IS and reference discipline. Drawn together, and assigned as the basis for formulating a comprehensive model of egovernment value, these contents should have brought the level of content validity to an acceptable level for the study.

\section{Construct Validity}

Construct validity is directly concerned with the theoretical relationship of a variable (e.g., a score on same scale) to other variables (DeVellis, 2003). It is in essence an operational issue (Straub, 1989) in that it testifies to how well the results obtained 
from the use of the measure fit the theories around which the test is designed (Sekaran, 2000).

Constructs are considered valid when high correlation occurs between measures of the same construct and low correlation occurs between measures of different constructs (Straub, 1989). This study established construct validity through (1) correlational analysis to purify the items and (2) factor analysis to confirm the dimensions of the concept that had been operationally defined, as well as indicated which of the items were most appropriate for each dimension (Sekaran, 2000). To purify the items, the corrected item-total correlation technique was used. If all items in a measure are drawn from the domain of a single construct, responses to those items should be highly intercorrelated (Torkzadeh \& Dhillon, 2002). The correlation of each item with the sum of the other items in its category was evaluated.

\section{Reliability}

Whereas validity concerns whether the variable is the underlying cause of item covariation, reliability concerns how much a variable influences a set of items. Reliability is the proportion of variance attributable to the true score of the latent variable (DeVellis, 2003), reflecting the stability across the units of observation (Straub, 1989). The reliability of a measure indicates the extent to which the measure is without bias (error free) and hence offers consistent measurement across time and across the various items in the instrument (Sekaran, 2000). Internal consistency reliabilities are typically equated with Cronbach's coefficient alpha. Thus, the reliability of items comprising each dimension were examined using Cronbach's $\alpha$ to see if additional items could be 
eliminated without substantially lowering reliability. High correlation between alternative measures or large Cronbach's $\alpha$ is usually signs that the measures are reliable (Straub, 1989).

\section{Use of Factor Analysis}

The focus of science is theory. Data are meaningless in themselves until they are linked through propositions that confer meaning (Rummel, 1970). A scientific theory consists of analytic and empirical components. The analytic component reflects the linkage of reasoning that follows logical rules without empirical content, whereas the empirical component reflects the linking of empirical data for a theory to apply to reality (Rummel, 1970). The empirical component connects the analytic component to the facts. Factor analysis combines analytic and empirical components in order to connect theory to social phenomena (Rummel, 1970). For this study, factor analysis helped connect the value theory to e-government phenomena.

The multivariate statistical technique of factor analysis has found increased use (Hair, Anderson, Tatham, \& Black, 1998) for the purpose of interdependency and pattern delineation, data reduction, discovery of the basic structure, classification or description of variables, scaling, hypothesis testing, data transformation, exploration of the complex interrelations of phenomena, mapping of the social terrain, and theory building (Rummel, 1970). The common objective of factor analysis is to represent a set of variables in terms of a smaller number of hypothetical variables using various statistical methods (Kim \& Mueller, 1978). The primary functions of factor analysis for this study were to validate 
data and help determine empirically how many factors underlie a set of items (Devellis, 2003).

There are two types of factor analysis methods: exploratory and confirmatory factor analysis. The former was used because the purpose of this study was to discover the factor structure of a measure, and examine its internal reliability as opposed to confirming a particular pattern of relationships by a hypothesized factor structure (Devellis, 2003). The analysis examined the interrelationships among variables (egovernment objectives) using correlation coefficients as a measure of association. The correlation matrix was expected to reveal the structure of relationships among variables. Principal component analysis (PCA) was used for outlier detection. Outliers could cause data inconsistency that reflects a sample that behaves quite differently when comparing to other samples of the same group, and that could disqualify data analysis (Straub, 1989). PCA also was used to decide the number of factors. This study used PCA because the objective was to summarize most of the original variance in a minimum number of factors, as opposed to using common factor analysis (CFA) to identify underlying factors that reflect what the variables share in common (Hair et al., 1998). The basic assumption for this study was that the underlying structure of two variables, the means, and the fundamental objectives, were conceptually valid and appropriate. The outcome of factor analysis was two models of factor structures: one reflects means objectives, and the other reflects fundamental objectives. 


\section{Data Collection}

The population was all e-government service users. The sample for this study included working professionals from metropolitan areas in the United States who had experience in using e-government services. The target respondents were recruited from various professional sources, such as university alumni, bankers, lawyers, travel agents, accountants, IS engineers, and architects who expressed positive support for the study.

Response rate was a major issue in successful survey research. To increase response rate of its target population, this study attempted to minimize the respondents' effort in responding to the survey, and to maximize support from the population. To minimize the respondents' effort, the survey questions were made clear, concise, unambiguous, and consistent, and the responses can be made fast, less costly, and more convenient via Web survey. A major advantage of using Web survey for this study was to maximize convenience for the respondents because the target population (egovernment online users) was Web users who were equipped with the tools and knowledge of Web use. To maximize support from the population, the cooperation rate and the contact rate was considered (Langer, 2003). To increase the cooperation rate, participation of the survey was encouraged by stressing the participants' contribution to society in developing citizen centered e-government services and fostering e-democracy. To increase the contact rate, the target respondents were recruited from various professional sources who expressed positive support for the study. The expectation of the response rate was high, thus, the problem of nonresponse and its effects on this study was low. Though the expected responses were about 300, 210 responses were obtained. 
From two major types of sampling designs, probability and nonprobability sampling, this study used the probability sampling design because the representativeness of the sample was important in the interests of wider generalizability (Sekaran, 2000). The nonprobability sampling can be used when time or other factors rather than generalizability become critical (Sekaran, 2000). The sample for this study was working professionals from metropolitan areas in the United States who had experience in using egovernment services, reflecting the knowledge of computer use and access to Internet service. For a quantitative research such as the proposed, too small a sample size would not land the meaningful result whereas too large a sample size could reflect weak relationships in variables. As the sample sizes larger than 30 and less than 500 are appropriate for most research (Sekaran, 2000), the sample size for this study was 210.

Data collection methods are an integral part of research design each of which has its own advantages and disadvantages. Data can be collected from interviews by face-toface, telephone, and computer-mediated, questionnaires administered in person, mail, and electronic means, and observations with videotaping and audio recording. This study conducted on-line questionnaire surveys via the Web site by taking advantages of the electronic means: ease of administration, ease of reaching distanced respondents, inexpensive, fast, and flexible time for response. The disadvantages, such as requiring computer literacy and access to the facility, was overcome by selecting the samples who were capable in computer response and had access to Internet service.

The survey Web page presented users with radio buttons because the choices were mutually exclusive, which restricted them to selecting exactly one option for improved reliability. The respondents were asked to respond based on the best-described belief 
when they engage with e-government service. Further, when giving instructions to respondents, it was indicated that one's response should be relevant to the present experience and not reflect past experiences. Once the responses were entered via the survey Web page provided by SurveyMonkey.com, data were gathered electronically into the server for statistical analysis and validation using the SPSS software. A proper instruction that clearly identifies the research and presents the purpose of the survey was essential to facilitate the data collection. The instruction ended on a courteous note thanking the respondent for taking time to participate to the survey. Questionnaires were developed to avoid ambiguous, leading, loaded, and socially undesirable questions. In addition, simple, short questions were preferable to long ones, hence following a rule of thumb, the questionnaires (in a form of statement) were not exceeding 20 words (Sekaran, 2000). Questions were neatly and conveniently organized so that the respondent can conduct the survey with a minimum amount of time and effort. The following sample survey layout (see Figure 4) incorporates the points:

\section{E-government Experience Survey}

\begin{tabular}{lccccr}
\hline & $\begin{array}{c}\text { Strongly } \\
\text { Disagree }\end{array}$ & Disagree & Neutral & $\begin{array}{l}\text { Strongly } \\
\text { Agree }\end{array}$ \\
$\begin{array}{l}\text { I agree } \\
\text { information. } \\
\text { I am concerned about hackers. }\end{array}$ & $\mathrm{O}$ & $\mathrm{O}$ & $\mathrm{O}$ & $\mathrm{O}$ & $\mathrm{O}$ \\
$\begin{array}{l}\text { I am concerned about fraud when I want to purchase a product or } \\
\text { service from e-government sites. }\end{array}$ & $\mathrm{O}$ & $\mathrm{O}$ & $\mathrm{O}$ & $\mathrm{O}$ & $\mathrm{O}$ \\
$\begin{array}{l}\text { I like greater accessibility to information. } \\
\text { I feel there is sufficient transaction protection for e-government }\end{array}$ & $\mathrm{O}$ & $\mathrm{O}$ & $\mathrm{O}$ & $\mathrm{O}$ & $\mathrm{O}$ \\
$\begin{array}{l}\text { commerce. } \\
\text { I feel that e-government online transactions are speedy. }\end{array}$ & $\mathrm{O}$ & $\mathrm{O}$ & $\mathrm{O}$ & $\mathrm{O}$ & $\mathrm{O}$ \\
\end{tabular}


I feel there is sufficient security built into the Internet.

I am satisfied with the transaction speed.
$\mathrm{O} \quad \mathrm{O} \quad \mathrm{O} \quad \mathrm{O} \quad \mathrm{O}$

$\begin{array}{lllll}\mathrm{O} & \mathrm{O} & \mathrm{O} & \mathrm{O} & \mathrm{O}\end{array}$

Figure 4. Sample survey layout.

Prior to conducting the survey, a preliminary test for the survey procedure was conducted to confirm that the requirements were satisfied and the quality assurance of the survey function and resulting data were met. A test case was a specific scenario of the steps that respondents would normally take to respond the survey, from signing on to the survey Web site, browsing through the screens, entering the response, and leaving the Web site. In this process, the network and system response time was kept minimal to maintain the respondent's motivation. In addition, the background functions, such as capturing and storing data to the server, worked properly.

Data preparation was an important step for data analysis---a step that has a major impact on the success of an empirical study (Yu, Wang, \& Lai, 2006). Once data were collected from different samples, they were checked for inconsistencies and normalized to the format that could be used by the SPSS software for statistical analysis.

\section{Ethics in Data Collection}

The electronic survey was administered to working professionals (human subject) from metropolitan areas in the United States who had experience in using e-government services. Since this study involved human subjects, the design and conduct of research followed the guidelines to ensure their protection provided by the National Research Act 
Public Law 99-158, the Health Research Extension Act of 1985, and the National commission for the Protection of Human Subject of Biomedical and Behavioral Research (Nova Southeastern University, 2005). In general, it is considered unethical when the practices cause pressuring individuals to participate through coercion or applying social pressure, diminishing self-respect, deceiving subjects by deliberately misleading them, exposing participants to physical or mental stress, exposing respondents to hazardous environment, and not preserving the privacy and confidentiality of the information given by the participants (Sekaran, 2000). To ensure confidentiality, this study neither referred to outsiders nor maintained any form of linkage in order to go back and review the record at a later time. The only linkage information collected was the IP address of each respondent for the purpose of validating the integrity of the data source. As the respondents were somewhat geographically diversified, it was not expected that a great amount of responses derived from a single IP address. The list of IP addresses was permanently removed from the server once the validity test was complete. As it remained unknown who participated in the study, the likelihood of potential risks to the subjects was virtually none. The Institutional Review Board (IRB) approval letter from Nova Southeastern university for this survey research is attached in Appendix F.

\section{Time Horizon}

This study was a one-shot (cross sectional) instead of longitudinal study because data collection at one point in time was sufficient rather than two or more points in time to answer the research question. Data received between August and September in 2006 from the respondents will not be collected again from them for this research. 


\section{Unit of Analysis}

The unit of analysis refers to the level of aggregation of the data collected (Sekaran, 2000). As this study was interested in finding out the e-government value to citizens, the unit of analysis was the individual. Hence, the data collected from each individual was treated as an individual data source.

\section{Relating the Means and Ends Factors by Examining the Cross-correlations Among Factors}

The last step in developing instrument was to analyze the correlation matrix for convergent and discriminant validity. The magnitude of the correlations observed revealed the validity; items in one group were highly correlated with the other items in its group than with any of the items measuring other factors (Torkzadeh \& Dhillon, 2002).

\section{Resources}

In order to discuss the theoretical antecedents of e-government initiatives, measurement instruments, and framework, an extensive review of the literature from IS and other related journals, proceedings, and books on related topics was conducted. To illustrate the e-government phenomena, information collected by various public and private organizations were referenced. To complete the empirical study, a survey was administered to working professionals in the metropolitan area who have experiences in using the e-government services. Once data were collected, they were analyzed with the statistical software SPSS for validation. 


\section{Limitations and Barriers}

As new services and features continue to be added to e-government commerce, triggered by emerging technology and the ever-increasing demand for new services, governments continue their e-government march. A one-time study of the e-government phenomena is insufficient. Continued studies are needed to examine the progress and effectiveness of governments in delivering Web-based public services and facilitating citizens' Web-based political participation (Moon, 2002).

Since e-government encompasses various types of services for public users, with different abilities and rights, it faces various issues in providing services. Examples of the issues are accessibility related to digital divide through cost, availability, and sensory impairment and constituencies related to e-democratic diversity through geographical boundaries and voting rights (French, 2003). Values for these types of unique situations are specific and large enough to demand separate research. Though the proposed research addressed the e-government services at some level of specificity, it mainly focused on general issues instead of a variety of service-specific issues.

Several governments lack the fundamental infrastructure, organizational culture, understanding, and resources for a transformation of the magnitude that e-governments require (Devadoss et al., 2002). Therefore, the basis of comparison might be invalid if those comparable systems are achieving less-than-desirable results due to factors unique to their context (Grover, Keong, \& Segars, 1996). For example, a local government's ITcentered innovation is influenced by public organizations and the public policy process, such as a higher degree of control by the external environment and administrative authorities (Kim \& Bretschneider, 2004). In addition, a study (Holden, Norris, \& 
Fletcher, 2003) found that that five greatest barriers to the adoption of e-government are lack of technology or Web staff, lack of financial resources, lack of technology or Web expertise, issues regarding security, and the need to upgrade existing information technology.

The instrument development for eliciting responses from subjects for this study reflected one country. With the globalization of e-government implementations, the research effort will need to trace the similarities and differences in the behavioral and attitudinal responses of e-government users at various levels in difference countries. Certain special issues need to be addressed while designing instruments for collecting data by each country or from different counties that include vocabulary equivalence, idiomatic equivalence, conceptual equivalence, and response equivalence (Sekaran, 2000).

Measuring of research constructs is neither simple nor straightforward (Straub, 1989). Due to the inherent nature of conducting user surveys, this study would have a certain amount of bias. The choice of method (as in online versus off-line instruments) and components of the chosen method (as in item selection and item phrasing) could have affected instrumentation. Inaccuracies in measurement could be reflected in the instrument when items were ambiguously phrased, length of the instrument taxed respondents' concentration, or motivation for answering carefully was not induced (Straub, 1989).

Different e-government users might view the value of the same e-government services differently. One may have found it convenient, easy to use, and low-cost, while other experienced the e-government service over the Internet as overly difficult and 
impersonal. Thus, the net value including benefits and costs of ordering and receiving the services could significantly differ by individual. In addition, measuring instruments are not static in nature; they evolve through an ever-changing refinement. Hence, the instruments developed in this study will need to be refined in the future as technology and services emerge.

Correlation is a linear measure of association between the variables. The correlation can be observed by assessing the variations in one variable as another variable also varies (Sekaran, 2000). Though the zero correlation coefficient value indicates no strength of the association between two variables (Hair et al., 1998), it does not imply that there is no relationship at all; it only means that there is no linear relationship between them. For example, the correlation between $\mathrm{y}$ and $\mathrm{x}$ would be zero, even though they are perfectly related: $y=\sin (x)$. Hence, correlation is adequate if the relationship is monotonically increasing or decreasing.

\section{Summary}

This chapter delineated the methodology and activities for conducting the study. In order to develop a basis for formulating a model of e-government value for empirical study, a list of e-government objectives from the exploratory study by Torkzadeh and Dhillon (2002) and the published research pool during the 6-year period from 2000 to 2005 was generated. The e-government objectives then were grouped into two categories, means and ends (fundamental) objectives. Based on this categorization, two instruments that together measure the factors that influence the success of e-government initiatives was developed. One instrument measures the means objectives that influence using e- 
government services, and the other measures the fundamental objectives that are essential reasons for using e-government services. In addition, the instrument development and validation steps were addressed.

The components of empirical research design included type of investigation, extent of interference, measurement type, data-collection method, time horizon, sampling design, and unit of analysis. The instrument validation included content validity, construct validity and reliability. Ethics of data collection concerned the respondent's privacy and security.

There were various limitations and barriers for the research. One-time study of egovernment phenomena is insufficient; on-going studies are needed to examine the progress and implications of the e-government evolution. Since e-government encompasses various types of services for public use, each with its own set of issues and complexities, a wide range of research is required. Thus, this research will address the different e-government services at some level of specificity, while also providing an overview of general issues. The instruments developed in this study will need to be refined in the future as new technologies and services emerge. 


\section{Chapter 4}

\section{Results}

\section{Data Analysis for Means Objectives}

\section{Descriptive Statistics}

The output from the descriptive statistics (Table 9) from the total of 210 survey responses indicated that all 48 items were perceived to be relevant because the mean values for most of the items were either 4 or 5, reflecting the answers of "agree" and "strongly agree." Though nine items had mean values of less than 4 , as the values were close to 4 (3.68 through 3.98), they were not eliminated. The three most important items, with the highest mean of 4.69 , were concerns about hacking, identity theft and safeguarding of personal information. The least significant item, with the lowest mean of 3.68 , was the variety of foreign language options available to people.

Table 9

Descriptive Statistics for Means Objectives $(N=210)$

\begin{tabular}{|c|c|c|c|c|}
\hline Item & Min & Max & Mean & $\begin{array}{l}\text { Std. } \\
\text { Deviation }\end{array}$ \\
\hline I like the opportunity for two-way interaction. & 1 & 5 & 4.35 & .634 \\
\hline I like the opportunity for personal interaction. & 1 & 5 & 4.10 & .800 \\
\hline $\begin{array}{l}\text { I feel it is important to improve communication between } \\
\text { the government and its citizens. }\end{array}$ & 1 & 5 & 4.52 & .635 \\
\hline $\begin{array}{l}\text { I like to promote universal access that will allow all citizens } \\
\text { to easily and conveniently interact with e-government. }\end{array}$ & 1 & 5 & 4.22 & .788 \\
\hline $\begin{array}{l}\text { I like to minimize the digital divide demarcated by wealth, } \\
\text { age, language, culture, geographical location, etc. }\end{array}$ & 1 & 5 & 4.14 & .869 \\
\hline $\begin{array}{l}\text { I feel accessibility for individuals with special needs } \\
\text { (e.g., disabilities) should be maximized. }\end{array}$ & 1 & 5 & 4.18 & .790 \\
\hline I like to participate electronically and directly in decision making. & 1 & 5 & (3.92) & .823 \\
\hline
\end{tabular}


Table 9 (continued)

\begin{tabular}{|c|c|c|c|c|}
\hline Item & Min & Max & Mean & $\begin{array}{l}\text { Std. } \\
\text { Deviation }\end{array}$ \\
\hline I like to voice my preferences regarding policies. & 2 & 5 & (3.94) & .710 \\
\hline $\begin{array}{l}\text { I like to promote knowledge sharing between } \\
\text { the government and its citizens. }\end{array}$ & 2 & 5 & 4.21 & .675 \\
\hline $\begin{array}{l}\text { I like to promote e-services (e.g., voting online, } \\
\text { discussing public issues online, etc.). }\end{array}$ & 1 & 5 & 3.93 & .894 \\
\hline I am concerned about how much I can trust the government. & 1 & 5 & 4.05 & .882 \\
\hline I like to promote transparency in government. & 2 & 5 & 4.22 & .740 \\
\hline I like to promote fairness, providing non-discriminatory service. & 1 & 5 & 4.40 & .727 \\
\hline I like to promote public outreach. & 2 & 5 & 4.14 & .688 \\
\hline $\begin{array}{l}\text { I like to have horizontal integration of government services } \\
\text { (linking different functions of government with each other). }\end{array}$ & 1 & 5 & $(3.96)$ & .769 \\
\hline $\begin{array}{l}\text { I like to have vertical integration of government services } \\
\text { (linking different levels of government, such as local, state, } \\
\text { and federal). }\end{array}$ & 1 & 5 & 3.90 & .869 \\
\hline I like to facilitate information dissemination. & 2 & 5 & (3.98) & .754 \\
\hline I like to have information on demand. & 1 & 5 & 4.32 & .663 \\
\hline I like to have search criteria. & 1 & 5 & 4.20 & 699 \\
\hline I like to have a great amount of information. & 2 & 5 & 4.04 & .778 \\
\hline I like to have up-to-date information. & 2 & 5 & 4.54 & .580 \\
\hline I like to have a choice of information. & 1 & 5 & 4.35 & .634 \\
\hline I like to minimize the risk of skipping or missing information. & 2 & 5 & 4.27 & .676 \\
\hline I like to get as much information about services as possible. & 2 & 5 & 4.20 & .737 \\
\hline I like seeing greater use of style and format in Web site design. & 1 & 5 & $(3.76)$ & .882 \\
\hline $\begin{array}{l}\text { I like to make e-government services more appealing } \\
\text { to the average person. }\end{array}$ & 1 & 5 & 4.01 & .792 \\
\hline I like to promote ease of viewing. & 2 & 5 & 4.24 & .721 \\
\hline $\begin{array}{l}\text { I like to have a variety of foreign language options } \\
\text { available to people. }\end{array}$ & 1 & 5 & $(3.68)$ & 1.075 \\
\hline $\begin{array}{l}\text { I like to have e-government systems agreeing and implementing } \\
\text { global standards (e.g., e-signature identification). }\end{array}$ & 1 & 5 & $(3.90)$ & .842 \\
\hline
\end{tabular}


Table 9 (continued)

\begin{tabular}{|c|c|c|c|c|}
\hline Item & Min & Max & Mean & $\begin{array}{l}\text { Std. } \\
\text { Deviation }\end{array}$ \\
\hline I like to discourage unauthorized access. & 1 & 5 & 4.55 & 678 \\
\hline I like to discourage hacking. & 1 & 5 & 4.69 & 652 \\
\hline I am concerned about transaction security. & 1 & 5 & 4.62 & .690 \\
\hline I am concerned about misuse of my credit card. & 1 & 5 & 4.68 & .704 \\
\hline I am concerned about identity theft. & 1 & 5 & 4.69 & .668 \\
\hline I am concerned about privacy risks. & 1 & 5 & 4.64 & .713 \\
\hline I am concerned about the safeguarding of personal information. & 1 & 5 & 4.69 & .682 \\
\hline I am concerned about sharing of personal information. & 1 & 5 & 4.59 & .767 \\
\hline I am concerned about receiving unsolicited material. & 1 & 5 & 4.39 & .807 \\
\hline I am concerned about reliable delivery of information and services. & 1 & 5 & 4.34 & .703 \\
\hline $\begin{array}{l}\text { I am concerned about quality of the information and } \\
\text { services delivered. }\end{array}$ & 1 & 5 & 4.32 & .718 \\
\hline I am concerned about accuracy of transaction. & 1 & 5 & 4.49 & 693 \\
\hline I am concerned about charging errors. & 1 & 5 & 4.40 & .765 \\
\hline I like to have new types of services. & 1 & 5 & $(3.87)$ & .817 \\
\hline $\begin{array}{l}\text { I feel that new services should be made as convenient } \\
\text { as possible utilizing various devices, such as cell phones, } \\
\text { PDAs, etc. }\end{array}$ & 1 & 5 & $(3.81)$ & .934 \\
\hline I feel ease of accessing information and services is important. & 1 & 5 & 4.31 & .667 \\
\hline I feel ease of search process is important. & 1 & 5 & 4.35 & 662 \\
\hline I feel ease of use for information and services is important. & 1 & 5 & 4.33 & 636 \\
\hline $\begin{array}{l}\text { I like to have compatibility between e-government services } \\
\text { and older "legacy" services (e.g., paper based system). }\end{array}$ & 1 & 5 & 4.14 & .823 \\
\hline
\end{tabular}




\section{Item Purification and Reliability Test}

The item purification process resulted in removing nine items. Eight items were removed because the correlation coefficients were below 0.05 , reflecting low correlation (see the "Corrected Item-Total Correlation" column in Table 10). Another item was removed because the correlation coefficient was extremely high (greater than 0.90 ), which could cause a problem because of singularity. The deleted items were related to opportunity for personal interaction, participation in decision making, voicing my preferences regarding policies, promoting e-services, trusting government, vertical integration of government services, offering foreign language services, implementing global standards, and choice of information. The remaining 39 items reflected high correlation between measures of the same construct; thus, constructs were considered valid (Straub, 1989).

Table 10

Item-Total Statistics for Means Objectives

\begin{tabular}{|c|c|c|c|}
\hline Item & $\begin{array}{l}\text { Scale } \\
\text { Mean if } \\
\text { Item } \\
\text { Deleted }\end{array}$ & $\begin{array}{l}\text { Scale } \\
\text { Variance } \\
\text { if Item } \\
\text { Deleted }\end{array}$ & $\begin{array}{l}\text { Corrected } \\
\text { Item-Total } \\
\text { Correlation }\end{array}$ \\
\hline I like the opportunity for two-way interaction. & 199.24 & 413.678 & 677 \\
\hline I like the opportunity for personal interaction. & 199.49 & 418.921 & $(.365)$ \\
\hline $\begin{array}{l}\text { I feel it is important to improve communication between } \\
\text { the government and its citizens. }\end{array}$ & 199.07 & 416.909 & .548 \\
\hline $\begin{array}{l}\text { I like to promote universal access that will allow all } \\
\text { citizens to easily and conveniently interact with e- } \\
\text { government. }\end{array}$ & 199.38 & 410.791 & .629 \\
\hline $\begin{array}{l}\text { I like to minimize the digital divide demarcated by wealth, } \\
\text { age, language, culture, geographical location, etc. }\end{array}$ & 199.45 & 411.971 & .533 \\
\hline
\end{tabular}


Table 10 (continued)

\begin{tabular}{|c|c|c|c|}
\hline Item & $\begin{array}{l}\text { Scale } \\
\text { Mean if } \\
\text { Item } \\
\text { Deleted }\end{array}$ & $\begin{array}{l}\text { Scale } \\
\text { Variance } \\
\text { if Item } \\
\text { Deleted }\end{array}$ & $\begin{array}{l}\text { Corrected } \\
\text { Item-Total } \\
\text { Correlation }\end{array}$ \\
\hline $\begin{array}{l}\text { I feel accessibility for individuals with special needs (e.g., } \\
\text { disabilities) should be maximized. }\end{array}$ & 199.42 & 411.489 & .606 \\
\hline $\begin{array}{l}\text { I like to participate electronically and directly in decision } \\
\text { making. }\end{array}$ & 199.68 & 418.057 & $(.380)$ \\
\hline I like to voice my preferences regarding policies. & 199.65 & 421.692 & $(.320)$ \\
\hline $\begin{array}{l}\text { I like to promote knowledge sharing between the } \\
\text { government and its citizens. }\end{array}$ & 199.38 & 416.687 & .522 \\
\hline $\begin{array}{l}\text { I like to promote e-services (e.g., voting online, } \\
\text { discussing public issues online, etc.) }\end{array}$ & 199.66 & 414.311 & $(.451)$ \\
\hline $\begin{array}{l}\text { I am concerned about how much I can trust the } \\
\text { government. }\end{array}$ & 199.54 & 416.335 & $(.401)$ \\
\hline I like to promote transparency in government. & 199.37 & 415.660 & .508 \\
\hline $\begin{array}{l}\text { I like to promote fairness, providing non-discriminatory } \\
\text { service. }\end{array}$ & 199.20 & 413.871 & .579 \\
\hline I like to promote public outreach. & 199.46 & 414.163 & .603 \\
\hline $\begin{array}{l}\text { I like to have horizontal integration of government } \\
\text { services (linking different functions of government with } \\
\text { each other). }\end{array}$ & 199.63 & 413.133 & .569 \\
\hline $\begin{array}{l}\text { I like to have vertical integration of government services } \\
\text { (linking different levels of government, such as local, } \\
\text { state, and federal). }\end{array}$ & 199.70 & 414.067 & $(.472)$ \\
\hline I like to facilitate information dissemination. & 199.62 & 413.136 & .581 \\
\hline I like to have information on demand. & 199.27 & 415.270 & .585 \\
\hline I like to have search criteria. & 199.39 & 413.474 & .618 \\
\hline I like to have a great amount of information. & 199.55 & 414.153 & .529 \\
\hline I like to have up-to-date information. & 199.06 & 415.719 & .655 \\
\hline I like to have a choice of information. & 199.24 & 413.678 & .677 \\
\hline $\begin{array}{l}\text { I like to minimize the risk of skipping or missing } \\
\text { information. }\end{array}$ & 199.32 & 415.196 & .576 \\
\hline
\end{tabular}


Table 10 (continued)

\begin{tabular}{|c|c|c|c|}
\hline Item & $\begin{array}{l}\text { Scale } \\
\text { Mean if } \\
\text { Item } \\
\text { Deleted }\end{array}$ & $\begin{array}{l}\text { Scale } \\
\text { Variance } \\
\text { if Item } \\
\text { Deleted }\end{array}$ & $\begin{array}{l}\text { Corrected } \\
\text { Item-Total } \\
\text { Correlation }\end{array}$ \\
\hline $\begin{array}{l}\text { I like to get as much information about services as } \\
\text { possible. }\end{array}$ & 199.40 & 412.776 & .608 \\
\hline $\begin{array}{l}\text { I like seeing greater use of style and format in Web site } \\
\text { design. }\end{array}$ & 199.84 & 412.155 & .519 \\
\hline $\begin{array}{l}\text { I like to have a variety of foreign language options } \\
\text { available to people. }\end{array}$ & 199.91 & 413.026 & $(.397)$ \\
\hline $\begin{array}{l}\text { I like to have e-government systems agreeing and } \\
\text { implementing global standards (e.g., e-signature } \\
\text { identification). }\end{array}$ & 199.69 & 414.473 & $(.477)$ \\
\hline I like to discourage unauthorized access. & 199.05 & 416.467 & .528 \\
\hline I like to discourage hacking. & 198.90 & 416.804 & .537 \\
\hline I am concerned about transaction security. & 198.98 & 413.736 & .617 \\
\hline I am concerned about misuse of my credit card. & 198.91 & 416.127 & .519 \\
\hline I am concerned about identity theft. & 198.91 & 416.494 & .535 \\
\hline I am concerned about privacy risks. & 198.95 & 415.175 & .545 \\
\hline $\begin{array}{l}\text { I am concerned about the safeguarding of personal } \\
\text { information. }\end{array}$ & 198.91 & 415.815 & .548 \\
\hline I am concerned about sharing of personal information. & 199.01 & 414.785 & .517 \\
\hline I am concerned about receiving unsolicited material. & 199.20 & 414.049 & .513 \\
\hline $\begin{array}{l}\text { I am concerned about reliable delivery of information and } \\
\text { services. }\end{array}$ & 199.25 & 412.266 & .657 \\
\hline $\begin{array}{l}\text { I am concerned about quality of the information and } \\
\text { services delivered. }\end{array}$ & 199.28 & 412.115 & .649 \\
\hline I am concerned about accuracy of transaction. & 199.11 & 414.155 & .598 \\
\hline I am concerned about charging errors. & 199.20 & 414.993 & .512 \\
\hline
\end{tabular}


Table 10 (continued)

\begin{tabular}{|c|c|c|c|}
\hline Item & $\begin{array}{c}\text { Scale } \\
\text { Mean if } \\
\text { Item } \\
\text { Deleted }\end{array}$ & $\begin{array}{c}\text { Scale } \\
\text { Variance } \\
\text { if Item } \\
\text { Deleted }\end{array}$ & $\begin{array}{l}\text { Corrected } \\
\text { Item-Total } \\
\text { Correlation }\end{array}$ \\
\hline I like to have new types of services. & 199.72 & 409.713 & .639 \\
\hline $\begin{array}{l}\text { I feel that new services should be made as convenient as } \\
\text { possible utilizing various devices, such as cell phones, } \\
\text { PDAs, etc. }\end{array}$ & 199.79 & 409.566 & .558 \\
\hline $\begin{array}{l}\text { I feel ease of accessing information and services is } \\
\text { important. }\end{array}$ & 199.29 & 411.459 & .726 \\
\hline I feel ease of search process is important. & 199.25 & 410.847 & .754 \\
\hline $\begin{array}{l}\text { I feel ease of use for information and services is } \\
\text { important. }\end{array}$ & 199.26 & 412.156 & .734 \\
\hline $\begin{array}{l}\text { I like to have compatibility between e-government } \\
\text { services and older "legacy" services (e.g., paper based } \\
\text { system). }\end{array}$ & 199.45 & 410.880 & .598 \\
\hline
\end{tabular}

\section{Dimensionality}

To address the dimensionality of the remaining constructs, the Kaiser-MeyerOlkin (KMO) measure of sampling adequacy was used. The KMO measure of 0.925 (see Figure 5) was large enough to proceed with factor analysis, as the extracted factors would account for a substantial amount of variance. Therefore, the factor solution generated was reliable.

The observed significance level for Bartlett's test of sphericity was 0.000 (see Figure 5), indicating that the relationship among variables was strong. Thus, factor analysis was appropriate. 
KMO and Bartlett's Test

\begin{tabular}{|c|c|c|}
\hline \multicolumn{2}{|c|}{$\begin{array}{l}\text { Kaiser-Meyer-Olkin Measure of Sampling } \\
\text { Adequacy. }\end{array}$} & .925 \\
\hline $\begin{array}{l}\text { Bartlett's Test of } \\
\text { Sphericity }\end{array}$ & $\begin{array}{l}\text { Approx. Chi-Square } \\
\text { df } \\
\text { Sig. }\end{array}$ & $\begin{array}{r}6306.091 \\
741 \\
.000\end{array}$ \\
\hline
\end{tabular}

Figure 5. KMO and Bartlett's test for means objectives.

\section{Factor Analysis (Principal Component Analysis)}

The exploratory factor analysis using principal component analysis (PCA) identified outliers and extracted four components (factors) while reducing the number of variables. Before a factor solution was generated, the communality values were evaluated in order to select the items that account for at least half of the variance in the variables by the extracted factors. The first iteration of the PCA computing without specifying the number of factors resulted in removing one item for which the communality value was less then 0.5 , reflecting that it accounted for less than $50 \%$ of the variance in the variables. The removed item was "I like to have compatibility between egovernment services and older 'legacy' services (e.g., paper based system)." The second iteration resulted in no further deletion of items. The table of communalities from the second iteration (Table 11) showed the remaining 38 items that were used to examine the pattern of factor loadings. Table 11 indicated that the items with the least (53.6\%) and the most $(89.8 \%)$ accounted for were "I like to promote transparency in government." and "I am concerned about the safeguarding of personal information," respectively. 


\section{Table 11}

\section{Communalities for Means Objectives}

\begin{tabular}{|c|c|c|}
\hline Item & Initial & Extraction \\
\hline I like the opportunity for two-way interaction. & 1.000 & .597 \\
\hline $\begin{array}{l}\text { I feel it is important to improve communication between } \\
\text { the government and its citizens. }\end{array}$ & 1.000 & .569 \\
\hline $\begin{array}{l}\text { I like to promote universal access that will allow all } \\
\text { citizens to easily and conveniently interact with e- } \\
\text { government. }\end{array}$ & 1.000 & .593 \\
\hline $\begin{array}{l}\text { I like to minimize the digital divide demarcated by } \\
\text { wealth, age, language, culture, geographical location, } \\
\text { etc. }\end{array}$ & 1.000 & .661 \\
\hline $\begin{array}{l}\text { I feel accessibility for individuals with special needs } \\
\text { (e.g., disabilities) should be maximized. }\end{array}$ & 1.000 & .700 \\
\hline $\begin{array}{l}\text { I like to promote knowledge sharing between the } \\
\text { government and its citizens. }\end{array}$ & 1.000 & .589 \\
\hline I like to promote transparency in government. & 1.000 & .536 \\
\hline $\begin{array}{l}\text { I like to promote fairness, providing non-discriminatory } \\
\text { service. }\end{array}$ & 1.000 & .701 \\
\hline I like to promote public outreach. & 1.000 & .698 \\
\hline $\begin{array}{l}\text { I like to have horizontal integration of government } \\
\text { services (linking different functions of government with } \\
\text { each other). }\end{array}$ & 1.000 & .546 \\
\hline I like to facilitate information dissemination. & 1.000 & .646 \\
\hline I like to have information on demand. & 1.000 & .692 \\
\hline I like to have search criteria. & 1.000 & .703 \\
\hline I like to have a great amount of information. & 1.000 & .663 \\
\hline I like to have up-to-date information. & 1.000 & .597 \\
\hline $\begin{array}{l}\text { I like to minimize the risk of skipping or missing } \\
\text { information. }\end{array}$ & 1.000 & .688 \\
\hline $\begin{array}{l}\text { I like to get as much information about services as } \\
\text { possible. }\end{array}$ & 1.000 & .740 \\
\hline I like seeing greater use of style and format in Web si & 1.000 & .666 \\
\hline
\end{tabular}
design. 
Table 11 (continued)

\begin{tabular}{|c|c|c|}
\hline Item & Initial & Extraction \\
\hline $\begin{array}{l}\text { I like to make e-government services more appealing to } \\
\text { the average person. }\end{array}$ & 1.000 & .682 \\
\hline I like to promote ease of viewing. & 1.000 & .611 \\
\hline I like to discourage unauthorized access. & 1.000 & .651 \\
\hline I like to discourage hacking. & 1.000 & .722 \\
\hline I am concerned about transaction security. & 1.000 & .840 \\
\hline I am concerned about misuse of my credit card. & 1.000 & .817 \\
\hline I am concerned about identity theft. & 1.000 & .885 \\
\hline I am concerned about privacy risks. & 1.000 & .881 \\
\hline $\begin{array}{l}\text { I am concerned about the safeguarding of personal } \\
\text { information. }\end{array}$ & 1.000 & .898 \\
\hline I am concerned about sharing of personal information. & 1.000 & .705 \\
\hline I am concerned about receiving unsolicited material. & 1.000 & .550 \\
\hline $\begin{array}{l}\text { I am concerned about reliable delivery of information } \\
\text { and services. }\end{array}$ & 1.000 & .808 \\
\hline $\begin{array}{l}\text { I am concerned about quality of the information and } \\
\text { services delivered. }\end{array}$ & 1.000 & .807 \\
\hline I am concerned about accuracy of transaction. & 1.000 & .810 \\
\hline I am concerned about charging errors. & 1.000 & .598 \\
\hline I like to have new types of services. & 1.000 & .642 \\
\hline $\begin{array}{l}\text { I feel that new services should be made as convenient } \\
\text { as possible utilizing various devices, such as cell } \\
\text { phones, PDAs, etc. }\end{array}$ & 1.000 & .582 \\
\hline $\begin{array}{l}\text { I feel ease of accessing information and services is } \\
\text { important. }\end{array}$ & 1.000 & .717 \\
\hline I feel ease of search process is important. & 1.000 & .713 \\
\hline $\begin{array}{l}\text { I feel ease of use for information and services is } \\
\text { important. }\end{array}$ & 1.000 & .707 \\
\hline
\end{tabular}

Extraction Method: Principal Component Analysis. 
To detect outliers, the regression equation was used to calculate the factor scores where cases with the factor scores either greater than 3.0 or smaller than -3.0 were identified. Twelve cases identified as outliers. Excluding these outliers, the remaining 198 cases were used to extract components.

To extract the principal components, the Varimax rotation with Kaiser normalization method was used. The first iteration of rotation without specifying the number of factors resulted in nine components with the eigenvalues greater than one, but this solution did not make sense. The 4-factor solution was chosen because it made the best sense. However, this model presented 11 items for which the communality values were less then 0.5 , reflecting that each one accounted for less than $50 \%$ of the variance in the variables. Thus, they were removed. The removed items were related to improving communication, knowledge sharing, transparency in government, non-discriminatory service, horizontal integration of government, facilitating information dissemination, use of style and format in Web site design, unauthorized access, discouraging hacking, unsolicited material, and charging errors. The second iteration removed another three items for which the communality values were less than 0.5 . The removed items were related to universal access, appealing to the average person, and ease of use. The third iteration removed one item for which the communality value was less than 0.5 . The removed item was related to ease of viewing. The fourth iteration represented all 23 items with the communality value greater than 0.5 and presented a 4 -componet (factor) solution that was not difficult to interpret. These four components explained more than $60 \%$ of the cumulative variance (see Figure 6), which was ideal for factor analysis. The four components accounted for $64.738 \%$ of the total variances where the first factor 
accounts for $37.421 \%$, the second $14.721 \%$, the third $6.809 \%$, and the fourth $5.788 \%$.

The remaining factors were not considered significant. The scree plot (see Figure 7) also supported the 4-factor model in that the curve began to flatten from the $5^{\text {th }}$ component.

\begin{tabular}{|c|c|c|c|c|c|c|c|c|c|}
\hline \multirow[b]{2}{*}{ Component } & \multicolumn{3}{|c|}{ Initial Eigenvalues } & \multicolumn{3}{|c|}{$\begin{array}{l}\text { Extraction Sums of Squared } \\
\text { Loadings }\end{array}$} & \multicolumn{3}{|c|}{$\begin{array}{c}\text { Rotation Sums of Squared } \\
\text { Loading }\end{array}$} \\
\hline & Total & $\begin{array}{c}\% \text { of } \\
\text { Variance }\end{array}$ & $\begin{array}{c}\text { Cumulative } \\
\%\end{array}$ & Total & $\begin{array}{c}\% \text { of } \\
\text { Variance } \\
\end{array}$ & $\begin{array}{c}\text { Cumulative } \\
\%\end{array}$ & Total & $\begin{array}{c}\% \text { of } \\
\text { Variance }\end{array}$ & $\begin{array}{c}\text { Cumulative } \\
\%\end{array}$ \\
\hline 1 & 8.607 & 37.421 & 37.421 & 8.607 & 37.421 & 37.421 & 4.750 & 20.650 & 20.650 \\
\hline 2 & 3.386 & 14.721 & 52.142 & 3.386 & 14.721 & 52.142 & 4.518 & 19.642 & 40.293 \\
\hline 3 & 1.566 & 6.809 & 58.951 & 1.566 & 6.809 & 58.951 & 2.920 & 12.696 & 52.989 \\
\hline 4 & 1.331 & 5.788 & 64.738 & 1.331 & 5.788 & 64.738 & 2.702 & 11.750 & 64.738 \\
\hline 5 & .923 & 4.014 & 68.752 & & & & & & \\
\hline 6 & .860 & 3.739 & 72.491 & & & & & & \\
\hline 7 & .774 & 3.366 & 75.857 & & & & & & \\
\hline 8 & .673 & 2.927 & 78.785 & & & & & & \\
\hline 9 & .586 & 2.550 & 81.334 & & & & & & \\
\hline 10 & .560 & 2.436 & 83.771 & & & & & & \\
\hline 11 & .459 & 1.995 & 85.765 & & & & & & \\
\hline 12 & .420 & 1.828 & 87.593 & & & & & & \\
\hline 13 & .404 & 1.757 & 89.350 & & & & & & \\
\hline 14 & .384 & 1.671 & 91.021 & & & & & & \\
\hline 15 & .360 & 1.567 & 92.588 & & & & & & \\
\hline 16 & .325 & 1.412 & 94.000 & & & & & & \\
\hline 17 & .279 & 1.214 & 95.214 & & & & & & \\
\hline 18 & .262 & 1.141 & 96.355 & & & & & & \\
\hline 19 & .243 & 1.056 & 97.411 & & & & & & \\
\hline 20 & .200 & .871 & 98.282 & & & & & & \\
\hline 21 & .150 & .652 & 98.934 & & & & & & \\
\hline 22 & .141 & .613 & 99.547 & & & & & & \\
\hline 23 & .104 & .453 & 100.000 & & & & & & \\
\hline
\end{tabular}

Extraction Method: Principal Component Analysis.

Figure 6. Total variance explained for means objectives. 
Scree Plot

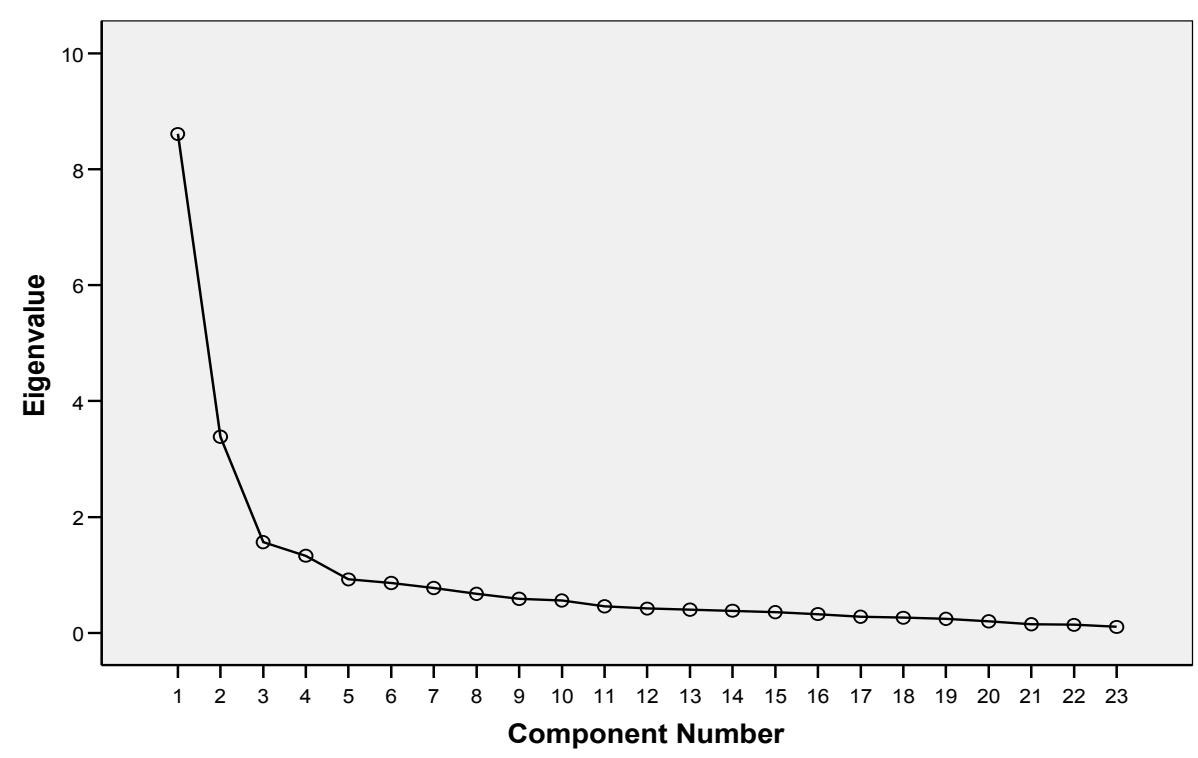

Figure 7. Scree plot for means objectives.

To address the unrotated factor solution, the unrotated 4-factor model was inadequate to interpret as it did not provide a meaningful pattern of the variable loadings. The unrotated solution indicated that the first factor was a general factor for which most variables were loaded highly while the subsequent factors were based on the residual amount of variance (Hair et al., 1998) for which the relatively small number of variables were loaded. Factor rotation achieved a more meaningful pattern of the variable loadings by redistributing the variance, which helped in interpreting factors. The component plot in rotated space (see Figure 8) reflected that the relative importance of the factors was equalized and that the factor loadings were plotted in the relatively high end of the axes. 


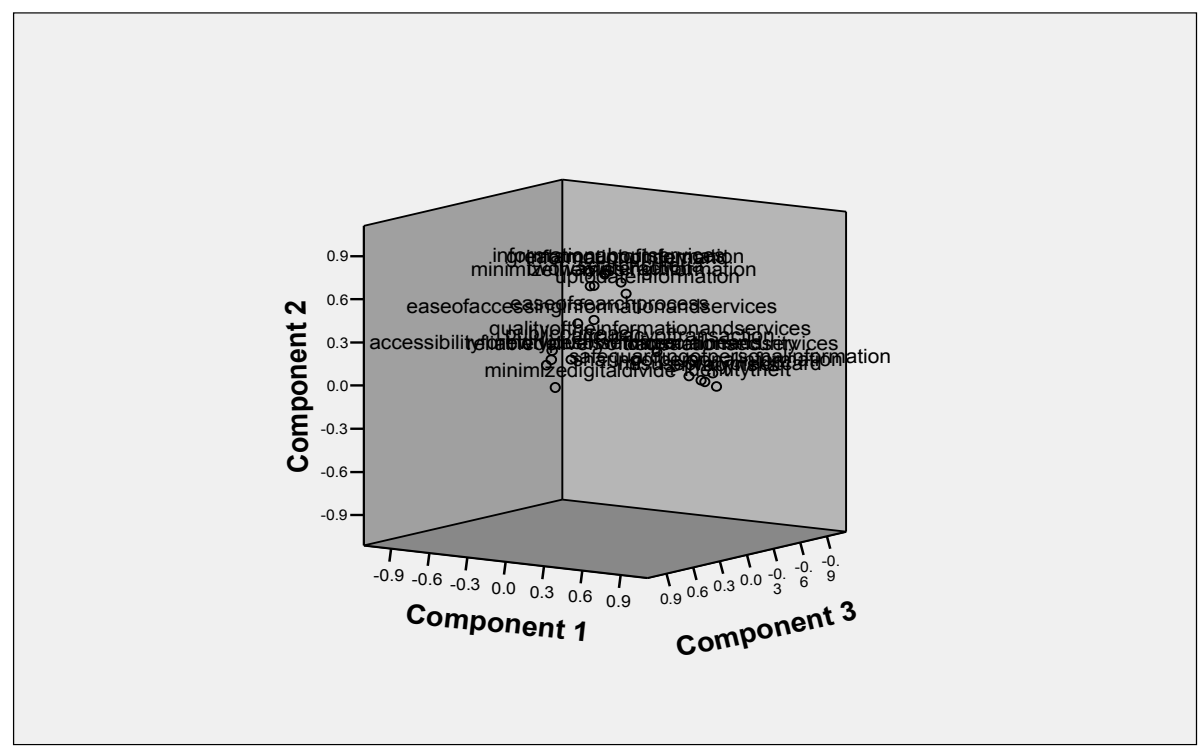

Figure 8. Component plot in rotated space for means objectives.

The rotated component matrix (see Figure 9) presented the four components with associated variables sorted by size of the factor loadings. The factor loadings of selected items were in parenthesis. The higher the factor loadings, the more it contributed to the variable and the stronger the variable correlated with the factor. Three items were excluded from this solution. Two of the items resulted in low loadings (less than 0.5) and one item resulted in a high loading (greater than 0.5 ) on multiple factors reflecting that they were not factorially pure. These items were related to ease of search, ease of access information and services, and promoting new type of services. The first group of variables was loaded from 0.687 to 0.890 , the second group from 0.638 to 0.764 , the third from 0.590 to 0.759 , and the fourth from 0.708 to 0.831 . The 4 -factor model was not 
difficult to interpret, corresponding with public trust (six items), information access

(seven items), public accessibility (four items), and quality of service (three items).

\begin{tabular}{|c|c|c|c|c|}
\hline & \multicolumn{4}{|c|}{ Component } \\
\hline & 1 & 2 & 3 & 4 \\
\hline I am concerned about identity theft. & $(.897)$ & .040 & .032 & .149 \\
\hline $\begin{array}{l}\text { I am concerned about the safeguarding of personal } \\
\text { information. }\end{array}$ & $(.890)$ & .137 & .065 & .108 \\
\hline I am concerned about privacy risks. & $(.874)$ & .086 & .131 & .114 \\
\hline I am concerned about misuse of my credit card. & $(.816)$ & .084 & .088 & .124 \\
\hline I am concerned about transaction security. & $(.778)$ & .228 & .134 & .182 \\
\hline $\begin{array}{l}\text { I am concerned about sharing of personal } \\
\text { information. }\end{array}$ & $(.687)$ & .093 & .040 & .213 \\
\hline $\begin{array}{l}\text { I like to get as much information about services as } \\
\text { possible. }\end{array}$ & -.008 & $(.764)$ & .157 & .229 \\
\hline I like to have information on demand. & .100 & $(.755)$ & 145 & .017 \\
\hline I like to have a great amount of information. & .049 & $(.750)$ & .072 & .086 \\
\hline I like to have search criteria. & .230 & $(.714)$ & 149 & .044 \\
\hline I like the opportunity for two-way interaction. & .088 & $(.691)$ & .247 & .204 \\
\hline $\begin{array}{l}\text { I like to minimize the risk of skipping or missing } \\
\text { information. }\end{array}$ & .031 & $(.676)$ & .210 & .219 \\
\hline I like to have up-to-date information. & .266 & $(.638)$ & .144 & .175 \\
\hline I feel ease of search process is important. & .220 & .493 & .437 & .317 \\
\hline $\begin{array}{l}\text { I feel ease of accessing information and services is } \\
\text { important. }\end{array}$ & .108 & .460 & .459 & .352 \\
\hline $\begin{array}{l}\text { I feel accessibility for individuals with special needs } \\
\text { (e.g., disabilities) should be maximized. }\end{array}$ & .110 & .252 & $(.759)$ & .028 \\
\hline $\begin{array}{l}\text { I like to minimize the digital divide demarcated by } \\
\text { wealth, age, language, culture, geographical } \\
\text { location, etc. }\end{array}$ & .126 & .057 & $(.736)$ & .035 \\
\hline I like to promote public outreach. & .085 & .307 & $(.714)$ & -.007 \\
\hline $\begin{array}{l}\text { I feel that new services should be made as } \\
\text { convenient as possible utilizing various devices, } \\
\text { such as cell phones, PDAs, etc. }\end{array}$ & -.047 & .174 & $(.590)$ & .375 \\
\hline $\begin{array}{l}\text { I am concerned about quality of the information and } \\
\text { services delivered. }\end{array}$ & .272 & .271 & .075 & $(.831)$ \\
\hline $\begin{array}{l}\text { I am concerned about reliable delivery of } \\
\text { information and services. }\end{array}$ & .371 & .190 & .180 & $(.742)$ \\
\hline I am concerned about accuracy of transaction. & .430 & .234 & .031 & (.708) \\
\hline I like to have new types of services. & .088 & .214 & .504 & .519 \\
\hline Cronbach's Alpha (selected items) & .919 & .873 & .734 & .895 \\
\hline
\end{tabular}

Extraction Method: Principal Component Analysis.

Rotation Method: Varimax with Kaiser Normalization.

a Rotation converged in 6 iterations.

Figure 9. Component loadings for rotation solution for means objectives. 
The means objectives scale for the final factor solution included 20 items. The ratio of sample size (198) to number of items (20) was 10:1, which was an acceptable size for factor analysis (Hair et al., 1998).

\section{Findings}

Exploratory factor analysis reported a 4-factor 20-item model (see Table 12) for the means objectives scale. Factor one (six items) represented public trust, factor two (seven items) represented information access, factor three (four items) represented public accessibility, and factor four (three items) represented quality of service.

Using this data set, the correlated item-total correlation and Cronbach's $\alpha$ for the same 4-factor model were calculated. The corrected item-total correlation was 0.466 to 0.625 for public trust, 0.503 to 0.606 for information access, 0.590 to 0.759 for public accessibility, and 0.623 to 0.638 for quality of service. Reliability statistics (Cronbach's $\alpha$ ) were $0.919,0.873,0.734$, and 0.895 for public trust, information access, public accessibility, and quality of service, respectively (see Figure 9 at the bottom of each component column). Overall reliability for the entire scales (20 items) was 0.901 . The hotelling's T-squared test was significant for all 4 subscales $(p<0.001)$, with F values being $3.599,17.724,14.723$, and 15.830 for public trust, information access, public accessibility, and quality of services, respectively. 
Table 12

Factor Pattern for Measures of Means Objectives

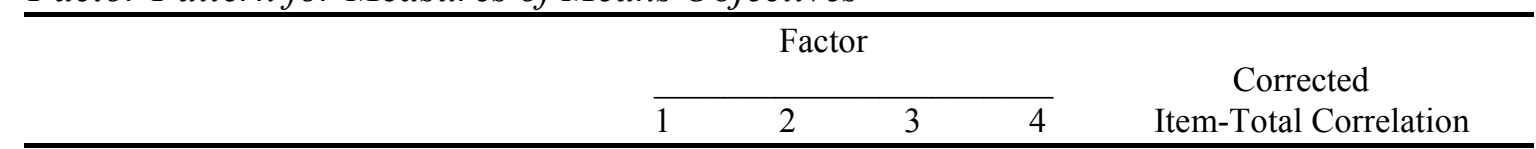

\section{Public trust}

I am concerned about identity theft. $\quad .897$

.525

I am concerned about the safeguarding $\quad .890$

.571

of personal information.

I am concerned about privacy risks.

.874

.562

I am concerned about misuse

.816

of my credit card.

I am concerned about transaction

.778

.625

security.

I am concerned about sharing

.687

of personal information.

\section{Information access}

I like to get as much information

about services as possible.

I like to have information on demand.

I like to have a great amount of

I like to have search criteria.

I like the opportunity for two-way

I like to minimize the risk of skipping

\section{Public accessibility}

I feel accessibility for individuals with 
culture, geographical location, etc.

Table 12 (continued)

\begin{tabular}{|c|c|c|c|c|c|}
\hline & & & & & \\
\hline & 1 & 2 & 3 & 4 & Item-Total Correlation \\
\hline I like to promote public outreach. & & & .714 & & .479 \\
\hline $\begin{array}{l}\text { I feel that new services should be } \\
\text { made as convenient as possible } \\
\text { utilizing various devices, such as } \\
\text { cell phones, PDAs, etc. }\end{array}$ & & & .590 & & .403 \\
\hline Quality of service & & & & & \\
\hline $\begin{array}{l}\text { I am concerned about quality of } \\
\text { the information and services delivered. }\end{array}$ & & & & .831 & .623 \\
\hline $\begin{array}{l}\text { I am concerned about reliable delivery } \\
\text { of information and services. }\end{array}$ & & & & .742 & .638 \\
\hline $\begin{array}{l}\text { I am concerned about accuracy of } \\
\text { transaction. }\end{array}$ & & & & .708 & .623 \\
\hline
\end{tabular}

\section{Data Analysis for Fundamental Objectives}

\section{Descriptive Statistics}

The output from the descriptive statistics (Table 13) from the total of 210

responses indicated that all 28 items were perceived to be relevant because the mean values for most items were greater than 4, reflecting the survey answers of "agree" and "strongly agree." Though two items had mean values of less than 4, as the values were close to 4 (3.56 and 3.95), they were not eliminated. The two most important items, with the highest mean of 4.47, were "It is important to find information and services easily" and "It is important that information and services are useful." The least significant item, 
with the lowest mean of 3.56, was "It is important to make using e-government a social event."

Table 13

Descriptive Statistics for Fundamental Objectives $(N=210)$

\begin{tabular}{|c|c|c|c|c|}
\hline Item & Min & Max & Mean & $\begin{array}{l}\text { Std. } \\
\text { Deviation }\end{array}$ \\
\hline It is important to optimize citizen satisfaction. & 1 & 5 & 4.24 & .706 \\
\hline It is important to always consider overall good of society. & 1 & 5 & 4.27 & .717 \\
\hline It is important to ensure time flexibility in using services. & 1 & 5 & 4.26 & .673 \\
\hline It is important to offer personal interaction. & 1 & 5 & 4.07 & .810 \\
\hline It is important to reduce effort in receiving service. & 1 & 5 & 4.11 & .774 \\
\hline It is important to minimize personal hassle. & 1 & 5 & 4.35 & .663 \\
\hline It is important to find information and services easily. & 2 & 5 & 4.47 & .588 \\
\hline It is important that information and services are useful. & 1 & 5 & 4.47 & .612 \\
\hline It is important to keep down the cost of services. & 1 & 5 & 4.32 & .683 \\
\hline It is important to minimize travel costs. & 2 & 5 & 4.24 & .678 \\
\hline It is important to make communication cost efficient. & 2 & 5 & 4.31 & .630 \\
\hline $\begin{array}{l}\text { It is important to minimize the time it takes to find } \\
\text { information and service. }\end{array}$ & 2 & 5 & 4.41 & .659 \\
\hline It is important to minimize processing time. & 1 & 5 & 4.35 & .705 \\
\hline It is important to minimize search time. & 1 & 5 & 4.38 & .690 \\
\hline It is important to minimize payment time. & 1 & 5 & 4.19 & .782 \\
\hline It is important to minimize overall communication time. & 1 & 5 & 4.26 & .745 \\
\hline $\begin{array}{l}\text { It is important to minimize the time it takes to find } \\
\text { information and services. }\end{array}$ & 1 & 5 & 4.23 & .724 \\
\hline $\begin{array}{l}\text { It is important to respond quickly to requests for } \\
\text { information and services. }\end{array}$ & 2 & 5 & 4.44 & .640 \\
\hline
\end{tabular}


It is important to ensure quick delivery of information and services.

Table 13 (continued)

\begin{tabular}{|c|c|c|c|c|}
\hline Item & Min & Max & Mean & $\begin{array}{l}\text { Std. } \\
\text { Deviation }\end{array}$ \\
\hline It is important to minimize dispatch time. & 1 & 5 & 4.14 & .715 \\
\hline $\begin{array}{l}\text { It is important to make using e-government a social } \\
\text { event. }\end{array}$ & 1 & 5 & 3.56 & .922 \\
\hline $\begin{array}{l}\text { It is important to bring government services closer to } \\
\text { citizens. }\end{array}$ & 2 & 5 & 4.22 & .663 \\
\hline $\begin{array}{l}\text { It is important to inspire citizens to use e-government } \\
\text { online services. }\end{array}$ & 1 & 5 & 3.95 & .781 \\
\hline $\begin{array}{l}\text { It is important to avoid giving citizens cause to regret } \\
\text { using e-government online services. }\end{array}$ & 2 & 5 & 4.26 & .713 \\
\hline $\begin{array}{l}\text { It is important to minimize unnecessary driving through } \\
\text { the advantages of having services accessible from } \\
\text { home (e.g., parking, accident, etc.). }\end{array}$ & 1 & 5 & 4.20 & .737 \\
\hline It is important to minimize pollution. & 1 & 5 & 4.43 & .697 \\
\hline It is important to minimize environmental impact. & 1 & 5 & 4.36 & .747 \\
\hline
\end{tabular}

\section{Item Purification and Reliability Test}

The item purification process resulted in retaining all 28 items for which all the correlation coefficients (see the "Corrected Item-Total Correlation" column in Table 14) were greater then 0.05 , considering high correlation. When high correlation occurs between measures of the same construct, constructs are considered valid (Straub, 1989). No items with extremely high correlation coefficients (greater than 0.90 ) were found because they could cause problems due to singularity. 
Table 14

Item-Total Statistics for Fundamental Objectives

\begin{tabular}{|c|c|c|c|}
\hline Item & $\begin{array}{c}\text { Scale } \\
\text { Mean if } \\
\text { Item } \\
\text { Deleted }\end{array}$ & $\begin{array}{c}\text { Scale } \\
\text { Variance if } \\
\text { Item } \\
\text { Deleted }\end{array}$ & $\begin{array}{l}\text { Corrected } \\
\text { Item-Total } \\
\text { Correlation }\end{array}$ \\
\hline It is important to optimize citizen satisfaction. & 114.79 & 183.525 & .601 \\
\hline $\begin{array}{l}\text { It is important to always consider overall good of } \\
\text { society. }\end{array}$ & 114.76 & 183.879 & .572 \\
\hline $\begin{array}{l}\text { It is important to ensure time flexibility in using } \\
\text { services. }\end{array}$ & 114.77 & 181.376 & .756 \\
\hline It is important to offer personal interaction. & 114.96 & 182.764 & .553 \\
\hline It is important to reduce effort in receiving service. & 114.91 & 182.194 & .609 \\
\hline It is important to minimize personal hassle. & 114.68 & 182.641 & .694 \\
\hline It is important to find information and services easily. & 114.56 & 184.113 & .693 \\
\hline It is important that information and services are useful. & 114.56 & 182.783 & .747 \\
\hline It is important to keep down the cost of services. & 114.71 & 182.485 & .681 \\
\hline It is important to minimize travel costs. & 114.79 & 181.870 & .721 \\
\hline It is important to make communication cost efficient. & 114.72 & 183.179 & .701 \\
\hline $\begin{array}{l}\text { It is important to minimize the time it takes to find } \\
\text { information and service. }\end{array}$ & 114.62 & 181.625 & .758 \\
\hline It is important to minimize processing time. & 114.68 & 179.942 & .797 \\
\hline It is important to minimize search time. & 114.65 & 180.765 & .770 \\
\hline It is important to minimize overall communication time. & 114.77 & 180.570 & .719 \\
\hline $\begin{array}{l}\text { It is important to minimize the time it takes to find } \\
\text { information and services. }\end{array}$ & 114.80 & 179.781 & .784 \\
\hline $\begin{array}{l}\text { It is important to respond quickly to requests for } \\
\text { information and services. }\end{array}$ & 114.59 & 183.085 & .694 \\
\hline
\end{tabular}


It is important to ensure quick delivery of information

114.60

182.710

and services.

$114.91 \quad 179.614 \quad .769$

It is important to minimize shipping time.

$114.89 \quad 180.605$

.749

Table 14 (continued)

\begin{tabular}{|c|c|c|c|}
\hline Item & $\begin{array}{l}\text { Scale } \\
\text { Mean if } \\
\text { Item } \\
\text { Deleted }\end{array}$ & $\begin{array}{l}\text { Scale } \\
\text { Variance if } \\
\text { Item } \\
\text { Deleted }\end{array}$ & $\begin{array}{l}\text { Corrected } \\
\text { Item-Total } \\
\text { Correlation }\end{array}$ \\
\hline $\begin{array}{l}\text { It is important to make using e-government a social } \\
\text { event. }\end{array}$ & 115.47 & 180.327 & .579 \\
\hline $\begin{array}{l}\text { It is important to bring government services closer to } \\
\text { citizens. }\end{array}$ & 114.81 & 183.686 & .634 \\
\hline $\begin{array}{l}\text { It is important to inspire citizens to use e-government } \\
\text { online services. }\end{array}$ & 115.08 & 181.142 & .655 \\
\hline $\begin{array}{l}\text { It is important to avoid giving citizens cause to regret } \\
\text { using e-government online services. }\end{array}$ & 114.77 & 182.570 & .646 \\
\hline $\begin{array}{l}\text { It is important to minimize unnecessary driving } \\
\text { through the advantages of having services accessible } \\
\text { from home (e.g., parking, accident, etc.). }\end{array}$ & 114.83 & 182.057 & 649 \\
\hline It is important to minimize pollution. & 114.60 & 185.467 & .504 \\
\hline It is important to minimize environmental impact. & 114.67 & 184.175 & .532 \\
\hline
\end{tabular}

\section{Dimensionality}

To address the dimensionality of the remaining constructs, the Kaiser-MeyerOlkin (KMO) measure of sampling adequacy was used. The KMO measure of 0.929 (see Figure 10) was large enough to proceed with factor analysis. as the extracted factors would account for a substantial amount of variance. Therefore, the factor solution generated was reliable. 
The observed significance level for Bartlett's test of sphericity was 0.000 (see Figure 10) indicating that the relationship among variables was strong. Thus, factor analysis was appropriate.

\begin{tabular}{|c|c|c|}
\hline \multicolumn{2}{|c|}{$\begin{array}{l}\text { Kaiser-Meyer-Olkin Measure of Sampling } \\
\text { Adequacy. }\end{array}$} & .929 \\
\hline \multirow{3}{*}{$\begin{array}{l}\text { Bartlett's Test of } \\
\text { Sphericity }\end{array}$} & Approx. Chi-Square & 4934.958 \\
\hline & & 378 \\
\hline & Sig. & .000 \\
\hline
\end{tabular}

Figure 10. KMO and Bartlett's test for fundamental objectives.

\section{Factor Analysis (Principal Component Analysis)}

The exploratory factor analysis using principal component analysis (PCA) identified outliers and extracted four components (factors) while reducing the number of variables. Initially, the communality values were evaluated in order to select the items that account for at least half of the variance in the variables by the extracted factors. The first iteration of the PCA computing without specifying the number of factors resulted in removing two items for which the communality values were less then 0.5 , reflecting that each one accounted for less than $50 \%$ of the variance in the variables. The removed items were "It is important to offer personal interaction" and "It is important to reduce effort in receiving services." The second iteration resulted in no further deletion of items. The table of communalities from the second iteration (Table 15) showed the remaining 26 items that were used to examine the pattern of factor loadings. Table 15 indicated that the items with the least (52.0\%) and the most (88.2\%) accounted for were "It is important 
to minimize unnecessary driving...." and "It is important to minimize environmental impact," respectively.

\section{Table 15}

Communalities for Fundamental Objectives

\begin{tabular}{llll}
\hline \multicolumn{1}{c}{ Item } & Initial & Extraction \\
\hline It is important to optimize citizen satisfaction. & 1.000 & .527 \\
It is important to always consider overall good of society. & 1.000 & .606 \\
It is important to ensure time flexibility in using services. & 1.000 & .601 \\
It is important to minimize personal hassle. & 1.000 & .558 \\
It is important to find information and services easily. & 1.000 & .799 \\
It is important that information and services are useful. & 1.000 & .806 \\
It is important to keep down the cost of services. & 1.000 & .729 \\
It is important to minimize travel costs. & 1.000 & .773 \\
It is important to make communication cost efficient. & 1.000 & .712 \\
It is important to minimize the time it takes to find information & 1.000 & .750 \\
and service. & & 1.000 & .758 \\
It is important to minimize processing time. & 1.000 & .773 \\
It is important to minimize search time. & 1.000 & .812 \\
It is important to minimize payment time. & & & \\
It is important to ensure quick delivery of information and \\
services.
\end{tabular}


It is important to minimize shipping time.

It is important to minimize dispatch time.

It is important to make using e-government a social event.
$1.000 \quad .745$

$1.000 \quad .748$

$1.000 \quad .745$

Table 15 (continued)

\begin{tabular}{|c|c|c|}
\hline Item & Initial & Extraction \\
\hline It is important to bring government services closer to citizens. & 1.000 & .637 \\
\hline $\begin{array}{l}\text { It is important to inspire citizens to use e-government online } \\
\text { services. }\end{array}$ & 1.000 & .710 \\
\hline $\begin{array}{l}\text { It is important to avoid giving citizens cause to regret using e- } \\
\text { government online services. }\end{array}$ & 1.000 & .576 \\
\hline $\begin{array}{l}\text { It is important to minimize unnecessary driving through the } \\
\text { advantages of having services accessible from home (e.g., } \\
\text { parking, accident, etc.). }\end{array}$ & 1.000 & .520 \\
\hline It is important to minimize pollution. & 1.000 & .875 \\
\hline It is important to minimize environmental impact. & 1.000 & .882 \\
\hline
\end{tabular}

To detect outliers, the regression equation was used to calculate the factor scores where the cases with factor scores either greater than 3.0 or smaller than -3.0 were identified. Excluding eight outliers, the remaining 202 cases were used to extract components.

To extract the principal components, the Varimax rotation with Kaiser normalization method was used. The first iteration without specifying the number of factors detected one item for which the communality was 0.436 , representing less than $50 \%$ of the variance in the variables; thus, it was removed. The removed item was "It is important to optimize citizen satisfaction." 
The second iteration represented all 25 items with the communality value greater than 0.5 and presented a 4-componet (factor) solution (see Figure 11) that was not difficult to interpret. These four components explained more than $60 \%$ of the cumulative variance (see Figure 11), which was ideal for factor analysis. The four components accounted for $67.298 \%$ of the total variances where the first factor accounted for $50.058 \%$, the second $7.161 \%$, the third $5.686 \%$, and the fourth $4,393 \%$. The remaining factors were not considered significant. The scree plot (see Figure 12) also supported the 4-factor model in that the curve began to flatten after the $4^{\text {th }}$ component.

\begin{tabular}{|c|c|c|c|c|c|c|c|c|c|}
\hline \multirow[b]{2}{*}{ Component } & \multicolumn{3}{|c|}{ Initial Eigenvalues } & \multicolumn{3}{|c|}{$\begin{array}{c}\text { Extraction Sums of Squared } \\
\text { Loadings }\end{array}$} & \multicolumn{3}{|c|}{$\begin{array}{c}\text { Rotation Sums of Squared } \\
\text { Loading }\end{array}$} \\
\hline & Total & $\begin{array}{c}\% \text { of } \\
\text { Variance }\end{array}$ & $\begin{array}{c}\text { Cumulative } \\
\%\end{array}$ & Total & $\begin{array}{c}\% \text { of } \\
\text { Variance }\end{array}$ & $\begin{array}{c}\text { Cumulative } \\
\%\end{array}$ & Total & $\begin{array}{c}\% \text { of } \\
\text { Variance }\end{array}$ & $\begin{array}{c}\text { Cumulative } \\
\%\end{array}$ \\
\hline 1 & 12.515 & 50.058 & 50.058 & 12.515 & 50.058 & 50.058 & 5.609 & 22.436 & 22.436 \\
\hline 2 & 1.790 & 7.161 & 57.220 & 1.790 & 7.161 & 57.220 & 4.570 & 18.278 & 40.714 \\
\hline 3 & 1.421 & 5.686 & 62.906 & 1.421 & 5.686 & 62.906 & 3.618 & 14.473 & 55.186 \\
\hline 4 & 1.098 & 4.393 & 67.298 & 1.098 & 4.393 & 67.298 & 3.028 & 12.112 & 67.298 \\
\hline 5 & .964 & 3.855 & 71.153 & & & & & & \\
\hline 6 & .850 & 3.402 & 74.555 & & & & & & \\
\hline 7 & .642 & 2.567 & 77.122 & & & & & & \\
\hline 8 & .633 & 2.532 & 79.654 & & & & & & \\
\hline 9 & .590 & 2.360 & 82.014 & & & & & & \\
\hline 10 & .542 & 2.167 & 84.180 & & & & & & \\
\hline 11 & .490 & 1.961 & 86.141 & & & & & & \\
\hline 12 & .452 & 1.809 & 87.950 & & & & & & \\
\hline 13 & .420 & 1.679 & 89.630 & & & & & & \\
\hline 14 & .406 & 1.625 & 91.254 & & & & & & \\
\hline 15 & .386 & 1.542 & 92.796 & & & & & & \\
\hline 16 & .325 & 1.301 & 94.097 & & & & & & \\
\hline 17 & .280 & 1.120 & 95.218 & & & & & & \\
\hline 18 & .222 & .887 & 96.104 & & & & & & \\
\hline 19 & .210 & .839 & 96.944 & & & & & & \\
\hline 20 & .176 & .705 & 97.649 & & & & & & \\
\hline 21 & .164 & .654 & 98.303 & & & & & & \\
\hline 22 & .134 & .535 & 98.839 & & & & & & \\
\hline 23 & .115 & .461 & 99.300 & & & & & & \\
\hline 24 & .102 & .408 & 99.708 & & & & & & \\
\hline 25 & .073 & .292 & 100.000 & & & & & & \\
\hline
\end{tabular}

Extraction Method: Principal Component Analysis. 
Figure 11. Total variance explained for fundamental objectives.

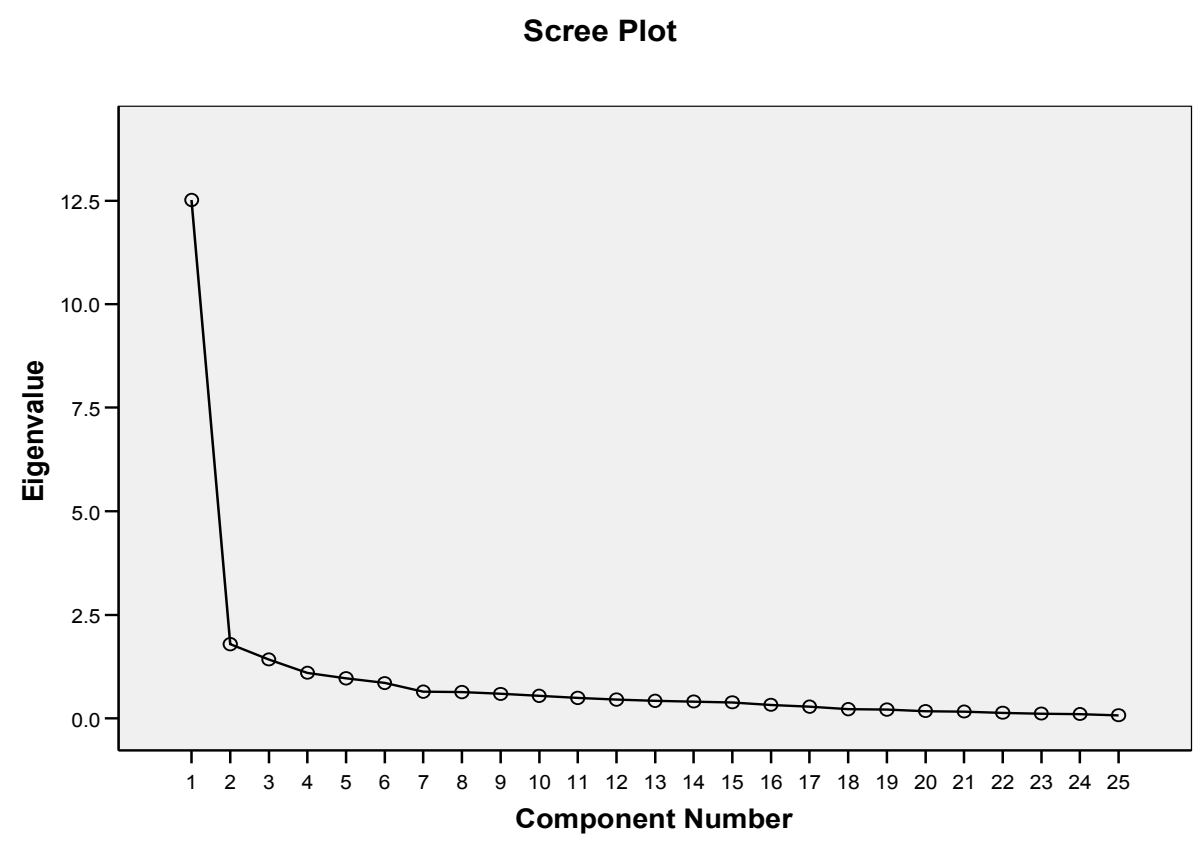

Figure 12. Scree plot for fundamental objectives.

To discuss the unrotated factor solution, the unrotated 4-factor model was inadequate to interpret, as it did not provide a meaningful pattern of the variable loadings. The unrotated solution indicated that the first factor was a general factor for which most variables were loaded highly while the subsequent factors were based on the residual amount of variance (Hair et al., 1998) for which the relatively small number of variables were loaded. Factor rotation achieved a more meaningful pattern of the variable loadings by redistributing the variance that helped interpreting factors. The component plot in rotated space (see Figure 13) reflected that the relative importance of the factors was equalized and that the factor loadings were plotted in the high end of the axes. 


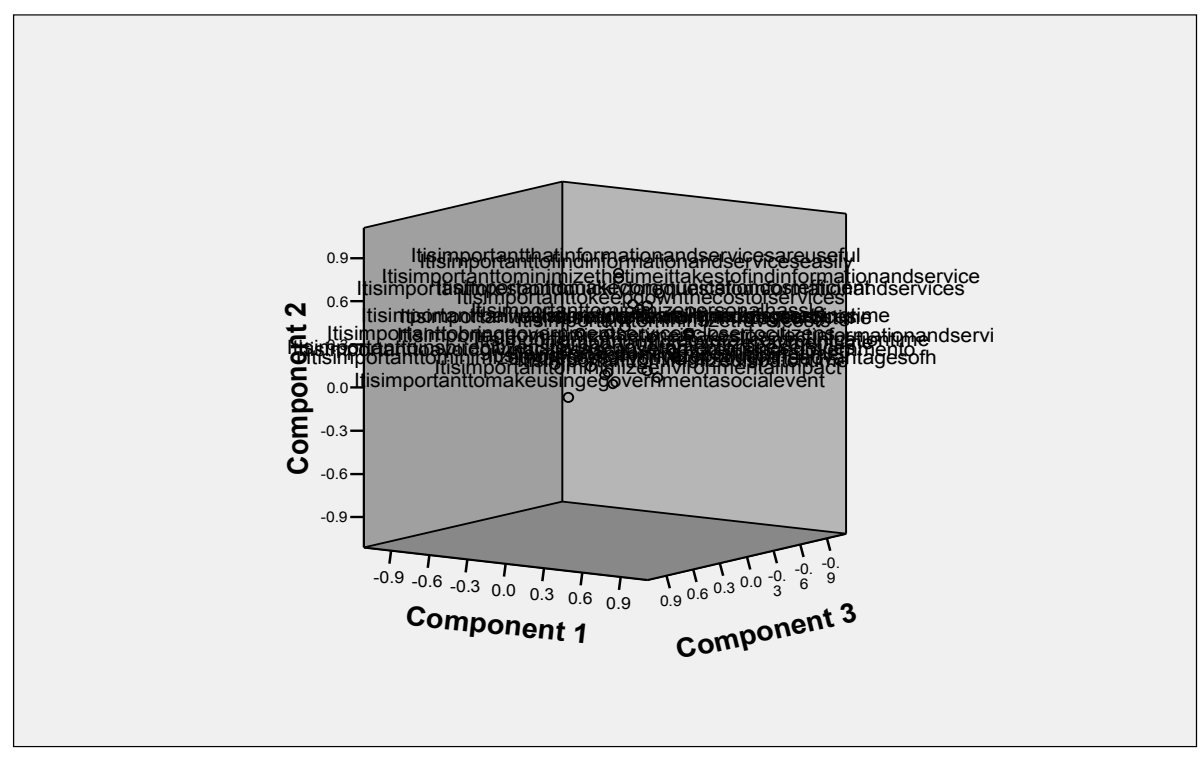

Figure 13. Component plot in rotated space for fundamental objectives.

The rotated component matrix (see Figure 14) showed the four components with associated variables sorted by size of the factor loadings. The factor loadings of selected items were in parenthesis. The higher the factor loadings, the more it contributed to the variable and the stronger the variable correlated with the factor. Seven items were excluded from the 4-factor solution because three items showed low loadings (less than 0.5 ) and four items showed high loadings (greater than 0.5 ) on multiple factors reflecting that they were not factorially pure.

The first group of variables was loaded from 0.630 to 0.756 , the second group from 0.585 to 0.804 , the third from 0.511 to 0.792 , and the fourth from 0.541 to 0.866 . The 4-factor model was not difficult to interpret, corresponding with time savings (seven 
items), efficiency of service (three items), service to citizen (five items), and social

awareness (three items).

\begin{tabular}{|c|c|c|c|c|}
\hline & \multicolumn{4}{|c|}{ Component } \\
\hline & 1 & 2 & 3 & 4 \\
\hline It is important to minimize payment time. & $(.756)$ & .254 & .238 & .162 \\
\hline It is important to minimize search time. & $(.750)$ & .414 & .126 & .194 \\
\hline It is important to minimize overall communication time. & $(.745)$ & .280 & .277 & .071 \\
\hline It is important to minimize processing time. & $(.734)$ & .422 & .106 & .229 \\
\hline $\begin{array}{l}\text { It is important to minimize the time it takes to select } \\
\text { information and services. }\end{array}$ & $(.727)$ & .306 & .272 & .148 \\
\hline It is important to minimize dispatch time. & $(.677)$ & .144 & .376 & .267 \\
\hline It is important to minimize shipping time. & $(.630)$ & .194 & .427 & .214 \\
\hline It is important to minimize travel costs. & .477 & .370 & .158 & .436 \\
\hline It is important that information and services are useful. & 254 & $(.804)$ & .210 & .176 \\
\hline It is important to find information and services easily. & .295 & $(.778)$ & .268 & .115 \\
\hline $\begin{array}{l}\text { It is important to minimize the time it takes to find } \\
\text { information and service. }\end{array}$ & .509 & .674 & .119 & .157 \\
\hline $\begin{array}{l}\text { It is important to respond quickly to requests for } \\
\text { information and services. }\end{array}$ & .507 & .608 & .251 & -.002 \\
\hline $\begin{array}{l}\text { It is important to ensure quick delivery of information and } \\
\text { services. }\end{array}$ & .509 & .597 & .337 & .018 \\
\hline It is important to make communication cost efficient. & .320 & $(.585)$ & .146 & .433 \\
\hline It is important to keep down the cost of services. & .291 & .499 & .068 & .489 \\
\hline It is important to minimize personal hassle. & .402 & .463 & .349 & .245 \\
\hline It is important to ensure time flexibility in using services. & .316 & .415 & .400 & .292 \\
\hline It is important to make using egovernment a social event. & .267 & .026 & $(.792)$ & .130 \\
\hline $\begin{array}{l}\text { It is important to inspire citizens to use egovernment } \\
\text { online services. }\end{array}$ & .152 & .241 & $(.778)$ & .117 \\
\hline $\begin{array}{l}\text { It is important to bring government services closer to } \\
\text { citizens. }\end{array}$ & .158 & .320 & $(.669)$ & .175 \\
\hline $\begin{array}{l}\text { It is important to avoid giving citizens cause to regret } \\
\text { using egovernment online services }\end{array}$ & .285 & .208 & $(.565)$ & .349 \\
\hline $\begin{array}{l}\text { It is important to minimize unnecessary driving through } \\
\text { the advantages of having services accessible from home } \\
\text { (e.g., parking, accident, etc.). }\end{array}$ & .358 & .150 & $(.511)$ & .200 \\
\hline It is important to minimize pollution. & .150 & .098 & .180 & $(.866)$ \\
\hline It is important to minimize environmental impact. & .207 & .028 & .208 & $(.818)$ \\
\hline It is important to always consider overall good of society. & .011 & .376 & .293 & $(.541)$ \\
\hline Cronbach's Alpha (selected items) & 931 & .846 & .830 & .799 \\
\hline
\end{tabular}

Extraction Method: Principal Component Analysis.

Rotation Method: Varimax with Kaiser Normalization.

a Rotation converged in 7 iterations.

Figure 14. Component loading for rotation solution for fundamental objectives. 
The fundamental objectives scale for the final factor solution included 18 items. The ratio of sample size (202) to number of items (18) was 11:1, which was an acceptable size for factor analysis (Hair et al., 1998).

\section{Findings}

Exploratory factor analysis reported a 4-factor 18-item model (see Table 16) for the fundamental objectives scale; factor one (seven items) was related to time savings, factor two (three items) was related to efficiency of service, factor three (five items) was related to service to citizen, and factor four (three items) was related to social awareness.

Using this data set, the correlated item-total correlation and Cronbach's $\alpha$ for the same 4-factor model were calculated. The corrected item-total correlation was 0.727 to 0.822 for time savings, 0.616 to 0.765 for efficiency of service, 0.565 to 0.709 for service to citizen, and 0.487 to 0.701 for social awareness. Reliability statistics (Cronbach's $\alpha$ ) were $0.931,0.846,0.830$, and 0.799 for time saving, efficiency of service, service to citizen, and social awareness, respectively (see Figure 14 at the bottom of each component column). Overall reliability for the entire scales (18 items) was 0.936 . The hotelling's T-squared test was significant for all 4 subscales $(p<0.001)$, with $\mathrm{F}$ values being $7.504,9.039,40.842$, and 8.460 for time savings, efficiency of service, service to citizen, and social awareness, respectively. 
Table 16

Factor Pattern for Measures of Fundamental Objectives

Factor

Corrected

\begin{tabular}{llll}
\hline 1 & 2 & 3 & 4
\end{tabular} Item-Total Correlation

\section{Time savings}

$\begin{array}{lll}\text { It is important to minimize payment time. } & .756 & .724\end{array}$

$\begin{array}{lll}\text { It is important to minimize search time. } & .750 & .752\end{array}$

$\begin{array}{lll}\text { It is important to minimize overall } & .745 & .712\end{array}$

communication time.

$.734 \quad .751$

time.

.727

.752

takes to select information and services.

It is important to minimize dispatch time. $\quad .677$

It is important to minimize shipping time. $\quad .630$

\section{Efficiency of service}

It is important that information and

services are useful.

\section{Service to citizen}

It is important to make using 
driving through the advantages of having services accessible from home

(e.g., parking, accident, etc.).

Table 16 (continued)

\begin{tabular}{|c|c|c|c|c|c|}
\hline & \multicolumn{4}{|c|}{ Factor } & \multirow{2}{*}{$\begin{array}{c}\text { Corrected } \\
\text { Item-Total Correlation }\end{array}$} \\
\hline & 1 & 2 & 3 & 4 & \\
\hline \multicolumn{6}{|l|}{ Social awareness } \\
\hline It is important to minimize pollution. & & & & .866 & .539 \\
\hline $\begin{array}{l}\text { It is important to minimize } \\
\text { environmental impact. }\end{array}$ & & & & .818 & .534 \\
\hline $\begin{array}{l}\text { It is important to always consider } \\
\text { overall good of society. }\end{array}$ & & & & .541 & .498 \\
\hline
\end{tabular}

\section{Relating the Means and Ends Factors}

In the means-ends relationship, as the means is the activity to achieve the ends, the means and ends (fundamental) objectives are related. Thus, the constructs of means and fundamental objectives must be related (Torkzadeh \& Dhillon, 2002). To address the relation, the cross-correlations among factors were examined. Table 17 provides the correlations for constructs in each objective and between objectives.

Subscales of means objectives (4 factors including public trust, information access, public accessibility and quality of service) are correlated more closely with the overall 20 -item means objectives than with subscales of fundamental objectives, indicated by the ranges of 0.777 to 0.792 for means objectives that are greater than the ranges of 0.551 to 0.652 for fundamental objectives. Likewise, subscales of fundamental objectives (4 factors including time savings, efficiency of service, services to citizen, and 
social awareness) are correlated more closely with the overall 18-item fundamental objectives than with subscales of means objectives, indicated by the ranges of 0.688 to 0.926 that are greater than the ranges of 0.460 to 0.638 . All subscales of means objectives correlate strongly with each other (ranged from 0.313 to 0.675 ) while all subscales of fundamental objectives also correlate strongly with each other (ranged from 0.490 to 0.718$)$.

Table 17

Correlations Among Constructs $(n=210)$

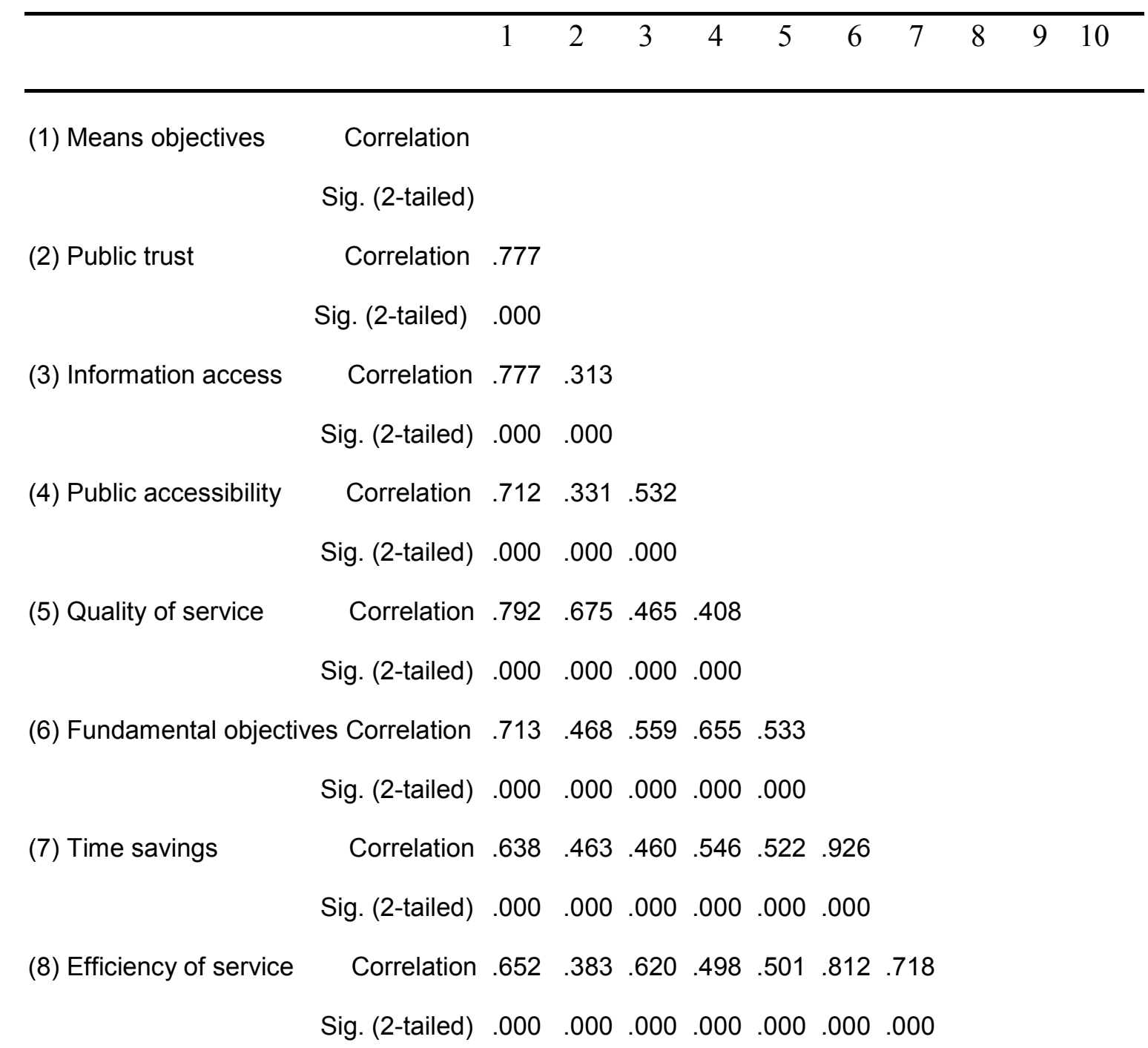


Table 17 (continued)

$\begin{array}{llllllllll}1 & 2 & 3 & 4 & 5 & 6 & 7 & 8 & 9 & 10\end{array}$

(9) Service to citizen

Correlation $.575 .332 .485 .602 .364 \quad 870.705 .618$

$\begin{array}{lllllllllllll}\text { Sig. (2-tailed) } & .000 & .000 & .000 & .000 & .000 & .000 & .000 & .000\end{array}$

(10) Social awareness

$\begin{array}{llllllllll}\text { Correlation } & .551 & .373 & .381 & .570 & .406 & .688 & .496 & .490 & .515\end{array}$

$\begin{array}{lllllllllll}\text { Sig. (2-tailed) } & .000 & .000 & .000 & .000 & .000 & .000 & .000 & .000 & .000\end{array}$

\section{Summary of Results}

The use of descriptive statistics analysis revealed the most and least important items that influence citizens to use e-government services. For the means objectives, the most important items were "I like to discourage hacking," "I am concerned about identity theft," and "I am concerned about the safeguarding of personal information." The least important item was "I like to have a variety of foreign language options available to people." For the fundamental objectives, the most important items were "It is important to find information and services easily" and "It is important that information and services are useful." The least important item was "It is important to make using e-government a social event." Overall, respondents felt strongly about protecting online security, saving time, and minimizing environmental impact, while being less concerned about styling and formatting in Web site design, providing foreign languages, and making egovernment a social event. 
The results provided evidence of construct validity and reliability for the means and fundamental objectives. The construct validity was provided by the item purification process where the correlation coefficients reflected high correlation. The reliability was evidenced by the high Cronbach's Alpha that implied the internal consistency of the scale variables.

Using the PCA procedure, the 46 variables were reduced to 20 and 210 cases were reduced to 198 for the means objectives while the 24 variables were reduced to 18 and 210 cases were reduced to 202 for the fundamental objectives. Then, two factor models were presented for each type of objective variable. Each factor model accounted for $64.738 \%$ and $67.298 \%$ of covariance among variables for the means and fundamental objectives, respectively. One model measures the means objectives in terms of public trust, information access, public accessibility, and quality of services. The other measures the fundamental objectives in terms of time savings, efficiency of service, service to citizen, and social awareness. The two sets of factor models developed in this paper together measure the factors that influence the success of e-government initiatives. 


\section{Chapter 5 \\ Conclusions, Implications, Recommendations, and Summary}

\section{Conclusions}

The research conceptualized the value of e-government and developed instruments to measure factors that influence the success of e-government initiatives. This was an applied research study into ideas suggested by Keeney (1999) that attempted to develop a sample of customer values for a specific category of products where the customer was the citizen (e-government services users) and the category was egovernment service. The customer values for e-government services ranged from benefits and costs of services (e.g., reduced effort) to possible benefits and costs to the world (e.g., environmental impact). The citizen's values for e-government services were generated from the 125 items (see Appendix A) developed from the exploratory study of Internet commerce by Torkzadeh and Dhillon (2002) and from the research pool published in the leading refereed publications during the 6-year period from 2000 to 2005 (see Appendix E).

The theoretical foundation for this research came from two concepts in Decision Analysis. One of the concepts is means-ends analysis. Means-ends analysis is a problem-solving strategy that attempts to search for and apply an action (means) to achieve a goal (ends). The means is the activity to achieve the ends. A second concept is the notion of value, as posited by Keeney (1992) in value-focused thinking. The valuefocused approach stresses that values are fundamentally important in any decision situation, while alternatives are relevant only because they are a means to achieve the 
desired values. Thus, the thinking should focus first on values, and later on alternatives that might achieve them. Value-focused thinking, therefore, asks the most important question: what do people really value in a given situation? (Keeney, 1992). The two concepts of means-ends chain and value-focused thinking are closely related.

For the empirical study, the list of values (objectives) were classified into means and ends types of objectives depending on the characteristics of attributes. The means objectives help to achieve what is important to the e-government users - fundamental objectives. Data collection and analysis were conducted against these two types independently. Using a sample of 210 responses from e-government service users, two sets of instruments were created that measure the factors that influence the success of egovernment initiatives. One instrument (4-factor 20-item model) measures the means objectives in terms of public trust, information access, public accessibility, and quality of services. The other instrument (4-factor 18-item model) measures the fundamental objectives in terms of time savings, efficiency of service, service to citizen, and social awareness. Evidence of content validity and construct validity and reliability was presented.

The measuring of research constructs is neither simple nor straightforward (Straub, 1989). Due to the inherent nature of user surveys, any study would have a certain amount of bias. Since e-government encompasses many types of services for users with different abilities, a study of this kind faces various issues in assessing values. One person may have found online e-government services convenient and easy to use, while another may have found them difficult and impersonal. Thus, the net value of using the services could differ by individual. Although the research addressed the e-government services at some 
level of specificity, it mainly focused on general issues instead of a variety of servicespecific issues, in order to minimize any possible bias.

\section{Implications}

The success of e-government is contingent upon citizens' willingness to use egovernment services (Carter \& Belanger, 2005; Devadoss, Pan, \& Huang, 2002). As values are the basic principles that guide actions and preferences (Keeney, 1992), citizens are likely to use such services if they feel that they get better value than from conventional government services. As the value of Internet commerce to the customer is an important construct for academics and practitioners alike (Torkzadeh \& Dhillion, 2002), so is the value of e-government services to the citizens. This concept can also be used as a dependent or independent variable with preceding and ensuing constructs for egovernment research. The multi-dimensional measures discovered by this study can provide insight for the decision context of whether citizens should use e-government services and can help people understand the phenomena of e-government, the impact of this new technology, and its management.

The literature review undertaken in the course of this research found that most of the existing e-government studies are not empirical but rhetorical in nature (Norrise \& Moon, 2005; Devadoss et al., 2002). Hence, this empirical research contributes to the body of e-government research in the following ways: 
1. The study generated a list of e-government values that citizens consider most important when they engage with e-government services.

2. The study developed two instruments that can be used to measure the factors that influence the success of overall e-government initiatives.

3. The study demonstrated an instrument development process with reliability and validity.

4. The study combined analytic and empirical components to connect theory to social phenomena (Rummel, 1970). Factor analysis helped to connect the value theory to egovernment phenomena.

\section{Recommendations}

In the postindustrial setting, scholars contend that the implications for information technology lie in the nature of work, productivity, and economic growth (Torkzadeh \& Dhillon, 2002). IS could potentially create new ideas, increase values, and more effectively satisfy customer needs. The instrument developed in this research can be used as a tool to assess this potential. Because increasing value to citizens is the key ingredient in the success of e-government, this research provided a useful list of the comprehensive values for developing and improving the e-government initiatives. To apply the results, the objectives identified by the instruments can not only be put to use at a high level, such as developing strategic plans, but also directly be implemented or tailored to the specific services. In addition, the list of e-government values generated in this research can be used as a foundation for developing a quantitative model of egovernment value. 
As new services and features continue to be added to e-government initiatives, triggered by emerging technology and ever-increasing demand, governments continue their e-government march. Continued studies are needed to examine the progress and effectiveness of e-governments in delivering services and facilitating citizens' political participation (Moon, 2002). The scale developed in this study might need to be changed over time. For the means objectives, the public trust factor needs to address new risks arising from the use of emerging technology; the information access factor needs to explore the evolution of information retrieval techniques and requirements; the public accessibility factor needs to consider the impact of using new devices (e.g., wireless); and the quality of service factor should adopt for an increased level of service. For the fundamental objectives, factors such as time savings and social awareness remain relatively the same, as they are less directly affected by the changes than the means objectives. For both objectives, the instruments developed in this study will need to be refined to satisfy future research requirements.

\section{Summary}

IS is being applied vigorously by government units at national, regional, and local levels around the world (Marchionini, Samet, \& Brandt, 2003). In the 1990s, the advent of network-based IS represented a turning point in the strategic direction for government agencies, which now have the immense opportunity to utilize e-commerce to achieve their objectives (Kalakota \& Whinston, 1997) through e-government. Egovernment is narrowly defined as "the delivery of government information and services online through the Internet or other digital means" (West, 2004, p. 2). E-government can 
be viewed as (a) a transformation of the business of governance, i.e. improving service, and renewing administrative processes, and (b) a transformation of governance itself, i.e. re-examining the functioning of democratic practices and processes (Aichholzer \& Schmitzer, 2000).

Governments are employing network-based IS in the expectation that it will be cheaper, faster, and more convenient than traditional means of delivering products and services (McNeal, Tolbert, Mossberger, \& Dotterweich, 2003). Having invested an enormous amount of resources in e-government (Peters, Jansen, \& Engers, 2004), governments strive to succeed in this endeavor. To further the success of e-government, it is critical to understand and influence citizens' acceptance of e-government services (Fu, Farn, \& Chao, 2006) because the success of e-government initiatives is contingent upon citizens' willingness to use these services (Carter \& Belanger, 2005; Devadoss, Pan, \& Huang, 2002). However, it is not clear whether citizens will embrace the use of such services (Carter \& Belanger, 2004). As values are the basic principles that guide actions and preferences (Keeney, 1992), citizens are likely to use such services if they feel that they get better value than from conventional government services. Thus, e-government value to citizens is an important factor for the success of e-government. The two main goals of this research were:

1. To conceptualize the value of e-government.

2. To develop two instruments to measure factors that influence the success of egovernment initiatives - ends objectives and means objectives. 
The theoretical foundation for this research came from two concepts from Decision Analysis. Decision Analysis (Winterfeldt \& Edwards, 1986) is a field in business which seeks to improve human decision making by developing new concepts, theories, and tools. One of the concepts of Decision Analysis is means-ends analysis. Means-ends analysis is a problem solving strategy that attempts to search for and apply an action (means) to achieve a goal (ends). The means is the activity to achieve the ends. Thus, the means and ends objectives are related. A second concept is the notion of value, as discussed by Keeney in value-focused thinking (1992). The value-focused approach stresses that values are fundamentally important in any decision situation, while alternatives are relevant only because they are a means to achieve the desired values. Thus, the thinking should focus first on values and later on alternatives that might achieve them. The two concepts of the means-ends chain and value-focused thinking are closely related.

To develop a basis for formulating a model of e-government value for empirical study, a list of e-government objectives from the exploratory study by Torkzadeh and Dhillon (2002) and the published research pool during the 6-year period from 2000 to 2005 was generated. The e-government objectives then were grouped into two categories, means and ends (fundamental) objectives. Data collection and analysis were conducted against these two types independently. Using a sample of 210 responses from egovernment service users, two sets of instruments were developed that together measure the factors that influence the success of e-government initiatives. One instrument (4factor 20-item model) measures the means objectives in terms of public trust, information access, public accessibility, and quality of services (see Table 18). The other instrument 
(4-factor 18- item model) measures the fundamental objectives in terms of time savings, efficiency of service, service to citizen, and social awareness (see Table 19). Evidence of content validity and construct validity and reliability was presented.

Table 18

Measures of Means Objectives

Factor Item

Public trust

Information access

Public accessibility
I am concerned about identity theft.

I am concerned about the safeguarding of personal information.

I am concerned about privacy risks.

I am concerned about misuse of my credit card.

I am concerned about transaction security.

I am concerned about sharing of personal information.

I like to get as much information about services as possible.

I like to have information on demand.

I like to have a great amount of information.

I like to have search criteria.

I like the opportunity for two-way interaction.

I like to minimize the risk of skipping or missing information.

I like to have up-to-date information.

I feel accessibility for individuals with special needs (e.g., disabilities) should be maximized.

I like to minimize the digital divide demarcated by wealth, age, language, culture, geographical location, etc.

I like to promote public outreach.

I feel that new services should be made as convenient as 
Table 18 (continued)

Factor Item

possible utilizing various devices, such as cell phones, PDAs,

etc.

Quality of service

I am concerned about quality of the information and services

delivered.

I am concerned about reliable delivery of information and

services.

I am concerned about accuracy of transaction.

\section{Table 19}

Measures of Fundamental Objectives

Factor Item

\section{Time savings}

It is important to minimize search time.
It is important to minimize overall communication time.
It is important to minimize processing time.
It is important to minimize the time it takes to select information
and services.
It is important to minimize dispatch time.
It is important to minimize shipping time.
It is important that information and services are useful.
It is important to find information and services easily.

It is important to minimize payment time.

formation and services easily. 
Table 19 (continued)

Factor Item

It is important to make communication cost efficient.

Service to citizen

Social awareness
It is important to make using e-government a social event.

It is important to inspire citizens to use e-government online services.

It is important to bring government services closer to citizens. It is important to avoid giving citizens cause to regret using egovernment online services.

It is important to minimize unnecessary driving through the advantages of having services accessible from home (e.g., parking, accident, etc.).

It is important to minimize pollution.

It is important to minimize environmental impact.

It is important to always consider overall good of society.

The focus of science is theory. Data are meaningless in themselves until they are linked through propositions that confer meaning (Rummel, 1970). A scientific theory consists of analytic and empirical components. The analytic component reflects the linkage of reasoning that follows logical rules without empirical content, whereas the empirical component reflects the linking of empirical data for a theory to apply to reality (Rummel, 1970). The empirical component connects the analytic component to the facts. 
For this research, factor analysis helps to combine the analytic and empirical components in order to connect theory (value theory) to social phenomena (e-government phenomena).

As new services and features continue to be added to e-government initiatives, triggered by emerging technology and ever-increasing demand, governments continue their e-government march. Continued studies are needed to examine the progress and effectiveness of governments in delivering Web-based public services and facilitating citizens' Web-based political participation (Moon, 2002).

In the postindustrial setting, scholars contend that the implications for information technology lie in the nature of work, productivity, and economic growth (Torkzadeh \& Dhillon, 2002). IS could potentially create new ideas, increase values, and more effectively satisfy customer needs. The instrument developed in this research can be used as a tool to assess this potential. Because increasing value to citizens is the key ingredient in the success of e-government, this research provided a useful list of the comprehensive values for developing and improving the e-government initiatives. To apply the results, the objectives identified by the instruments can not only be put to use at a high level, such as developing strategic plans, but also directly be implemented or tailored to the specific services. In addition, the list of e-government values generated in this research provides a foundation for developing a quantitative model of e-government value. 


\title{
Appendix A
}

\section{Measures of Factors That Influence Internet Commerce Success (125 items by Torkzadeh \& Dhillon, 2002)}

\author{
Means Objectives \\ I am concerned about e-government legitimacy. \\ I am concerned about how much I can trust the vendor. \\ I am concerned about security for Internet commerce.. \\ I am concerned about seller legitimacy. \\ I am concerned about how much I can trust the vendor. \\ I am concerned about unauthorized access to my personal information. \\ I am concerned about hackers. \\ I like greater accessibility to product and service information. \\ I feel there is sufficient transaction protection for Internet commerce. \\ I feel that Internet transactions are speedy. \\ I feel that there is sufficient security built into the Internet. \\ I like more information about promotions. \\ I am satisfied with transaction speed. \\ I feel that safety of credit card use should be increased. \\ I like to able to feel the product. \\ I like to able to see the product. \\ I like to able to test the product. \\ I like to able to try the product. \\ I like to able to feel the product. \\ I like to get as much information about products as possible. \\ I am worried about abuse of personal information. \\ I feel Internet commerce transaction is fast. \\ I feel the accuracy of product information is important. \\ I am concerned when I use my credit card. \\ I like assurance of delivery of purchased product. \\ I am concerned about misuse of my credit card. \\ I am worried about who will have access to my credit card number. \\ I like as accurate product information as possible. \\ I am concerned about unauthorized use of my credit card. \\ I am concerned about unnecessary purchase. \\ I am concerned about misuse of personal information. \\ I am concerned about receipt of unsolicited material. \\ I am concerned about receiving junk mail. \\ I am concerned about my personal information being shared. \\ I feel that credit card safety should be increased. \\ I worry about reliable delivery. \\ I am concerned about timely arrival of purchase products. \\ I like to enhance comparison shipping. \\ I am concerned I might purchase more than I need to. \\ I am concerned about impulsive buying. \\ I like assurance of arrival of purchase products. \\ I am concerned about unreasonable purchases. \\ I am concerned about timely delivery of purchased items. \\ I am concerned about accuracy of transaction. \\ I am concerned about transaction error.
}

I am concerned about fraud when I want to purchase a product or service over e-government site. 
I worry about receiving wrong products.

I am concerned about shipping errors.

I am concerned about charging errors.

I like being able to compare products.

I worry about being charged inaccurately.

I like to have greater product choice.

I feel Internet commerce helps me make better purchase decisions.

I feel Internet commerce minimizes my disappointment in purchase experience.

I feel confident in making right purchase choices.

I like having maximum product variety.

I like to have the maximum range of quality product options.

I feel there is sufficient opportunity for comparison shipping.

I like having greater product selection.

I like a broad choice of products.

I like the ease of comparison shopping.

I like to have maximum product availability.

I like to travel as little as possible to purchase.

I like an easy-to-use interface for Internet commerce.

I like simple systems for product search.

I feel human customer support is important.

I feel there should be opportunity for personal interaction.

I like to be able to talk with a salesperson.

I feel computer-based customer support is sufficient.

I like to drive as little as possible to shop.

I will be satisfied with computer-based customer support alone.

\section{Fundamental Objectives.}

It is important to maximize product value.

It is important to ensure the quality of a product.

It is important to maximize functionality of a purchased item.

It is important to minimize dispatch time.

It is important to minimize product cost.

It is important to minimize tax cost.

It is important to maximize purchasing convenience.

It is important to minimize shipping cost.

It is important to minimize Internet cost.

It is important to minimize travel cost.

It is important to get the best product for the buck.

It is important to minimize search time.

It is important to minimize time to receive product.

It is important to minimize shipping time.

It is important to maximize convenience.

It is important to minimize processing time.

It is important to minimize delivery time.

It is important to minimize disappointment.

It is important to minimize waiting time.

It is important to maximize time flexibility in purchasing.

It is important to minimize time pressure when shopping.

It is important to provide quality after-sale service.

It is important to assure an easy return process.

It is important to reduce time spent interacting with the vendor.

It is important to minimize the effort of shopping.

It is important to make shopping easy.

It is important to minimize personal hassle.

It is important to maximize ease of finding a product.

It is important to minimize purchase time. 
It is important to minimize payment time.

It is important to minimize queuing time.

It is important to avoid getting on electronic mailing lists.

It is important to minimize time to find a product.

It is important to minimize time to order a product.

It is important to minimize regret of shopping.

It is important to minimize time to gather information.

It is important to minimize time to select a product.

It is important to provide an easy return process.

It is important to reduce environmental damages.

It is important to maximize privacy.

It is important to make shopping a social event.

It is important to minimize the worry of shopping.

It is important to inspire customers.

It is important to maximize driving safety for shopping.

It is important to enhance customer productivity.

It is important to minimize pollution.

It is important to give customers new ideas.

It is important to minimize regret of online shopping.

It is important to maximize customer confidence.

It is important to minimize shopping effort.

It is important to maximize a safe shopping experience.

It is important to minimize the risk of product use.

It is important to minimize environment impact. 
Appendix B

\section{E-government Relevant Factors}

\begin{tabular}{|c|c|c|c|}
\hline Factors & Title of article & Publication & Authors \\
\hline $\begin{array}{l}\text { 1. Concerns about } \\
\text { inequities } \\
\text { among citizens } \\
\text { (digital divide) } \\
\text { 2. Usefulness of } \\
\text { information } \\
\text { (validity, } \\
\text { accuracy, } \\
\text { clarity, } \\
\text { frequency, } \\
\text { sufficiency, } \\
\text { timeliness, } \\
\text { reliability, } \\
\text { relevancy, } \\
\text { message content } \\
\text { and cost) }\end{array}$ & $\begin{array}{l}\text { E-government } \\
\text { evaluation: A } \\
\text { framework and case } \\
\text { study }\end{array}$ & $\begin{array}{l}\text { Government } \\
\text { Information Quarterly }\end{array}$ & $\begin{array}{l}\text { Gupta \& Jana } \\
\text { (2003) }\end{array}$ \\
\hline $\begin{array}{l}\text { 1. } \begin{array}{l}\text { Participation in } \\
\text { decision making } \\
\text { (comments }\end{array} \\
\text { online about } \\
\text { proposed } \\
\text { regulations) } \\
\text { 2. E-filing of } \\
\text { petitions } \\
\text { 3. Disability access } \\
\text { 4. Foreign } \\
\text { language } \\
\text { 5. Simplify data } \\
\text { access } \\
\text { 6. Security and } \\
\text { privacy }\end{array}$ & $\begin{array}{l}\text { The ongoing march } \\
\text { toward digital } \\
\text { government }\end{array}$ & Computer (IEEE) & $\begin{array}{l}\text { Elmagarmid \& } \\
\text { McIver (2001) }\end{array}$ \\
\hline $\begin{array}{l}\text { 1. } \begin{array}{l}\text { Bring citizens } \\
\text { closer to their } \\
\text { governments }\end{array} \\
\text { 2. Information } \\
\text { security and } \\
\text { privacy }\end{array}$ & $\begin{array}{l}\text { E-government for } \\
\text { Arab countries }\end{array}$ & $\begin{array}{l}\text { Journal of Global } \\
\text { Information } \\
\text { Technology } \\
\text { Management }\end{array}$ & Pons (2004) \\
\hline $\begin{array}{l}\text { 1. Linking supply } \\
\text { chain } \\
\text { 2. Using emerging }\end{array}$ & $\begin{array}{l}\text { IS research, } \\
\text { innovation, and e- } \\
\text { government }\end{array}$ & $\begin{array}{l}\text { Communications of the } \\
\text { ACM }\end{array}$ & $\begin{array}{l}\text { Scherlis \& } \\
\text { Eisenberg (2003) }\end{array}$ \\
\hline
\end{tabular}




\begin{tabular}{|c|c|c|c|}
\hline technology & & & \\
\hline 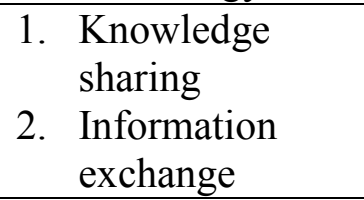 & $\begin{array}{l}\text { Knowledge } \\
\text { management in e- } \\
\text { government }\end{array}$ & $\begin{array}{l}\text { Ninth Americans } \\
\text { Conference on } \\
\text { Information Systems - } \\
2003\end{array}$ & Wagner (2003) \\
\hline $\begin{array}{l}\text { 1. Greater } \\
\text { government } \\
\text { accountability }\end{array}$ & $\begin{array}{l}\text { Public expectations } \\
\text { and public scrutiny: } \\
\text { An agenda for } \\
\text { research in the } \\
\text { context of e- } \\
\text { government }\end{array}$ & $\begin{array}{l}\text { Ninth Americans } \\
\text { Conference on } \\
\text { Information Systems - } \\
2003\end{array}$ & $\begin{array}{l}\text { Jain \& } \\
\text { Patnayakuni } \\
\text { (2003) }\end{array}$ \\
\hline $\begin{array}{l}\text { 1. } \begin{array}{l}\text { Collaboration } \\
\text { between federal, } \\
\text { state, and local } \\
\text { governments }\end{array} \\
\text { 2. Accountable } \\
\text { government } \\
\text { 3. Increased } \\
\text { geospatial } \\
\text { information }\end{array}$ & $\begin{array}{l}\text { Expanding } \\
\text { electronic } \\
\text { government: The } \\
\text { challenges }\end{array}$ & The Public Manager & Pandy (2002) \\
\hline $\begin{array}{l}\text { 1. Communication } \\
\text { and public } \\
\text { relations tool } \\
\text { 2. Promoting } \\
\text { public } \\
\text { participation in } \\
\text { policy-making } \\
\text { process }\end{array}$ & $\begin{array}{l}\text { The evolution of e- } \\
\text { government among } \\
\text { municipalities: } \\
\text { Rhetoric or reality? }\end{array}$ & $\begin{array}{l}\text { Public Administration } \\
\text { Review }\end{array}$ & Moon (2002) \\
\hline $\begin{array}{l}\text { 1. } \begin{array}{l}\text { Security and } \\
\text { privacy concern. }\end{array} \\
\text { 2. Improved } \\
\text { communication }\end{array}$ & $\begin{array}{l}\text { Same bed, different } \\
\text { dreams?: A } \\
\text { comparative } \\
\text { analysis of citizen } \\
\text { and bureaucrat } \\
\text { perspectives on e- } \\
\text { government }\end{array}$ & $\begin{array}{l}\text { Proceedings of the } 37^{\text {th }} \\
\text { Hawaii International } \\
\text { conference on Systems } \\
\text { Sciences }\end{array}$ & $\begin{array}{l}\text { Moon \& Welch } \\
\text { (2004) }\end{array}$ \\
\hline $\begin{aligned} & \text { 1. } \text { Information } \\
& \text { retrieval } \\
& \text { 2. } \\
& \text { Effective } \\
& \text { communication } \\
& \text { with citizens } \\
& \text { 3. Timeliness of } \\
& \text { response }\end{aligned}$ & $\begin{array}{l}\text { Facing the } \\
\text { challenges of e- } \\
\text { government: A case } \\
\text { study of the city of } \\
\text { Corpus Christi, } \\
\text { Texas }\end{array}$ & $\begin{array}{l}\text { S.A.M. Advanced } \\
\text { Management Journal }\end{array}$ & $\begin{array}{l}\text { Jorgensen \& } \\
\text { Cable (2002) }\end{array}$ \\
\hline 1. E-democracy & $\begin{array}{l}\text { Emerging electronic } \\
\text { infrastructures: } \\
\text { Exploring } \\
\text { democratic }\end{array}$ & $\begin{array}{l}\text { Social Science } \\
\text { Computer Review }\end{array}$ & Gronlund (2003) \\
\hline
\end{tabular}




\begin{tabular}{|c|c|c|c|}
\hline & components & & \\
\hline $\begin{array}{l}\text { 1. Transparent } \\
\text { government } \\
\text { 2. Two-way } \\
\text { interaction }\end{array}$ & $\begin{array}{l}\text { National } \\
\text { information policy } \\
\text { developments } \\
\text { worldwide: } \\
\text { Electronic } \\
\text { government }\end{array}$ & $\begin{array}{l}\text { Journal of Information } \\
\text { Science }\end{array}$ & $\begin{array}{l}\text { Muir \& } \\
\text { Oppenheim } \\
(2002)\end{array}$ \\
\hline $\begin{array}{l}\text { 1. Billboard } \\
\text { features, such as } \\
\text { contact } \\
\text { information, } \\
\text { publications, } \\
\text { and databases } \\
\text { 2. Improved } \\
\text { service delivery } \\
\text { 3. Public outreach } \\
\text { and democracy } \\
\text { enhancement }\end{array}$ & $\begin{array}{l}\text { E-government and } \\
\text { the transformation } \\
\text { of service delivery } \\
\text { and citizen attitudes }\end{array}$ & $\begin{array}{l}\text { Public Administration } \\
\text { Review }\end{array}$ & West (2004) \\
\hline $\begin{array}{ll}\text { 1. } & \text { Facilitated } \\
\text { access to public } \\
\text { information and } \\
\text { services } \\
\text { 2. } \\
\text { Improved } \\
\text { transparency of } \\
\text { administration }\end{array}$ & $\begin{array}{l}\text { Technology push, } \\
\text { legislation pull? E- } \\
\text { government in the } \\
\text { European Union }\end{array}$ & $\begin{array}{l}\text { Decision Support } \\
\text { Systems }\end{array}$ & $\begin{array}{l}\text { Strejcek \& Theil } \\
\text { (2002) }\end{array}$ \\
\hline $\begin{array}{l}\text { 1. Broad supply of } \\
\text { information and } \\
\text { communication } \\
\text { services } \\
\text { 2. Increased } \\
\text { transaction } \\
\text { function }\end{array}$ & $\begin{array}{l}\text { Electronic } \\
\text { government services } \\
\text { for the business } \\
\text { sector in Austria }\end{array}$ & $\begin{array}{l}\text { Proceedings of the } 12^{\text {th }} \\
\text { International Workshop } \\
\text { on Database and Expert } \\
\text { Systems Applications }\end{array}$ & $\begin{array}{l}\text { Aichholzer \& } \\
\text { Sperlich (2001) }\end{array}$ \\
\hline $\begin{array}{ll}\text { 1. } & \text { Increased } \\
\text { transaction } \\
\text { services } \\
\text { 2. } & \text { Participatory } \\
\text { government }\end{array}$ & $\begin{array}{l}\text { Evolution of local } \\
\text { government e- } \\
\text { services: The } \\
\text { applicability of e- } \\
\text { business maturity } \\
\text { models }\end{array}$ & $\begin{array}{l}\text { Proceedings of the } 37^{\text {th }} \\
\text { Hawaii International } \\
\text { Conference on Systems } \\
\text { Sciences }\end{array}$ & $\begin{array}{l}\text { Shackleton, } \\
\text { Fisher, \& } \\
\text { Dawson (2004) }\end{array}$ \\
\hline $\begin{array}{ll}\text { 1. } & \text { Access to } \\
\text { information } \\
\text { 2. Ease of } \\
\text { interaction } \\
\text { 3. E-democracy }\end{array}$ & $\begin{array}{l}\text { Towards citizen- } \\
\text { centered local e- } \\
\text { government - the } \\
\text { case of City of } \\
\text { Tampere }\end{array}$ & $\begin{array}{l}\text { University of Tampere, } \\
\text { Finland }\end{array}$ & $\begin{array}{l}\text { Anttiroiko } \\
\text { (2004) }\end{array}$ \\
\hline $\begin{array}{l}\text { 1. Sufficient } \\
\text { supply of }\end{array}$ & $\begin{array}{l}\text { E-business, e- } \\
\text { government \& }\end{array}$ & $\begin{array}{l}\text { The Information } \\
\text { Management Journal }\end{array}$ & Dearstyne (2001) \\
\hline
\end{tabular}




\begin{tabular}{|c|c|c|c|}
\hline $\begin{array}{l}\text { information and } \\
\text { services } \\
\text { 2. } \\
\text { Transparent } \\
\text { government }\end{array}$ & $\begin{array}{l}\text { information } \\
\text { proficiency }\end{array}$ & & \\
\hline 1. Ease of contact & $\begin{array}{l}\text { The new face of } \\
\text { government: } \\
\text { Citizen-initiated } \\
\text { contacts in the era } \\
\text { of e-government }\end{array}$ & $\begin{array}{l}\text { Journal of Public } \\
\text { Administration } \\
\text { Research and Theory }\end{array}$ & $\begin{array}{l}\text { Thomas \& Streib } \\
\text { (2003) }\end{array}$ \\
\hline 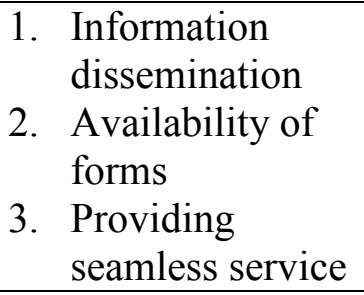 & $\begin{array}{l}\text { E-government 2001: } \\
\text { Understanding the } \\
\text { challenge and } \\
\text { evolving strategies }\end{array}$ & The Public Manager & Balutis (2001A) \\
\hline $\begin{array}{l}\text { 1. Availability of } \\
\text { information and } \\
\text { service delivery } \\
\text { online } \\
\text { 2. Ease of } \\
\text { interaction }\end{array}$ & $\begin{array}{l}\text { E-government } \\
\text { around the world }\end{array}$ & $\begin{array}{l}\text { Information } \\
\text { Management Journal }\end{array}$ & Swartz (2004) \\
\hline 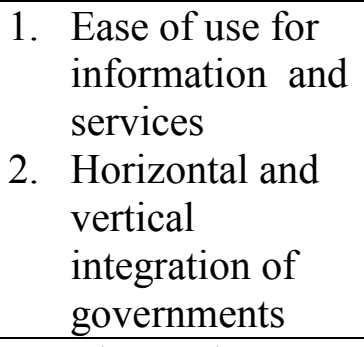 & $\begin{array}{l}\text { E-government and } \\
\text { performance: A } \\
\text { citizen-centered } \\
\text { imperative }\end{array}$ & The Public Manager & Wert (2002) \\
\hline 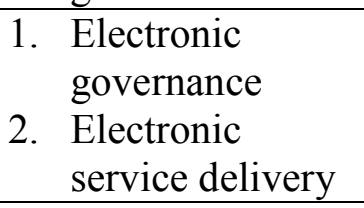 & $\begin{array}{l}\text { Introduction: E- } \\
\text { government }\end{array}$ & $\begin{array}{l}\text { Social Science } \\
\text { Computer Review }\end{array}$ & Roy (2003) \\
\hline $\begin{array}{ll}\text { 1. } & \text { Services } \\
\text { provided by } \\
\text { function as } \\
\text { opposed to by } \\
\text { department } \\
\text { 2. } \\
\text { Democratic } \\
\text { participation }\end{array}$ & $\begin{array}{l}\text { Managing the } \\
\text { transformation to e- } \\
\text { government: An } \\
\text { Australian } \\
\text { perspective }\end{array}$ & $\begin{array}{l}\text { Thunderbird } \\
\text { International Business } \\
\text { Review }\end{array}$ & Clark (2003) \\
\hline $\begin{array}{l}\text { 1. One stop portal } \\
\text { 2. Citizen-centered } \\
\text { facility }\end{array}$ & $\begin{array}{l}\text { Innovation in } \\
\text { American e- } \\
\text { government: } \\
\text { FirstGov.gov }\end{array}$ & The Public Manager & McGinnis (2003) \\
\hline $\begin{array}{l}\text { 1. Useful service } \\
\text { 2. Convenience of } \\
\text { online service }\end{array}$ & $\begin{array}{l}\text { Citizen adoption of } \\
\text { electronic } \\
\text { government }\end{array}$ & $\begin{array}{l}\text { Proceedings of the } 37^{\text {th }} \\
\text { Hawaii International } \\
\text { Conference on Systems }\end{array}$ & $\begin{array}{l}\text { Carter \& } \\
\text { Belanger (2004) }\end{array}$ \\
\hline
\end{tabular}




\begin{tabular}{|c|c|c|c|}
\hline $\begin{array}{l}\text { 3. Compatibility of } \\
\text { life style }\end{array}$ & initiatives & Sciences & \\
\hline $\begin{array}{ll}\text { 1. } & \text { Improved } \\
\text { service delivery } \\
\text { 2. } \\
\text { Democratic } \\
\text { responsiveness } \\
\text { 3. Public outreach }\end{array}$ & $\begin{array}{l}\text { E-government and } \\
\text { the transformation } \\
\text { of service delivery } \\
\text { and citizen attitudes }\end{array}$ & $\begin{array}{l}\text { Public Administration } \\
\text { Review }\end{array}$ & West (2004) \\
\hline $\begin{array}{l}\text { 1. Broad range of } \\
\text { e-government } \\
\text { services }\end{array}$ & $\begin{array}{l}\text { Capacity and e- } \\
\text { government } \\
\text { performance }\end{array}$ & $\begin{array}{l}\text { Public Performance \& } \\
\text { Management Review }\end{array}$ & Melitski (2003) \\
\hline $\begin{array}{l}\text { 1. Information } \\
\text { format desired } \\
\text { by users }\end{array}$ & $\begin{array}{l}\text { Designing } \\
\text { government } \\
\text { information access } \\
\text { programs: A holistic } \\
\text { approach }\end{array}$ & $\begin{array}{l}\text { Proceedings of the } 36^{\text {th }} \\
\text { Hawaii International } \\
\text { Conference on Systems } \\
\text { Sciences }\end{array}$ & $\begin{array}{l}\text { Dawes, Pardo, \& } \\
\text { Cresswell (2003) }\end{array}$ \\
\hline $\begin{array}{l}\text { 1. } \begin{array}{l}\text { Convenient and } \\
\text { costless e- } \\
\text { government } \\
\text { services }\end{array} \\
\end{array}$ & $\begin{array}{l}\text { Measuring the } \\
\text { performance of } \\
\text { electronic } \\
\text { government services }\end{array}$ & $\begin{array}{l}\text { Information \& } \\
\text { Management }\end{array}$ & Steyaert (2004) \\
\hline $\begin{array}{l}\text { 1. Integrated } \\
\text { access structure }\end{array}$ & $\begin{array}{l}\text { A framework for } \\
\text { electronic } \\
\text { government }\end{array}$ & $\begin{array}{l}\text { Proceedings of the } 11^{\text {th }} \\
\text { International Workshop } \\
\text { on Database and Expert } \\
\text { Systems Applications }\end{array}$ & $\begin{array}{l}\text { Lenk \& } \\
\text { Traunmuller } \\
(2000)\end{array}$ \\
\hline $\begin{array}{ll}\text { 1. } & \text { Seamless } \\
\text { government } \\
\text { 2. } & \text { Electronic } \\
\text { democracy }\end{array}$ & $\begin{array}{l}\text { Trends in electronic } \\
\text { government: } \\
\text { Managing } \\
\text { distributed } \\
\text { knowledge }\end{array}$ & $\begin{array}{l}\text { Proceedings of the } 11^{\text {th }} \\
\text { International Workshop } \\
\text { on Database and Expert } \\
\text { systems Applications }\end{array}$ & $\begin{array}{l}\text { Wimmer \& } \\
\text { Traunmuller } \\
(2000)\end{array}$ \\
\hline $\begin{array}{l}\text { 1. Free Internet } \\
\text { access to e- } \\
\text { government }\end{array}$ & $\begin{array}{l}\text { Adoption of e- } \\
\text { governance: } \\
\text { Difference between } \\
\text { countries in the use } \\
\text { of online } \\
\text { government services }\end{array}$ & $\begin{array}{l}\text { Journal of American } \\
\text { Academy of Business }\end{array}$ & Prattipati (2003) \\
\hline $\begin{array}{ll}\text { 1. } & \text { Enhanced } \\
\text { information } \\
\text { dissemination } \\
\text { 2. } \\
\text { Increased } \\
\text { transaction } \\
\text { online }\end{array}$ & $\begin{array}{l}\text { E-government } 2001 \text {, } \\
\text { part II: Evolving } \\
\text { strategies for action }\end{array}$ & The Public Manager & Balutis (2001B) \\
\hline $\begin{array}{l}\text { 1. Security } \\
\text { 2. Privacy }\end{array}$ & $\begin{array}{l}\text { A framework for e- } \\
\text { governance } \\
\text { solutions }\end{array}$ & $\begin{array}{l}\text { IBM Journal of } \\
\text { Research and } \\
\text { Development }\end{array}$ & $\begin{array}{l}\text { Mittal, Kumar, } \\
\text { Mohania, Nair, } \\
\text { Batra, Roy, } \\
\text { Saronwala, \& } \\
\text { Yagnik (2004) }\end{array}$ \\
\hline
\end{tabular}




\begin{tabular}{|c|c|c|c|}
\hline $\begin{array}{l}\text { 1. One-stop service } \\
\text { 2. Privacy }\end{array}$ & $\begin{array}{l}\text { Electronic service } \\
\text { delivery - a driver } \\
\text { of public sector } \\
\text { modernization. }\end{array}$ & Information Polity & Lenk (2002). \\
\hline $\begin{array}{l}\text { 1. Greater public } \\
\text { access to } \\
\text { information } \\
\text { 2. Convenient } \\
\text { government } \\
\text { services }\end{array}$ & $\begin{array}{l}\text { E-government: The } \\
\text { next American } \\
\text { revolution }\end{array}$ & $\begin{array}{l}\text { Council for Excellence } \\
\text { in Government }\end{array}$ & $\begin{array}{l}\text { Council for } \\
\text { Excellence in } \\
\text { Government } \\
(2001)\end{array}$ \\
\hline $\begin{array}{l}\text { 1. } 24 \times 7 \text { availability } \\
\text { of services }\end{array}$ & $\begin{array}{l}\text { Planning local e- } \\
\text { government }\end{array}$ & $\begin{array}{l}\text { Information Systems } \\
\text { Management }\end{array}$ & $\begin{array}{l}\text { Vriens \& } \\
\text { Achterbergh } \\
(2004)\end{array}$ \\
\hline 1. Fast service & $\begin{array}{l}\text { Infrastructure for e- } \\
\text { government Web } \\
\text { services }\end{array}$ & $\begin{array}{l}\text { IEEE Internet } \\
\text { Computing }\end{array}$ & $\begin{array}{l}\text { Medjahed, } \\
\text { Rezgui, } \\
\text { Bouguettaya, \& } \\
\text { Ouzzani, } \\
\text { Jan/Feb, 2003). }\end{array}$ \\
\hline $\begin{array}{ll}\text { 1. } & \text { Improved } \\
\text { service } \\
\text { 2. } & \text { Fast delivery of } \\
\text { information }\end{array}$ & $\begin{array}{l}\text { An application } \\
\text { within the plan for } \\
\text { e-government: the } \\
\text { workfare portal }\end{array}$ & University of Milano & $\begin{array}{l}\text { Fugini \& } \\
\text { Mezzanzanica } \\
(2004)\end{array}$ \\
\hline
\end{tabular}




\section{Appendix C}

The Functional Performance Dimensions That Reflect the Common Municipality

Functions and Services That Can Be Web-enabled (Kaylor et al., 2001).

\begin{tabular}{|c|c|}
\hline $\begin{array}{ll}\text { Payments } \\
\text { - Utilities } \\
\text { - Taxes } \\
\text { - } \text { Fines } \\
\text { - } \text { Permits } \\
\text { - } & \text { Registrations }\end{array}$ & $\begin{array}{l}\text { Images } \\
\text { - } \quad \text { GIS Online } \\
\text { - } \text { AS-built Images } \\
\text { - } \quad \text { Plat Maps } \\
\end{array}$ \\
\hline \begin{tabular}{ll}
\multicolumn{2}{l}{ Registration } \\
- & Facilities \\
- & Classes \\
- & Voters
\end{tabular} & \multirow{2}{*}{$\begin{array}{l}\text { Audio/Video } \\
\text { - Streaming Video of City Council } \\
\text { Meetings } \\
\text { - } \text { Live Traffic Cams } \\
\text { - Auto-only Broadcast of Council } \\
\text { Meetings } \\
\text { - Video or Still-image Tour of Town } \\
\text { - Video Walk-through Directions to } \\
\text { Departments/Facilities } \\
\end{array}$} \\
\hline $\begin{array}{l}\text { Applications } \\
\text { - Job Applications } \\
\text { - } \text { Bidder Applications } \\
\text { - } \text { Affirmative Action Forms }\end{array}$ & \\
\hline $\begin{array}{ll}\text { Permits } \\
\text { - } & \text { Building } \\
\text { - } & \text { Parking } \\
\text { - } & \text { Temporary Use } \\
\text { - } & \text { Right-of-Way } \\
\text { - } & \text { Street Vendor } \\
\text { - } & \text { Sidewalk Dining } \\
\end{array}$ & $\begin{array}{l}\text { Documents } \\
\text { - } \text { Minutes of Meetings } \\
\text { - City Code } \\
\text { - } \text { City Charter } \\
\text { - } \text { Budget Report } \\
\text { - } \quad \text { Downloadable Forms }\end{array}$ \\
\hline \multirow{3}{*}{$\begin{array}{ll}\text { Customer Service } \\
\text { - } & \text { Action Requests (Complaints) } \\
\text { - } & \text { Code Enforcement } \\
\text { - } & \text { Parking Referee } \\
\text { - } & \text { Payment Histories } \\
\text { - } & \text { Schedules (Hours of Operation) } \\
\text { - } & \text { Utility Start/Stop } \\
\text { - } & \text { Information Requests }\end{array}$} & $\begin{array}{l}\text { E-Procurement } \\
\text { - Bids Online }\end{array}$ \\
\hline & $\begin{array}{ll}\text { Licenses } \\
- & \text { Bike } \\
- & \text { Dog } \\
- & \text { Taxi } \\
- & \text { Business } \\
\end{array}$ \\
\hline & \multirow{2}{*}{$\begin{array}{l}\text { Miscellaneous } \\
\text { - } \quad \text { Property Assessment History Lookup } \\
\text { - Zoning Lookup } \\
\text { - } \text { Online Surveys/Polls } \\
\text { - } \quad \text { Conversation Forums } \\
\text { - } \quad \text { Scheduled E-meetings }\end{array}$} \\
\hline $\begin{array}{ll}\text { Communication } \\
\text { - } & \text { Incidental Closure } \\
\text { - } & \text { Emergency Management } \\
\text { - } & \text { Road Closure/Detour } \\
\end{array}$ & \\
\hline
\end{tabular}




\section{Appendix D}

\section{Survey Instrument}

\section{$\underline{\text { E-government Experience Survey (by Ronnie Park) }}$}

Thank you for participating in this e-government research survey. Your responses will contribute to research that will be used to provide more efficient and convenient online government services.

Below is a list of 76 statements regarding the use of e-government online services.

Please rate the importance for each item, from "strongly disagree" to "strongly agree."

Means Objectives

Strongly $\quad$ Strongly

I like the opportunity for two-way interaction.

Disagree Disagree Neutral Agree Agree

$\begin{array}{lllllllll}\text { I like the opportunity for personal interaction. } & \mathrm{O} & \mathrm{O} & \mathrm{O} & \mathrm{O} & \mathrm{O}\end{array}$

I like to promote universal access that will allow all

$\begin{array}{lllll}\mathrm{O} & \mathrm{O} & \mathrm{O} & \mathrm{O} & \mathrm{O}\end{array}$ citizens to easily and conveniently interact with egovernment.

I like to minimize the digital divide demarcated by wealth, age, language, culture, geographical location, etc.

I feel accessibility for individuals with special needs (e.g., disabilities) should be maximized.

I like to participate electronically and directly in decision making.

I like to voice my preferences regarding policies.

I like to promote knowledge sharing between the government and its citizens.

I like to promote e-services (e.g., voting online, discussing public issues online, etc.)

$\begin{array}{lllll}\mathrm{O} & \mathrm{O} & \mathrm{O} & \mathrm{O} & \mathrm{O}\end{array}$

$\begin{array}{lllll}\mathrm{O} & \mathrm{O} & \mathrm{O} & \mathrm{O} & \mathrm{O}\end{array}$

$\begin{array}{lllll}\mathrm{O} & \mathrm{O} & \mathrm{O} & \mathrm{O} & \mathrm{O}\end{array}$

$\begin{array}{lllll}\mathrm{O} & \mathrm{O} & \mathrm{O} & \mathrm{O} & \mathrm{O}\end{array}$

$\begin{array}{lllll}\mathrm{O} & \mathrm{O} & \mathrm{O} & \mathrm{O} & \mathrm{O}\end{array}$

$\begin{array}{lllll}\mathrm{O} & \mathrm{O} & \mathrm{O} & \mathrm{O} & \mathrm{O}\end{array}$ 
I am concerned about how much I can trust the government.

I like to promote transparency in government.

I like to promote fairness, providing non-

discriminatory service.

I like to promote public outreach.

I like to have horizontal integration of government services (linking different functions of government with each other).

I like to have vertical integration of government services (linking different levels of government, such as local, state, and federal).

I like to facilitate information dissemination.

I like to have information on demand.

I like to have search criteria.

I like have a great amount of information.

I like to have up-to-date information.

I like to have a choice of information.

I like to minimize the risk of skipping or missing information.

I like to get as much information about services as possible.

I like seeing greater use of style and format in Web site design.

I like to make e-government services more appealing to the average person.

I like to promote ease of viewing.

I like to have a variety of foreign language options available to people.
$\mathrm{O} \quad \mathrm{O} \quad \mathrm{O} \quad \mathrm{O} \quad \mathrm{O}$

O $\quad \mathrm{O} \quad \mathrm{O} \quad \mathrm{O} \quad \mathrm{O}$

$\mathrm{O} \quad \mathrm{O} \quad \mathrm{O} \quad \mathrm{O} \quad \mathrm{O}$

$\begin{array}{lllll}\mathrm{O} & \mathrm{O} & \mathrm{O} & \mathrm{O} & \mathrm{O}\end{array}$

$\begin{array}{lllll}\mathrm{O} & \mathrm{O} & \mathrm{O} & \mathrm{O} & \mathrm{O}\end{array}$

$\begin{array}{lllll}\mathrm{O} & \mathrm{O} & \mathrm{O} & \mathrm{O} & \mathrm{O}\end{array}$

$\begin{array}{lllll}\mathrm{O} & \mathrm{O} & \mathrm{O} & \mathrm{O}\end{array}$

$\begin{array}{lllll} & \mathrm{O} & \mathrm{O} & \mathrm{O} & \mathrm{O}\end{array}$

$\begin{array}{lllll}\mathrm{O} & \mathrm{O} & \mathrm{O} & \mathrm{O}\end{array}$

$\begin{array}{lllll}\mathrm{O} & \mathrm{O} & \mathrm{O} & \mathrm{O} & \mathrm{O}\end{array}$

$\begin{array}{lllll}\mathrm{O} & \mathrm{O} & \mathrm{O} & \mathrm{O} & \mathrm{O}\end{array}$

$\begin{array}{lllll}\mathrm{O} & \mathrm{O} & \mathrm{O} & \mathrm{O} & \mathrm{O}\end{array}$

$\begin{array}{lllll}\mathrm{O} & \mathrm{O} & \mathrm{O} & \mathrm{O} & \mathrm{O}\end{array}$

$\begin{array}{lllll}\mathrm{O} & \mathrm{O} & \mathrm{O} & \mathrm{O}\end{array}$

$\begin{array}{lllll}\mathrm{O} & \mathrm{O} & \mathrm{O} & \mathrm{O} & \mathrm{O}\end{array}$

$\begin{array}{lllll}\mathrm{O} & \mathrm{O} & \mathrm{O} & \mathrm{O} & \mathrm{O}\end{array}$

$\begin{array}{lllll}\mathrm{O} & \mathrm{O} & \mathrm{O} & \mathrm{O}\end{array}$

$\begin{array}{lllll}\mathrm{O} & \mathrm{O} & \mathrm{O} & \mathrm{O} & \mathrm{O}\end{array}$ 
I like to have e-government systems agreeing and implementing global standards (e.g., e-signature identification).

I like to discourage unauthorized access.

$\begin{array}{lllll}\mathrm{O} & \mathrm{O} & \mathrm{O} & \mathrm{O} & \mathrm{O}\end{array}$

I like to discourage hacking.

$\begin{array}{lllll}\mathrm{O} & \mathrm{O} & \mathrm{O} & \mathrm{O} & \mathrm{O}\end{array}$

I am concerned about transaction security.

$\begin{array}{lllll}\mathrm{O} & \mathrm{O} & \mathrm{O} & \mathrm{O} & \mathrm{O}\end{array}$

I am concerned about misuse of my credit card.

$\begin{array}{lllll}\mathrm{O} & \mathrm{O} & \mathrm{O} & \mathrm{O} & \mathrm{O}\end{array}$

I am concerned about identity theft.

$\begin{array}{lllll}\mathrm{O} & \mathrm{O} & \mathrm{O} & \mathrm{O} & \mathrm{O}\end{array}$

I am concerned about privacy risks.

$\begin{array}{lllll}\mathrm{O} & \mathrm{O} & \mathrm{O} & \mathrm{O} & \mathrm{O}\end{array}$

I am concerned about the safeguarding of personal

$\begin{array}{lllll}\mathrm{O} & \mathrm{O} & \mathrm{O} & \mathrm{O} & \mathrm{O}\end{array}$

information.

I am concerned about sharing of personal information. $\begin{array}{lllllll}\mathrm{O} & \mathrm{O} & \mathrm{O} & \mathrm{O} & \mathrm{O}\end{array}$

$\begin{array}{llllll}\text { I am concerned about receiving unsolicited material. } & \mathrm{O} & \mathrm{O} & \mathrm{O} & \mathrm{O} & \mathrm{O}\end{array}$

$\begin{array}{lllllll}\text { I am concerned about reliable delivery of information } & \mathrm{O} & \mathrm{O} & \mathrm{O} & \mathrm{O} & \mathrm{O}\end{array}$ and services.

I am concerned about quality of the information and $\quad \begin{array}{lllllllll}\mathrm{O} & \mathrm{O} & \mathrm{O} & \mathrm{O} & \mathrm{O}\end{array}$ services delivered.

I am concerned about accuracy of transaction.

$\mathrm{O} \quad \mathrm{O} \quad \mathrm{O} \quad \mathrm{O} \quad \mathrm{O}$

I am concerned about charging errors.

$\begin{array}{lllll}\mathrm{O} & \mathrm{O} & \mathrm{O} & \mathrm{O} & \mathrm{O}\end{array}$

I like to have new types of services.

$\mathrm{O} \quad \mathrm{O} \quad \mathrm{O} \quad \mathrm{O} \quad \mathrm{O}$

$\begin{array}{lllllll}\text { I feel that new services should be made as convenient } & \mathrm{O} & \mathrm{O} & \mathrm{O} & \mathrm{O} & \mathrm{O}\end{array}$ as possible utilizing various devices, such as cell phones, PDAs, etc.

I feel ease of accessing information and services is important.

I feel ease of search process is important.

I feel ease of use for information and services is important.

$\begin{array}{lllll}\mathrm{O} & \mathrm{O} & \mathrm{O} & \mathrm{O} & \mathrm{O}\end{array}$

$\begin{array}{lllll}\mathrm{O} & \mathrm{O} & \mathrm{O} & \mathrm{O} & \mathrm{O}\end{array}$

$\mathrm{O} \quad \mathrm{O} \quad \mathrm{O} \quad \mathrm{O} \quad \mathrm{O}$ 
I like to have compatibility between e-government services and older "legacy" services (e.g., paper based

$\mathrm{O} \quad \mathrm{O} \quad \mathrm{O} \quad \mathrm{O} \quad \mathrm{O}$ system).

Fundamental Objectives

It is important to optimize citizen satisfaction.

It is important to always consider overall good of

$\begin{array}{lllll}\mathrm{O} & \mathrm{O} & \mathrm{O} & \mathrm{O} & \mathrm{O}\end{array}$

society.

It is important to ensure time flexibility in using

$\begin{array}{lllll}\mathrm{O} & \mathrm{O} & \mathrm{O} & \mathrm{O} & \mathrm{O}\end{array}$

services.

It is important to offer personal interaction.

$\begin{array}{lllll}\mathrm{O} & \mathrm{O} & \mathrm{O} & \mathrm{O} & \mathrm{O}\end{array}$

It is important to reduce effort in receiving service. $\quad \begin{array}{llllllllllll} & \mathrm{O} & \mathrm{O} & \mathrm{O} & \mathrm{O} & \mathrm{O}\end{array}$

$\begin{array}{lllllll}\text { It is important to minimize personal hassle. } & \mathrm{O} & \mathrm{O} & \mathrm{O} & \mathrm{O} & \mathrm{O}\end{array}$

It is important to find information and services easily. $\begin{array}{llllll}\mathrm{O} & \mathrm{O} & \mathrm{O} & \mathrm{O} & \mathrm{O}\end{array}$

It is important that information and services are useful. $\begin{array}{llllll}\mathrm{O} & \mathrm{O} & \mathrm{O} & \mathrm{O} & \mathrm{O}\end{array}$

$\begin{array}{lllllll}\text { It is important to keep down the cost of services. } & \mathrm{O} & \mathrm{O} & \mathrm{O} & \mathrm{O} & \mathrm{O}\end{array}$

$\begin{array}{lllllll}\text { It is important to minimize travel costs. } & \mathrm{O} & \mathrm{O} & \mathrm{O} & \mathrm{O} & \mathrm{O}\end{array}$

It is important to make communication cost efficient. $\quad \begin{array}{lllllll}\mathrm{O} & \mathrm{O} & \mathrm{O} & \mathrm{O} & \mathrm{O}\end{array}$

It is important to minimize the time it takes to find $\quad \begin{array}{llllll}\mathrm{O} & \mathrm{O} & \mathrm{O} & \mathrm{O} & \mathrm{O}\end{array}$ information and services.

It is important to minimize processing time.

$\mathrm{O} \quad \mathrm{O} \quad \mathrm{O} \quad \mathrm{O} \quad \mathrm{O}$

It is important to minimize search time.

$\mathrm{O} \quad \mathrm{O} \quad \mathrm{O} \quad \mathrm{O} \quad \mathrm{O}$

It is important to minimize payment time.

$\begin{array}{lllll}\mathrm{O} & \mathrm{O} & \mathrm{O} & \mathrm{O} & \mathrm{O}\end{array}$

It is important to minimize overall communication

$\begin{array}{lllll}\mathrm{O} & \mathrm{O} & \mathrm{O} & \mathrm{O} & \mathrm{O}\end{array}$ time.

It is important to minimize the time it takes to select information and services.

$\begin{array}{lllll}\mathrm{O} & \mathrm{O} & \mathrm{O} & \mathrm{O} & \mathrm{O}\end{array}$

It is important to respond quickly to requests for information and services.

$\begin{array}{lllll}\mathrm{O} & \mathrm{O} & \mathrm{O} & \mathrm{O} & \mathrm{O}\end{array}$ 
It is important to ensure quick delivery of information $\begin{array}{lllllll}\mathrm{O} & \mathrm{O} & \mathrm{O} & \mathrm{O} & \mathrm{O}\end{array}$ and services.

It is important to minimize shipping time.

$\mathrm{O} \quad \mathrm{O} \quad \mathrm{O} \quad \mathrm{O} \quad \mathrm{O}$

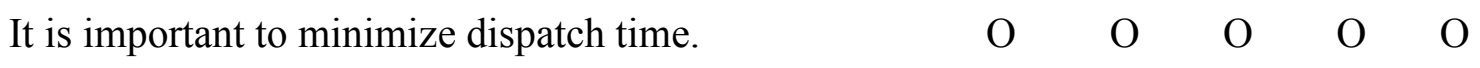

$\begin{array}{llllllll}\text { It is important to make using e-government a social } & \mathrm{O} & \mathrm{O} & \mathrm{O} & \mathrm{O} & \mathrm{O}\end{array}$ event (e.g., e-forum).

It is important to bring government services closer to citizens.

It is important to inspire citizens to use e-government $\quad \begin{array}{llllllllllll}O & O & O & O & O\end{array}$ online services.

It is important to avoid giving citizens cause to regret $\quad \begin{array}{lllllllllll}\mathrm{O} & \mathrm{O} & \mathrm{O} & \mathrm{O} & \mathrm{O}\end{array}$ using e-government online services.

It is important to minimize unnecessary driving through the advantages of having services accessible from home (e.g., parking, accident, etc.).

It is important to minimize pollution.

It is important to minimize environmental impact.

$\begin{array}{lllll}\mathrm{O} & \mathrm{O} & \mathrm{O} & \mathrm{O} & \mathrm{O}\end{array}$

O

$\begin{array}{lllll}\mathrm{O} & \mathrm{O} & \mathrm{O} & \mathrm{O}\end{array}$

$\begin{array}{lllll}\mathrm{O} & \mathrm{O} & \mathrm{O} & \mathrm{O}\end{array}$

$\begin{array}{lllll}\mathrm{O} & \mathrm{O} & \mathrm{O} & \mathrm{O}\end{array}$ 


\section{Appendix E}

Research Pool From Which E-government Values are Drawn (With One Reference Provided)

1. Information \& Management (Steyaert, 2004)

2. Information Systems Management (Vriens \& Achterbergh, 2004)

3. Communications of the ACM (Scherlis \& Eisenberg, 2003)

4. Decision Support Systems (Strejcek \& Theil, 2002)

5. Computer (IEEE) (Elmagarmid \& McIver, 2001)

6. Journal of Global Information Technology Management (Pons, 2004)

7. Ninth Americans Conference on Information Systems (Wagner, 2003)

8. The Public Manager (Pandy, 2002)

9. Public Administration Review (West, 2004)

10. Proceedings of the $36^{\text {th }}$ Hawaii International conference on Systems Sciences (Dawes, Pardo, \& Cresswell, 2003)

11. S.A.M. Advanced Management Journal (Jorgensen \& Cable, 2002)

12. Social Science Computer Review (Gronlund, 2003)

13. Journal of Information Science (Muir \& Oppenheim, 2002)

14. Public Administration Review (Moon, 2002)

15. Proceedings of the 12th International Workshop on Database and Expert Systems Applications (Aichholzer \& Sperlich, 2001)

16. Proceedings of the $37^{\text {th }}$ Hawaii International Conference on Systems Sciences (Moon \& Welch, 2004)

17. University of Tampere, Finland (Anttiroiko, 2004)

18. Information Management Journal (Dearstyne, 2001)

19. Journal of Public Administration Research and Theory (Thomas \& Streib, 2003)

20. Thunderbird International Business Review (Clark, 2003)

21. Public Performance \& Management Review (Melitski, 2003)

22. Proceedings of the $11^{\text {th }}$ International Workshop on Database and Expert Systems Applications (Lenk \& Traunmuller, 2000)

23. Government Information Quarterly (Gupta \& Jana, 2003)

24. Journal of American Academy of Business (Prattipati, 2003)

25. IBM Journal of Research and Development (Mittal, Kumar, Mohania, Nair, Batra, Roy, Saronwala, \& Yagnik, 2004)

26. Information Polity (Lenk, (2002)

27. Council for Excellence in Government (Council for Excellence in Government, 2001)

28. IEEE Internet Computing (Medjahed, Rezgui, Bouguettaya, \& Ouzzani, 2003)

29. University of Milano, Italy (Fugini \& Mezzanzanica, 2004) 


\section{Appendix F}

\section{NSU IRB Approval Letter}

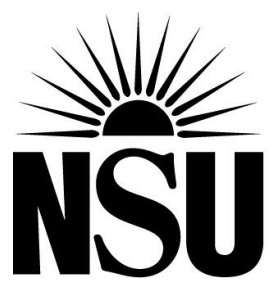

May 15, 2005

JDC:jdc

\section{MEMORANDUM}

From: James Cannady, Ph.D., Associate Professor, GSCIS

To: $\quad$ Ronnie Park

Subject: IRB Approval

After reviewing your IRB Submission Form and Research Protocol I have approved your proposed research ("Measuring Factors that Influence the Success of E-government Initiatives") for IRB purposes (IRB approval number: cannady0515058). Your research has been determined to be exempt from further IRB review based on the following conclusion:

Research using survey procedures or interview procedures where subjects' identities are thoroughly protected and their answers do not subject them to criminal and civil liability.

Please note that while your research has been approved, additional IRB reviews of your research will be required if any of the following circumstances occur:

1. If you, during the course of conducting your research, revise the research protocol (e.g., making changes to the informed consent form, survey instruments used, or number and nature of subjects).

2. If the portion of your research involving human subjects exceeds 12 months in duration.

Please feel free to contact me in the future if you have any questions regarding my evaluation of your research or the IRB process.

Copy:

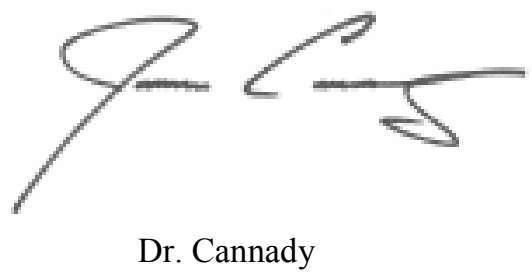

Dr. Nyshadham

File 


\section{Appendix G}

\section{Survey Instrument Sample Screen}

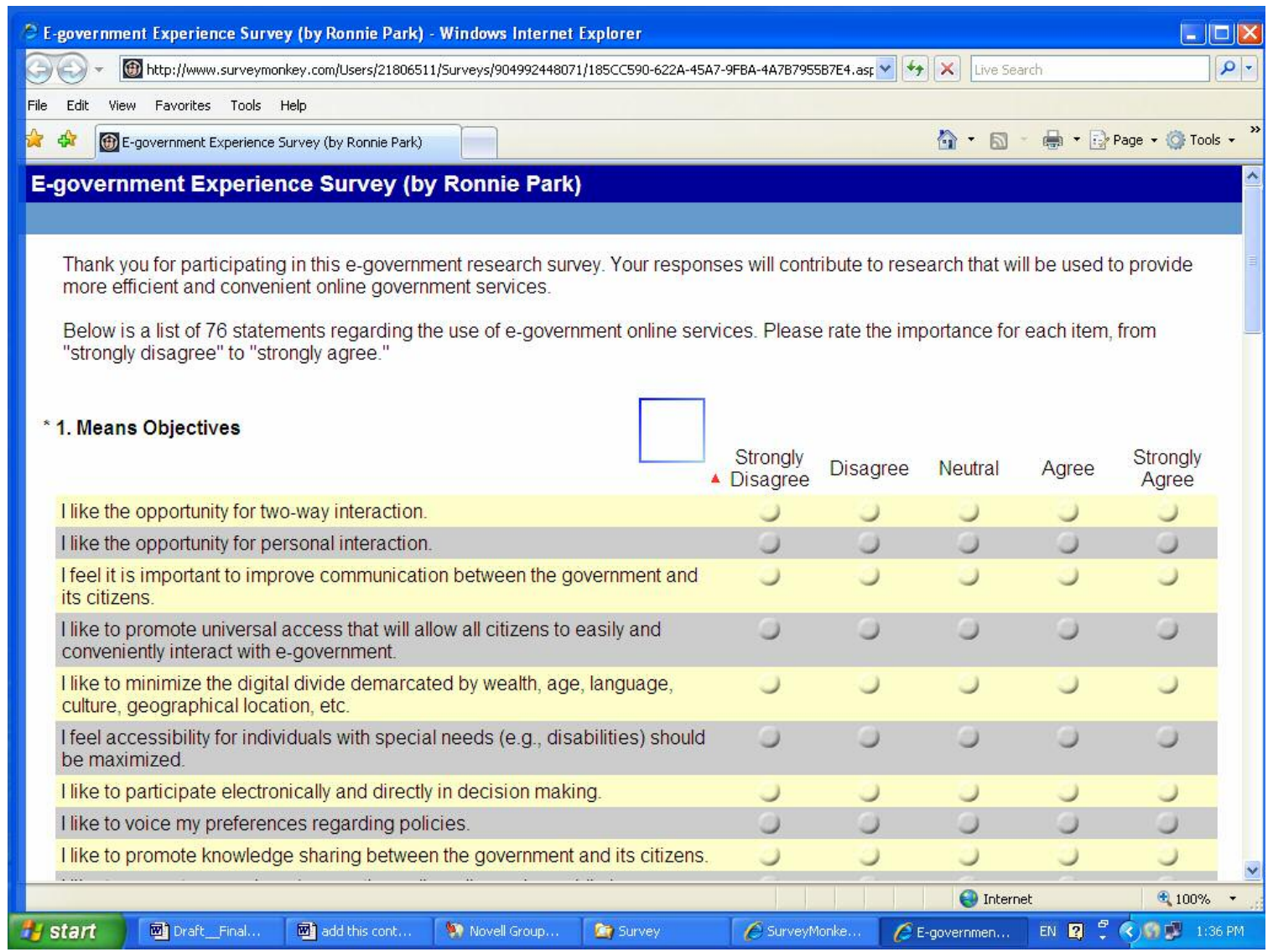

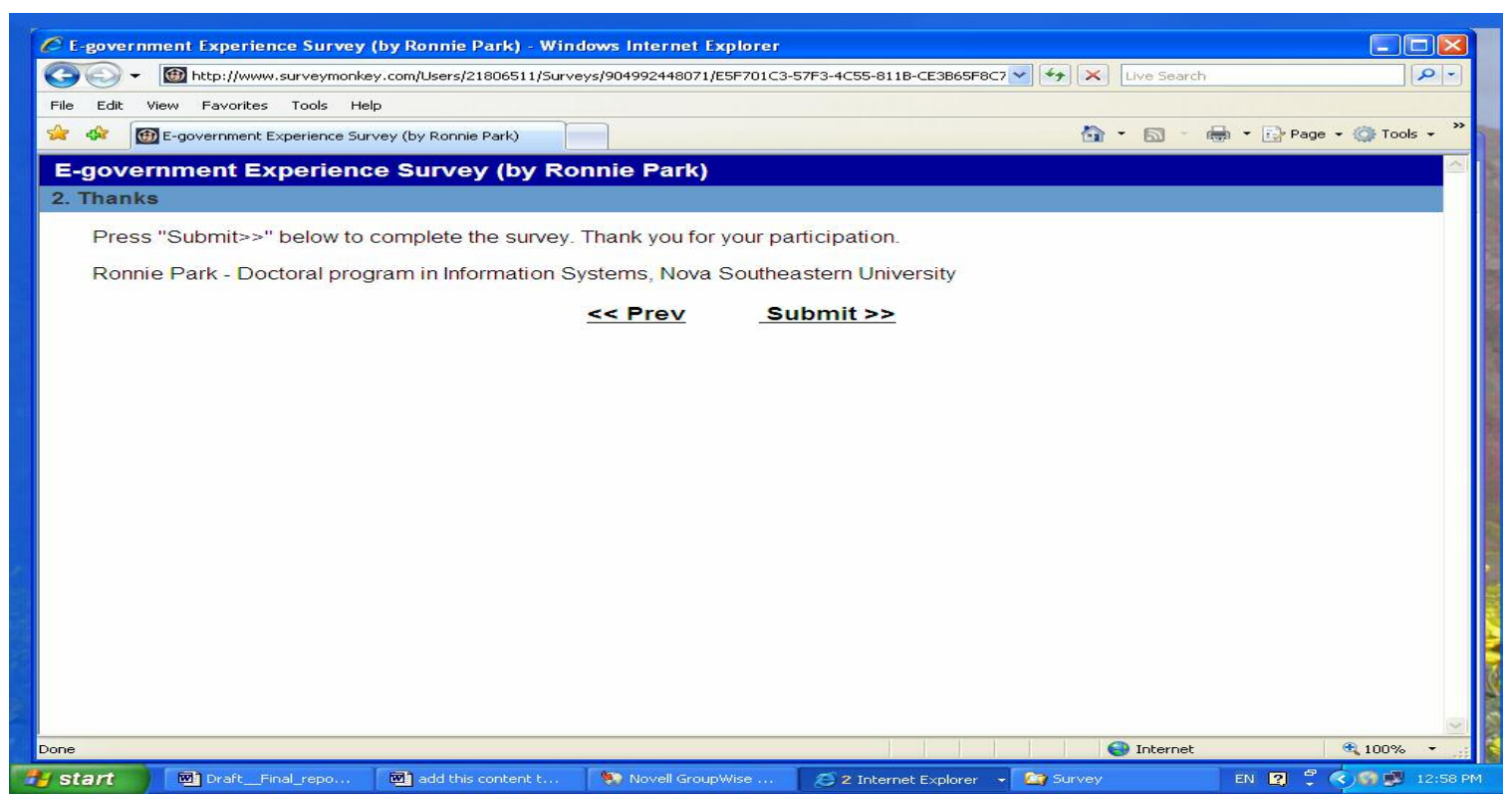




\section{References}

Aichholzer, G., \& Schmitzer, R. (2000). Organizational challenges to the development of electronic government. Proceedings from $11^{\text {th }}$ International Workshop on Database and Expert Systems Applications, London, England, 379-383.

Aichholzer, G., \& Sperlich, R. (2001). Electronic government services for the business sector in Austria. Proceedings from $12^{\text {th }}$ International Workshop on Database and Expert Systems Applications, Munich, Germany, 402-406.

Bailey, J., \& Pearson, W. (1983). Development of a tool for measuring and analyzing computer user satisfaction. Management Science, 29(5), 530-545.

Balutis, A. P. (2001A). E-government 2001, part I: understanding the challenge and evolving strategies. The Public Manager, 30(1), 33-41.

Balutis, A. P. (2001B). E-government 2001, part II: evolving strategies for action. The Public Manager, 30(2), 41-48.

Bertot, J. C., McClure, C. R., Moen, W. E., \& Rubin, J. (1997). Web usage statistics: measurement issues and analytical techniques. Government Information Quarterly, 14(4), 373-396.

Bichler, M. (2000). An experimental analysis of multi-attribute auction. Decision Support Systems, 29(3), 249--268.

Bretschneider, S. (2003). Information technology, e-government, and institutional change. Public Administration Review, 63(6), 738-741.

Camerer, C. F. (1997). Progress in behavioral game theory. Journal of Economic Perspectives, 11(4), 167-188.

Camerer, C. F., Ho, T., \& Chong J. K. (2001). Behavioral game theory: thinking, learning, and teaching. Retrieved August 3, 2005, from California Institute of Technology Web site: http://www.hss.caltech.edu/ camerer/Camerer.pdf

Cameron, K. S., \& Whetten, D. A. (1983). Some conclusions about organizational effectiveness. In K. S. Cameron, and D. A. Whetten, (Eds.), Organizational Effectiveness: A Comparison of Multiple Models (pp.261-277). New York: Academic Press.

Carter, L., \& Belanger, F. (2004). Citizen adoption of electronic government initiatives. Proceedings of the 37th Hawaii International Conference on Systems Sciences, 50119a, 1-10. Honolulu, HI. 
Carter, L., \& Belanger, F. (2005). The utilization of e-government services: citizen trust, innovation and acceptance factors. Information Systems Journal, 15(1), 5-25.

Chang, J., Torkzadeh, G., \& Dhillon, G. (2004). Re-examining the measurement models of success for Internet commerce. Information \& Management, 41(4), 577-584.

Chen, H., Chen, Y., Huang, W., \& Ching, R. (2006). E-government strategies in developed and developing countries: an implementation framework and case study. Journal of Global Information Management, 14(1), 23-24.

Chen, H. (2002). Digital government: technologies and practices. Decision Support Systems, 34(2002), 223-227.

Clark, E. (2003). Managing the transformation to e-government: an Australian perspective. Thunderbird International Business Review, 45(4), 377- 397.

Council for Excellence in Government (2001). E-government: the next American resolution. Washington, DC: Author.

Courtois, M. P., \& Berry, M. W. (1999). Results ranking in Web search engines. Online, 23(3), 39-44.

Csetenyi, A. (2000). Electronic government: Perspectives from E-commerce. Proceedings of the $11^{\text {th }}$ International Workshop on Database and Expect Systems Applications, 294-299. London, U.K.

Dawes, S. S., Pardo, T. A., \& Cresswell, A. M. (2003). Designing government information access programs: a holistic approach. Proceedings of the 36th Hawaii International Conference on Systems Sciences, Big Island, HI.

Dearstyne, B. W. (Oct. 2001). E-business, e-government \& information proficiency. The Information Management Journal, 16-24.

Devadoss, P. R., Pan, S. L., \& Huang, J. C. (2002). Structurational analysis of egovernment initiatives: a case study of SCO. Decision Support Systems. 34(3), 253-269.

Devellis, D. F. (2003). Scale Development: Theory and Applications. Thousand Oaks, CA: Sage Publications.

Dhillon, G., \& Lee, J. (2000). Value assessment of IS/IT service provision within organizations. Proceeding of the Twenty First International Conference on Information Systems, Las Vegas, NV.

Doctor, R., \& Ankem, K. (March, 1996). An information need and services taxonomy: For evaluating Computerized Community Information Systems. Presented at Community Networking 96: "Bringing People Together". Retrieved February 6, 2003 from http://www.laplaza.org/about_lap/archives/cn96/doctor1.html. 
Einhorn, H. J., \& Hogarth, R. M. (1981). Behavioral decision theory: processes of judgment and choice, Journal of Accounting Research, 19(1), 1031.

Elmagarmid, A. K., \& McIver, W. J. (February, 2001). The ongoing march toward digital government. Computer, 32-38.

Fisk, R. P., Brown, S. W., \& Bitner, M. J. (1993). Tracking the evolution of the services marketing literature. Journal of Retailing, 69(1), 61-103.

French, S. (2003). The challenges of extending the MCDA paradigm to e-democracy. Journal of Multi-Criteria Decision Analysis, 12, 63-64.

Fu, J., Farn, C., \& Chao, W. (2006). Acceptance of electronic tax filing: a study of taxpayer intentions. Information \& Management, 43(1), 109-126.

Fugini, M., \& Mezzanzanica, A. (2004). An application within the plan for egovernment: the workfare portal. University of Milano, Italy. Idea Group Inc. 59-80.

Gartner (March, 2002). The Gartner framework for e-government strategy assessment. New York: Gartner.

Gorden, T. F. (2002). E-government -Introduction. ERCIM News, Special Theme: Egovernment, European Research Consortium for Information and Mathematics. Retrieved on March 4, 2005, from http://www.ercim.org/publication/Ercim_News/enw48/intro.html.

Grant, G., \& Chau, D. (2005). Developing a generic framework for e-government. Journal of Global Information Management, 13(1), 1-30.

Gronlund, A. (2003). Emerging electronic infrastructures: exploring democratic components. Social Science Computer Review, 21(1), 55-72.

Grover, V., Keong, S. R., \& Segars, A. H. (1996). Information systems effectiveness: the construct space and patterns of application. Information \& Management, 31(2), 177-191.

Gupta, M. P., \& Jana, D. (2003). E-government evaluation: a framework and case study. Government Information Quarterly, 20(3), 365-387.

Hair, J., Anderson, R., Tatham, R., \& Black, W. (1998). Multivariate Data Analysis. Upper Saddle River, NJ: Prentice Hall.

Holden, S. H., Norris, D. F., \& Fletcher, P. D. (2003). Electronic government at the grass roots: contemporary evidence and future trends. Proceedings of the 38th Hawaii International Conference on Systems Sciences, Honolulu, HI. 
Howard, R. (1988). Decision analysis: Practice and promise. Management Science, 34(6), 679-695.

Jain, A., \& Patnayakuni, R. (2003). Public expectations and public scrutiny: an agenda for research in the context of e-government. Ninth Americas Conference on Information Systems, 811-820. Tempa, FL.

Jorgensen D., \& Cable S. (2002). Facing the challenges of e-government: a case study of the city of Corpus Christi, Texas. S.A.M. Advanced Management Journal, 67(1), 34-45.

Kahneman, D., \& Tversky, A. (1979). Prospect theory: an analysis of decision under risk. Econometrica, 47(2), 263-291.

Kalakota, R., \& Whinston, A. B. (1997). Electronic Commerce. Reading, MA: AddisonWesley.

Kamakura, W. A., \& Mazzon, J. A. (1991). Value segmentation: a model for the measurement of values and value systems, The Journal of Consumer Research, 18(2), $208-218$

Kappelman, L. A., Koh, C. E., Prybutok, V. R., \& Sanchez, A. D. (2003). The relationship between IT for communication and e-government barriers. Ninth Americas Conference on Information Systems, Tempa, FL.

Kaylor, C., Deshazo, R., \& Eck, D. (2001). Gauging e-government: a report on implementing services among American cities. Government Information Quarterly, 18(4), 293-307.

Keeney, R. L. (1992). Value-Focused Thinking: A Path to Creative Decision Making. Cambridge, MA: Harvard University Press.

Keeney, R. L. (1999). The value of Internet commerce to the customer. Management Science, 45(4), 533-542.

Keeney, R.L., \& Raiffa, H (1993). Decisions with Multiple Objectives: Preferences and Value Tradeoffs. Cambridge, England: Cambridge University Press.

Kim, H. J., \& Bretschneider, S. (2004). Local government information technology capacity: an exploratory theory. Proceedings of the 37th Hawaii International Conference on Systems Sciences, 50121b, 1-9. Honolulu, HI.

Kim, J., \& Mueller, C. (1978). Introduction to Factor Analysis. Newbury Park, CA: Sage Publications. 
King, D., Lee, J., Warkentin, M., \& Chung, H. M. (2002). Electronic Commerce a Managerial Perspective. Upper Saddle River, NJ: Prentice Hall.

Langer, G. (2003). About response rates. Public Perspective. Retrieved January 2, 2006, from the University of Connecticut Web site: http://www.ropercenter.uconn.edu/pubper/pdf/pp14_3c.pdf.

Layne, K., \& Lee, J. (2001). Developing fully functional e-government: a four-stage model. Government Information Quarterly, 18(2), 122-136.

Lenk, K. (2002). Electronic service delivery - a driver of public sector modernization. Information Polity 7, 87-96.

Lenk, K., \& Traunmuller, R. (2000). A framework for electronic government. Proceedings of the $11^{\text {th }}$ International Workshop on Database and Expert systems Applications, London, UK.

Ma, L., Chung, J., \& Thorson, S. (2005). E-government in China: bringing economic development through administrative reform. Government Information Quarterly, 22(2), 20-37.

Marchionini, G., Samet, H., \& Brandt, L. (2003). Digital government. Communications of the ACM, 46(1), 25-27.

McGinnis, P. (Summer, 2003). Innovation in American e-government: FirstGov. gov. The Public Manager, 51- 54.

McNeal, R. S., Tolbert, C. J., Mossberger, K., \& Dotterweich, L. J. (2003). Innovating in digital government in the American states. Social Science Quarterly, 84(1), 52-70.

Medjahed, B., Rezgui, A., Bouguettaya, A., \& Ouzzani, M. (Jan/Feb, 2003).

Infrastructure for e-government Web services. IEEE Internet Computing, 58-65.

Melitski, J. (2003). Capacity and e-government performance. Public Performance \& Management Review, 26(4), 376-390.

Mittal, P., Kumar, M., Mohania, M., Nair, M., Batra, N., Roy, P., Saronwala, A., \& Yagnik, L. (2004). A framework for eGovernance solutions. IBM Journal of Research and Development, 48(5/6), 717-733.

Moon, M. (Jul/Aug, 2002). The evolution of e-government among municipalities: rhetoric or reality? Public Administration Review, 62(4), 424-433.

Moon, M. J., \& Welch, E. W. (2004). Same bed, different dreams?: a comparative analysis of citizen and bureaucrat perspectives on e-government. Proceedings of the $37^{\text {th }}$ Hawaii International Conference on Systems Sciences, Honolulu, HI. 
Muir, A., \& Oppenheim, C. (2002). National information policy developments worldwide I: electronic government. Journal of Information Science, 28(3), 173-186.

Nah, F., Siau, K., \& Sheng, H. (2005). The value of mobile applications: a utility company study. Communications of the ACM, 48(2), 85-92.

National Academy of Sciences (2002). Information Technology, Research, Innovation and E-government, Washington, DC: National Academy Press.

National Computerization Agency (2002). E-government in Korea. Seoul, Republic of Korea.

Navarra, D. D., \& Cornford, T. (2003). A policy making view of e-government innovations in public governance. Ninth Americas Conference on Information Systems, Tempa, FL.

Norrise, D. F., \& Moon, M. J. (2005). Advancing e-government at the grassroots: tortoise or hare? Public Administration 65(1), 64-75.

Nova Southern University, Graduate School of Computer and Information Sciences (February, 2005). IRB process overview. Retrieved July 10, 2005, from the Nova Southeastern University Web site: http://www.scis.nova.edu/\%7Ecannady/IRB_Info.htm

Office of the e-Envoy (2000). Modernizing government: Benchmarking electronic service delivery. Retrieved March 2, 2004, from the United Kingdom government sponsored Web site: http://egov.alentejodigital.pt/Benchmarks/BenchmarkingESD.pdf.

Ohison, D. W. (1999). Exploring the application of adaptive management and decision analysis to integrated waterahed management. Retrieved December 10, 2004, from University of British Columbia, Canada, http://www.scarp.ubc.ca/thesis/ohlson/framework2.htm

Pandy, S. (Fall, 2002). Expanding electronic government: The challenges. The Public Manager, 31(3), 17-21.

Peters, R., Jansen, M., \& Engers, T. (2004). Measuring e-government impact: existing pratices. Sixth International Conference on Electronic Commerce, 480-488. Delft, Netherlands

Pons, A. (2004). E-government for Arab countries. Journal of Global Information Technology Management, 7(1), 30-47.

Prattipati, S. N. (2003). Adoption of e-governance: differences between countries in the use of online government services. Journal of American Academy of Business, 3(1/2), 386-391. 
Raiffa, H. (1968). Decision Analysis: Introductory Lectures on Choices Under Uncertainty. Reading, MA: Addison-Wesley Publishing Company.

Rennie, L. (1982). Detecting a response set to Likert-style attitude items with the rating model. Education Research and Perspectives, 9(1), 114-118. Retrieved January 2, 2006, from the University of Western Australia Web site: http://www.rasch.org/erp9.htm.

Robin, M. (1998). Psychology and economics, Journal of Economic Literature, 36(1), 11-46.

Rokeach, M. (1974). Change and stability in American value systems, 1968-1971. The Public Opinion Quarterly, 38(2), 222-238.

Roy, J. (2003). Introduction e-government. Social Science Computer Review, 21(1), 3-5.

Rummel, R. (1970). Understanding factor analysis. Retrieved October 14, 2005 from the University of Hawaii Web site: http://www.hawaii.edu/powerkills/UFA.HTM

Scherlis, W. L., \& Eisenberg, J. (2003). IT research, innovation, and e-government. Communications of the ACM, 46(1), 67-68.

Schubert, P., \& Hausler, U. (2001). E-government meets e-business: a portal site for startup companies in Switzerland. Proceedings of the $34^{\text {th }}$ Hawaii International Conference on System Sciences. Big Island, HI.

Sekaran, U. (2000). Research Methods for Business. New York: John Wiley \& Sons, Inc.

Shackleton, P., Fisher, J., \& Dawson, L. (2004). Evolution of local government eservices: the applicability of e-business maturity models. Proceedings of the $37^{\text {th }}$ Hawaii International Conference on System Sciences. Big Island, HI.

Spradlin, T. (2005). A lexicon of decision making. Decision Analysis Society. Retrieved December 21, 2005, from the Duke University Web site: http://faculty.fuqua.duke.edu/daweb/lexicon.htm\#decision_analysis

Steyaert, J. C. (2004). Measuring the performance of electronic government services. Information \& Management, 41(3), 369-375.

Stowers, G. (2002). The State of Federal Web Sites: The Pursuit of Excellence (Egovernment Series). San Francisco: San Francisco State University.

Straub, D. (1989). Validating instruments in MIS research. MIS Quarterly, 13(2), 147170.

Strejcek, G., \& Theil, M. (2002). Technology push, legislation pull? E-government in the European Union. Decision Support Systems, 34(2002), 305-313. 
Swartz, N. (2004). E-government around the world. Information Management Journal, $38(1), 12-15$.

Teo, T., \& Pian, Y. (2004). A model for Web adoption. Information \& Management, 4l(5), 457-468.

Thaler, R. H. (1986). The psychology and economics conference handbook: comments on Simon, on Einhorn and Hogarth, and on Tversky and Kahneman, The Journal of Business, 59(4), 279-824.

Thaler, R. H. (1987). Anomalies: The January effect. The Journal of Economic Perspectives, 1(1), 197-201.

Thomas, J. C., \& Streib, G. (2003). The new face of government: citizen-initiated contacts in the era of e-government. Journal of Public Administration Research and Theory, 13(1), 83-102.

Torkzadeh, G., \& Dhillon, G. (2002). Measuring factors that influence the success of Internet commerce. Information Systems Research, 13(2), 187-204.

United Nations (2002). Benchmarking e-government: A global perspective. United Nations Division for Public Economics and Public Administration. New York: United Nations.

U.S. Federal government (1999). Electronic government. Memorandum to the Heads of Executive Departments and Agencies. Retrieved on January 21, 2004, from $\mathrm{http} / /$ govinfo.library.unt.edu/npr/library/direct/memos/elecgovrnmnt.html.

U.S. Office of Management and Budget (2002). E-government strategy: Simplified delivery of services to citizens. Washington, DC: U.S. Government Printing Office.

Vetenskapsakademien, K. (December, 2002). Foundations of behavioral and experimental economics: Daniel Kahneman and Vernon Smith. Retrieved August 2, 2005, from the Advanced information on the Prize in Economic Sciences Web site: http://nobelprize.org/economics/laureates/2002/ecoadv02.pdf

Vriens, D., \& Achterbergh, J. (2004). Planning local e-government. Information Systems Management, 21(1), 45-57.

Wagner, C. (2003). Knowledge management in e-government. Ninth Americans Conference on Information Systems, 845-850. Tempa, FL.

Wert, J. M. (2002). E-government and performance: a citizen-centered imperative. The Public Manager, 31(2), 16-21. 
West, D. M. (2004). E-government and the transformation of service delivery and citizen attitudes. Public Administration Review, 64(1), 15-26.

Wimmer, M., \& Traunmuller, R. (2000). Trends in electronic government: managing distributed knowledge. Proceedings of the $11^{\text {th }}$ International Workshop on Database and Expert systems Applications, London, UK.

Winterfeldt, D., \& Edwards, W. (1986). Decision Analysis and Behavioral Research. Cambridge, England: Cambridge University Press.

Yu, L., Wang, S., \& Lai, K. (2006). An integrated data preparation scheme for neural network data analysis. IEEE Transactions on Knowledge and Data Engineering, 18(2), 217-230. 